VILNIAUS GEDIMINO TECHNIKOS UNIVERSITETAS

Vladislav MARKOVIČ

\title{
DAUGIAFUNKCIŲ PAVIRŠIŲ IŠ GELEŽIES-NIKELIO-KOBALTO MILTELINIŲ MEDŽIAGŲ FORMAVIMAS IR TYRIMAS
}

DAKTARO DISERTACIJA

TECHNOLOGIJOS MOKSLAI, MEDŽIAGŲ INŽINERIJA (08T)

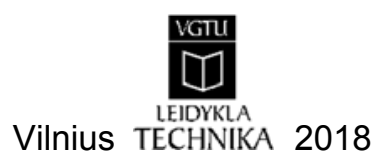


Disertacija rengta 2012-2018 metais Vilniaus Gedimino technikos universitete.

Vadovas

doc. dr. Olegas ČERNAŠĖJUS (Vilniaus Gedimino technikos universitetas, medžiagų inžinerija - 08T).

Vilniaus Gedimino technikos universiteto Medžiagų inžinerijos mokslo krypties disertacijos gynimo taryba:

\section{Pirmininkas}

dr. Viktor GRIBNIAK (Vilniaus Gedimino technikos universitetas, medžiagų inžinerija - 08T).

\section{Nariai:}

dr. Justinas GARGASAS (Vilniaus Gedimino technikos universitetas, medžiagu inžinerija - 08T),

dr. Rasa KANDROTAITÉ JANUTIENE (Kauno technologijos universitetas, medžiagų inžinerija - 08T),

habil. dr. Jaroslaw KONIECZNY (Silezijos technologijos universitetas, medžiagų inžinerija - 08T),

prof. dr. Vytautas TURLA (Vilniaus Gedimino technikos universitetas, mechanikos inžinerija - 09T).

Disertacija bus ginama viešame Medžiagų inžinerijos mokslo krypties disertacijos gynimo tarybos posėdyje 2018 m. rugpjüčio 29 d. 14 val. Vilniaus Gedimino technikos universiteto senato posèdžių salëje.

Adresas: Sauletekio al. 11, LT-10223 Vilnius, Lietuva.

Tel.: (8 5) 274 4956; faksas (8 5) 270 0112; el. paštas doktor@vgtu.lt

Pranešimai apie numatomą ginti disertaciją išsiųsti $2018 \mathrm{~m}$. liepos $27 \mathrm{~d}$.

Disertaciją galima peržiūrèti VGTU talpykloje http://dspace.vgtu.lt ir Vilniaus Gedimino technikos universiteto bibliotekoje (Saulètekio al. 14, LT-10223 Vilnius, Lietuva).

VGTU leidyklos TECHNIKA 2018-036-M mokslo literatūros knyga

http://leidykla.vgtu.lt

ISBN 978-609-476-122-5

(C) VGTU leidykla TECHNIKA, 2018

(C) Vladislav Markovič, 2018

vladislavmarkowic@gmail.com 
VILNIUS GEDIMINAS TECHNICAL UNIVERSITY

Vladislav MARKOVIČ

\section{THE FORMATION AND INVESTIGATION OF MULTIFUNCTIONAL SURFACES FROM IRON-NICKEL-COBALT POWDER MATERIALS}

DOCTORAL DISSERTATION

TECHNOLOGICAL SCIENCES,

MATERIALS ENGINEERING (08T)

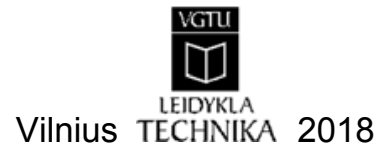


Doctoral dissertation was prepared at Vilnius Gediminas Technical University in 2012-2018.

\section{Supervisor}

Assoc. Prof. Dr Olegas ČERNAŠ́̇JUS (Vilnius Gediminas Technical University, Materials Engineering - 08T).

The Dissertation Defence Council of Scientific Field of Materials Engineering of Vilnius Gediminas Technical University:

\section{Chairman}

Dr Viktor GRIBNIAK (Vilnius Gediminas Technical University, Materials Engineering - 08T).

\section{Members:}

Dr Justinas GARGASAS (Vilnius Gediminas Technical University, Materials Engineering - 08T),

Dr Rasa KANDROTAITÉ JANUTIENE (Kaunas University of Technology, Materials Engineering - 08T),

Dr Habil. Jaroslaw KONIECZNY (Silesian University of Technology, Materials Engineering - 08T),

Prof. Dr Vytautas TURLA (Vilnius Gediminas Technical University, Mechanical Engineering - 09T).

The dissertation will be defended at the public meeting of the Dissertation Defence Council of Materials Engineering in the Senate Hall of Vilnius Gediminas Technical University at 2 p. m. on 29 August 2018.

Address: Saulètekio al. 11, LT-10223 Vilnius, Lithuania. Tel.: +370 5274 4956; fax +370 5270 0112; e-mail: doktor@vgtu.lt

A notification on the intend defending of the dissertation was send on 27 July 2018.

A copy of the doctoral dissertation is available for review at VGTU repository http://dspace.vgtu.lt and at the Library of Vilnius Gediminas Technical University (Saulètekio al. 14, LT-10223 Vilnius, Lithuania). 


\section{Reziumè}

Disertacijoje nagrinejjami selektyviuoju lazerinio sukepinimo (SLS) būdu iš FeNi-Co pagrindo miltelių gauti sukepintieji gaminiai, skirti naudoti ịvairiose pramonès šakose (pvz., polimeru liejimo formų gamyboje ir kt.) esant sunkioms darbo sąlygoms. Jų eksploatacinèms savybèms pagerinti pasiūlytas sukepintų paviršių lazerinis mikroapdorojimas. Lazerinis mikroapdorojimas - tai lazerinio apdorojimo procesas, kurio poveikis apdorojamam paviršiui vertinamas mikroskaleje. Disertacijos tikslas - sukurti ir ištirti daugiafunkci, miltelinio pagrindo paviršių ir nustatyti priklausomybę tarp lazerinio apdorojimo koncentruotosios energijos pluošto technologinių parametru pokyčio ir apdorojamo paviršiaus kokybinių charakteristikų. Tyrimais siekiama pagerinti sukepinto paviršiaus eksploatacines savybes bei suteikti jam naujų kokybinių charakteristikų. Papildomas SLS būdu sukepinto paviršiaus lazerinis apdorojimas leis taupyti gamybos laiką ir ekonominius išteklius dèl sumažèjusio technologinių operacijų kiekio, lyginant su tradiciniais SLS būdu sukepintų paviršių apdorojimo būdais.

Disertaciją sudaro ịvadas, trys skyriai, bendrosios išvados, literatūros ir autoriaus publikacijų disertacijos tema sąrašai bei penki priedai. Ivadiniame skyriuje aptariama tiriamoji problema, darbo aktualumas, aprašomas tyrimų objektas, formuluojamas darbo tikslas bei uždaviniai, aprašoma tyrimų metodika, darbo mokslinis naujumas, darbo rezultatu praktinè reikšmė, ginamieji teiginiai. Ivado pabaigoje pristatomos disertacijos tema autoriaus paskelbtos publikacijos ir pranešimai konferencijose bei disertacijos struktūra. Pirmajame skyriuje apžvelgiami adityviosios gamybos ypatumai, sukepinimo technologijos fizikiniai principai ir taikymo sritys, sukepintu gaminių apdorojimas tradiciniais ir inovatyviais būdais, sukepintų paviršių modifikavimo metodai. Skyriaus pabaigoje formuluojamos išvados ir tikslinami disertacijos uždaviniai. Antrajame skyriuje aprašomos darbe naudotos žaliavos ir ịrenginiai, darbe taikomi medžiagų ir jų savybių tyrimo metodai. Trečiajame skyriuje pateikiami ir analizuojami sukepintų bei modifikuotu gaminių sandaros tyrimų rezultatai, neapdorotų ir apdorotų paviršių mikrostruktūros, morfologijos ir topografijos tyrimai, modifikuotų paviršių mikrokietumo, atsparumo dilimui ir korozijai tyrimų rezultatai.

Disertacijos tema paskelbti 8 straipsniai, o tyrimų rezultatai pristatyti 10 mokslinių konferencijų Lietuvoje ir užsienyje. 


\section{Abstract}

In the thesis, sintered products formed from Fe-Ni-Co powder base using selective laser sintering that are used in variuos indoustries (for example in production of plastic injection tools) in severe working conditions are investigated. Laser microprocessing was used to improve performance and multifuncionality of the sintered surfaces. Laser microprocessing - is a laser machining process, where laser impact is measured in microscale. The aim of the dissertation is to investigate and create a multifunctional powder base surface and to determine the relationship between the change in the technological parameters of the laser beam microprocessing and the qualitative characteristics of the treated surface. The goal is to improve the performance of the sintered surface and give it new quality characteristics. It will help to save production time and economical resources.

The thesis includes the introduction, three chapters, the general conclusions, the list of reference, the list of publications of the author and five annexes. In the introduction, the problem under the investigation and the topicality of the work are discussed upon, the object of the investigation is described, the aim and the tasks of the work are formulated, the research methods, the scientific novelty of the work, the practical significance of its results and the defended statement are described. In the end of the introduction, publications of the author and his reports at conference on the subject of the thesis as well as the structure of the thesis are presented. In the Chapter 1, features of additive production, physical principles and application of sintering technology, processing of sintered products by traditional and innovative methods, methods for modifying sintered surfaces are reviewed. At the end of the chapter conclusions are formulated and the tasks of the dissertation are revised. In the Chapter 2, the equipment and raw material used in the work and its properties and applied research methods are described. In the Chapter 3, structure analysis of the sintered and modified products, microstructures of the processed and non processed surfaces, morphology and topographics analysis, microhardness, wear and corrosion resistance analysis results are presented and discussed. Materials of the thesis have been published in eight scientific publications and presented at 10 scientific conferences held in Lithuania and abroad. 


\section{Žymenys}

\section{Simboliai}

E - iqvedamosios energijos lygmuo, $\mathrm{W} / \mathrm{cm}^{2}$;

d - lazerio spindulio pluošto dèmès plotas bandinio paviršiuje, $\mathrm{mm}^{2}$;

$E_{i}$ - vieno impulso energija, J;

$E_{i t}-$ impulso energijos tankis, $\mathrm{J} / \mathrm{cm}^{2}$;

$\mathrm{E}_{\text {its }}$ - energijos kiekis apdorojimo paviršiuje per vieną sekundę, $\mathrm{W} / \mathrm{cm}^{2}$;

$\mathrm{n}$ - mikrolazerinio apdorojimo èjimų skaičius;

$\mathrm{P}$ - mikrolazerinio apdorojimo galia, $\mathrm{W}$;

$\mathrm{v}$ - mikrolazerinio apdorojimo greitis, $\mathrm{mm} / \mathrm{s}$;

$\mathrm{v}^{\prime}-$ mikrolazerinio apdorojimo atskaitos greitis, $\mathrm{mm} / \mathrm{s}$;

$\mathrm{Z}$ - apdorojimo ir atskaitos greičių santykis;

$v$ - impulsų generavimo dažnis, Hz;

$\lambda$ - spinduliuotès bangos ilgis, $\mathrm{nm}$;

$\tau$ - impulso trukmè, ns;

\section{Santrumpos}

A1-A12 - A eksperimento bandinių žymenys;

AG - adityvioji gamyba;

B1-B3 - B eksperimento bandinių žymenys;

C1-C12 - C eksperimento bandinių žymenys;

D1-D14 - D eksperimento bandinių žymenys; 
KCT - kubinè, centruoto tūrio gardelè;

$\mathrm{N}$ - neapdorotas bandinys;

SLS - selektyvusis lazerinis sukepinimas;

viii 


\section{Turinys}

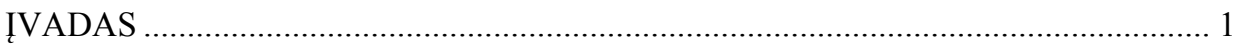

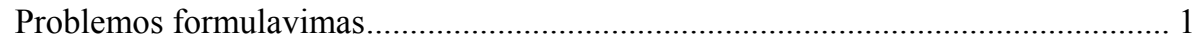

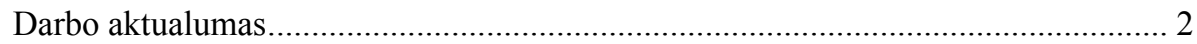

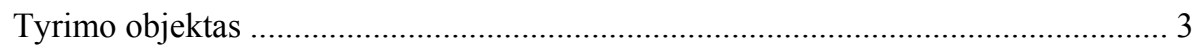

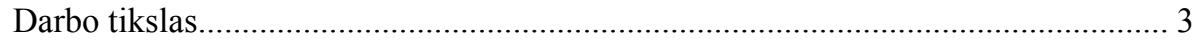

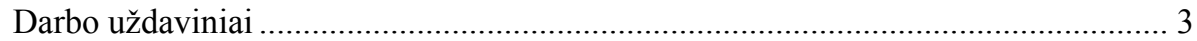

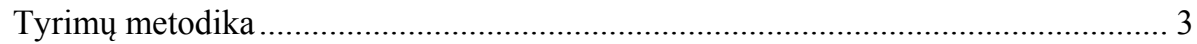

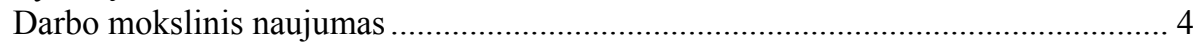

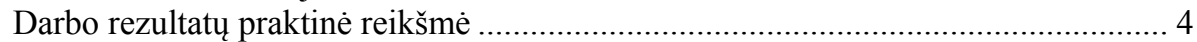

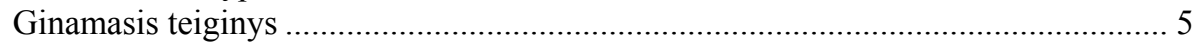

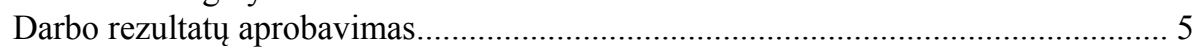

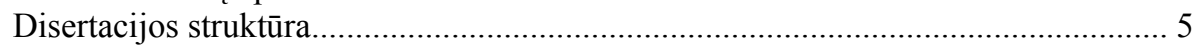

1. ADITYVIOSIOS GAMYBOS IR METALINIŲ PAVIRŠIŲ MODIFIKAVIMO YPATUMŲ ANALIZĖ.......................................................................................... 7

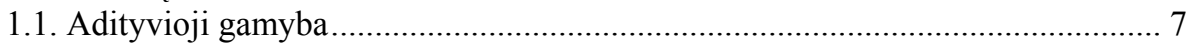

1.1.1. Adityviosios gamybos plètra ................................................................. 7

1.1.2. Selektyvusis lazerinis sukepinimas .......................................................... 9

1.2. Tradicinių metalinių paviršių apdorojimo būdų apžvalga ................................ 11

1.3. Inovatyviujų metalinių paviršių apdorojimo būdų apžvalga .............................. 15

1.3.1. Apdorojimas lazerio spindulio pluoštu ....................................................... 15

1.3.2. Medžiagų mikroapdorojimas lazeriu spindulio pluoštu.................................. 15

1.4. Lazerio spindulio pluošto ir inžinerinių medžiagų sąveika ............................... 20 
1.4.1. Lazerio spidulio pluošto poveikis apdirbamo metalo paviršiui

1.4.2. Faziniai virsmai lazerio spindulio veikiamo metalo paviršiuje .................... 25

1.5. Pirmojo skyriaus išvados ir disertacijos uždavinių formulavimas...................... 26

2. NAUDOTOS MEDŽIAGOS IR SUKEPINTO MILTELINIO GELEŽIES-

NIKELIO-KOBALTO PAGRINDO PAVIRŠIAUS TYRIMO METODAI ............ 29

2.1. Tyrimams naudotos medžiagos ....................................................................... 29

2.2. Selektyviojo lazerinio sukepinimo technologijos ịranga, parametrai ir

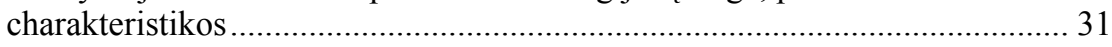

2.3. Paviršiaus modifikavimo įranga ir parametrai.................................................. 32

2.4. Technologiniai eksperimento parametrai ………............................................ 34

2.5. Eksperimentinio tyrimo metodika ……………................................................ 36

2.5.1. Optinè mikroskopija …………….......................................................... 36

2.5.2. Skenuojamoji elektroniné mikroskopija ir rentgeno mikroanalizé............ 36

2.5.3. Rentgeno spindulių difrakcijos analizè................................................... 37

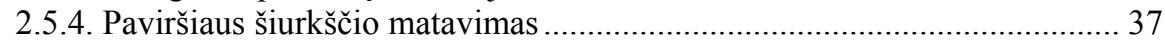

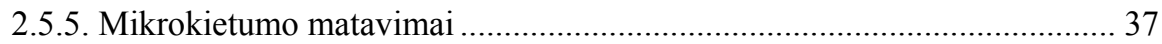

2.5.6. Tribologiniai tyrimai .............................................................................. 38

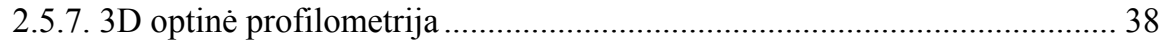

2.5.8. Korozinio atsparumo bandymai................................................................. 39

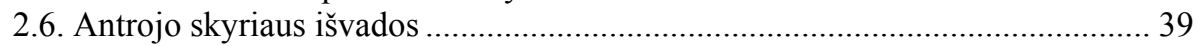

3. SUKEPINTŲ MILTELINIO PAGRINDO PAVIRŠIŲ MODIFIKAVIMO

KONCENTRUOTOSIOS ENERGIJOS ŠALTINIU PROCESO IR

EKSPLOATACINIŲ SAVYBIŲ TYRIMAI ......................................................... 41

3.1. Sukepintų ir koncentruotosios energijos šaltiniu apdorotų bandinių

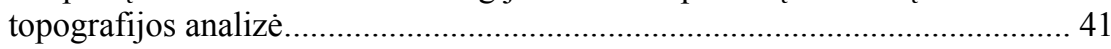

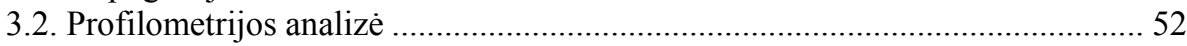

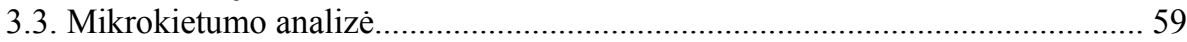

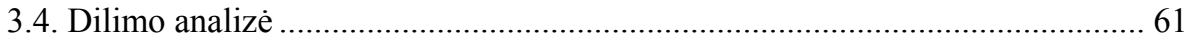

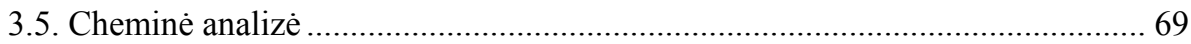

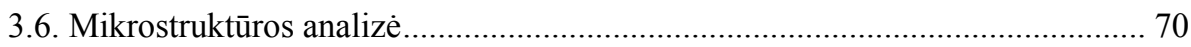

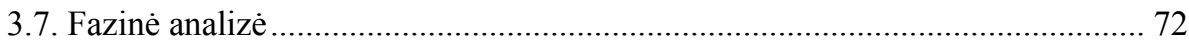

3.8. Atsparumas elektrocheminei korozijai ........................................................ 76

3.9. Trečiojo skyriaus išvados ............................................................................. 77

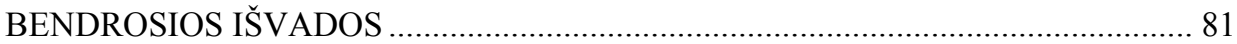

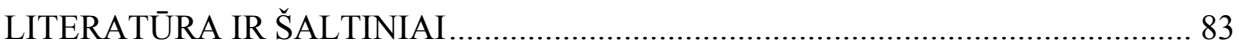

AUTORIAUS MOKSLINIŲ PUBLIKACIJŲ DISERTACIJOS TEMA SĄRAŠAS ... 91

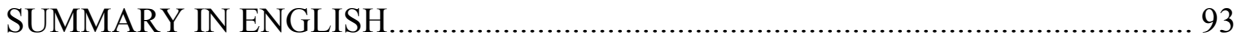


PRIEDAI $^{1}$

A priedas. Geležies lydiniams legiruoti dažniausiai naudojami legiruojantieji elementai.

B priedas. A-D eksperimentinių tyrimų technologinių parametrų reikšmès ......... 112 C priedas. Autoriaus sąžiningumo deklaracija ……………………………........ 114

D priedas. Bendraautorių sutikimai teikti publikacijų medžiagą disertacijoje ....... 115

E priedas. Autoriaus mokslinių publikacijų disertacijos tema kopijos 124

${ }^{1}$ Priedai pateikiami pridètoje kompaktinèje plokštelèje. 



\section{Contents}

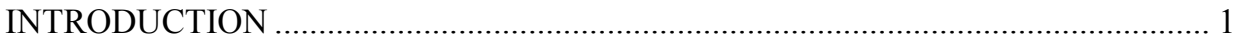

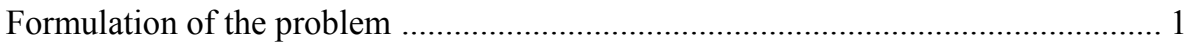

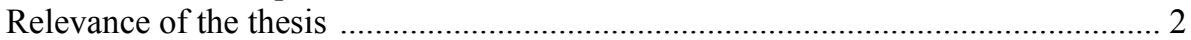

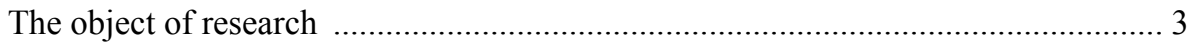

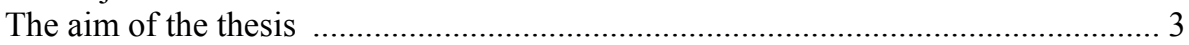

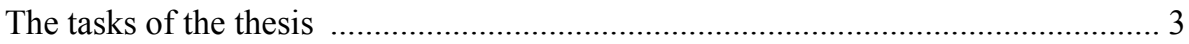

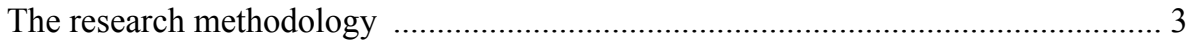

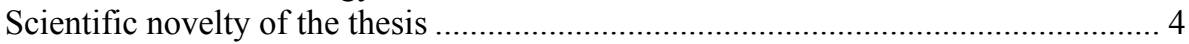

Practical value of the research findings ............................................................... 4

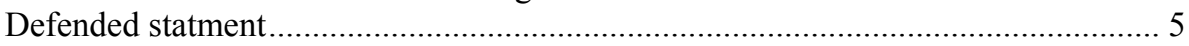

Approval of the research findings .................................................................... 5

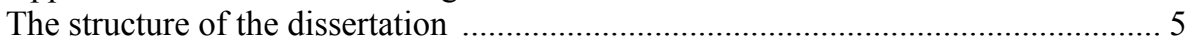

1. THE PECULIARITY ANALYSIS OF THE ADDITIVE MANUFACTURING AND MODIFICATION OF THE METALIC SURFACES ………......................... 7

1.1. Additive manufacturing............................................................................. 7

1.1.1. The development of the additive manufacturing ......................................... 7

1.1.2. Selective laser sintering .......................................................................... 9

1.2. The review of the tradicional metalic surfaces processing ways........................ 11

1.3. The review of innovative metalic surfaces processing ways............................. 15

1.3.1. Laser beam processing ....................................................................... 15

1.3.2. Laser beam microprocessig of the materials ........................................... 15

1.4. The reliationship between the laser beam and engineering materials................ 20 
1.4.1. The influence of the laser beam on the processed surface of metal

1.4.2. Phase changes of the surface metal influenced by

laser beam.

1.5. The conclusions of the first chapter and formuliation of the objectives of the thesis.

2. MATERIALS USED AND METHODS OF INVESTIGATION OF THE SINTERED SURFACE BASED ON IRON-NICKEL-COBALT POWDER.

2.1. The materials used for the investigation.

2.2. Equipment, parameters and characteristics of the selective laser sintering technology

2.3. Equipment and parameters of the surface modification ................................... 32

2.4. Technological parameters of the experiment..................................................... 34

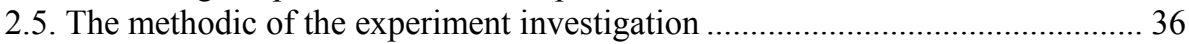

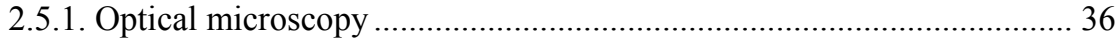

2.5.2. Scanning electron beam microscopy and X-ray microanalysis.............. 37

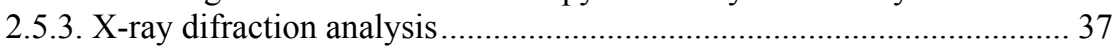

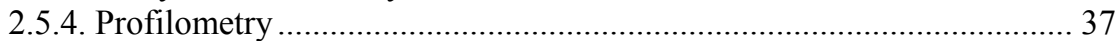

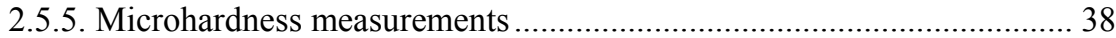

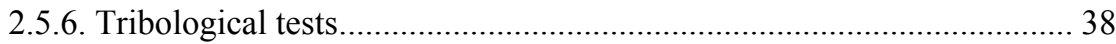

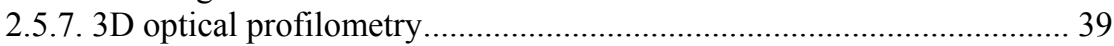

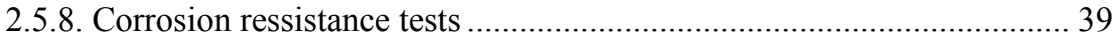

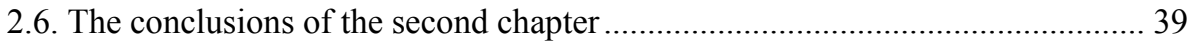

3. THE INVESTIGATION OF THE PROCESS OF MODIFAYING THE SURFACE OF SINTERED SPECIMENS BASED ON POWDER BY A CONCENTRATED ENERGY SOURCE AND THE PERFORMANCE CHARACTERSTICS OF THE

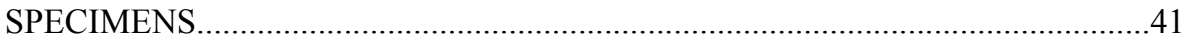

3.1. The topography analysis of the sintered and laser processed samples ............. 41

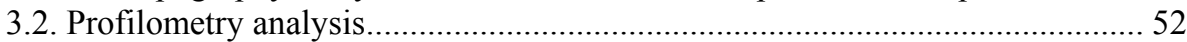

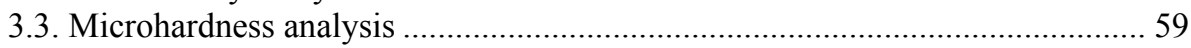

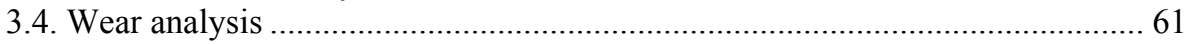

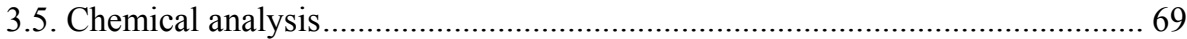

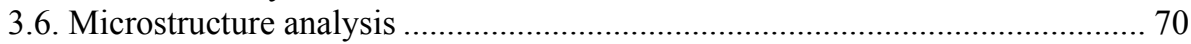

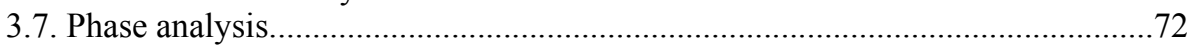

3.8. The analysis of the electrochemical corrosion resistance.................................. 76

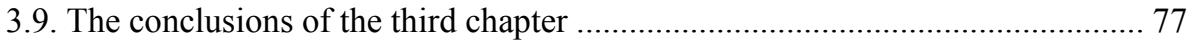

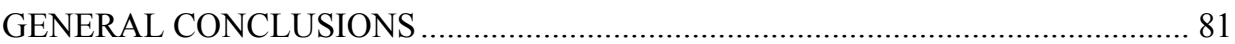

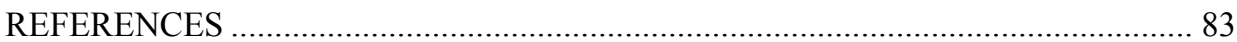

THE LIST OF SCIENTIFIC PUBLICATIONS BY THE AUTHOR ON

THE TOPIC OF THE DISSERTATION ……………….................................... 91 


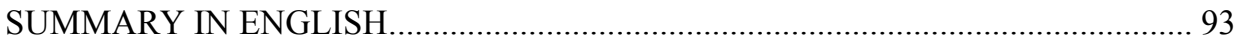

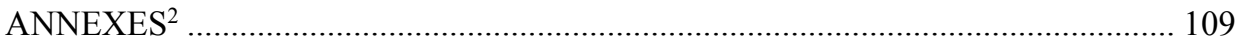

Annex A. The most used alloying ellements of the iron alloys............................. 110

Annex B. The values of the technological parameters of the experimental

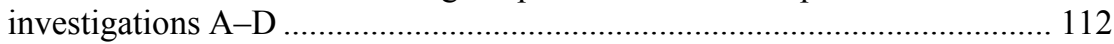

Annex C. Declaration of academic Integrity ........................................................ 114

Annex D. The co-authors' agreements to present publications for the

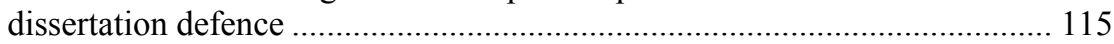

Annex E. Copies of scientific publications by the author on the topic

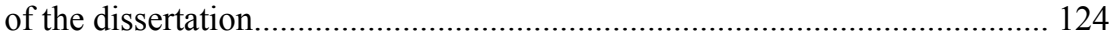

${ }^{2}$ The annexes are supplied in the enclosed compact disc. 



\section{Ivadas}

\section{Problemos formulavimas}

Pastaruoju metu daug dèmesio skiriama sudètingos formos, pažangių ir inovatyvių produktų gamybai. Daugeliu atvejų, siekiant pagerinti detalių, mazgų ar įrenginių eksploatacines charakteristikas, detalių viduje būtina suformuoti sudétingas aušinimo, tepimo ar oro kanalų erdvines sistemas, nepažeidžiant ir nepakeičiant išorinès gaminio formos. Šiam tikslui pasiekti naudojama selektyviojo lazerinio sukepinimo (angl. Selective Laser Sintering arba SLS) technologija.

SLS technologijos dèka užtikrinamas aukštas detalių formos tikslumas $( \pm 30 \mu \mathrm{m})$ ir gamybos atkartojamumas (reprodukcija), tačiau šiuo metu platesnis metalo selektyviojo lazerinio sukepinimo taikymas yra apribotas dèl šiai technologijai būdingų trūkumų (mažas atsparumas korozijai, didelis paviršiaus šiurkštumas, nevienodas sukepinto metalo kietumas ir kita). Metalo miltelių sukepinimas lazeriu yra daugkartinis procesas, kurio metu susidaro savita struktūra, kurios pagrindinis ypatumas yra susisiekiančių skirtingo dydžio porų sistema. Formuojant kiekvieną sluoksnị vyksta medžiagos užgrūdinimas esant dideliam temperatūros gradientui, dèl to sukepintame metale susidaro ženklūs liekamieji tempimo ịtempiai. Tai lemia, kad SLS būdu sukepinto metalo mechaninès ir tribologinès savybès neprilygsta tradiciniu liejimu suformuotiems plieno gami- 
niams. Dèl nepalankių eksploatacijos sąlygų (dideli temperatūriniai svyravimai, dilimo poveikis, drègmè ir kt.) sukepintų gaminių eksploatacijos laikas tesiekia 2-3 metus.

Šiuo metu gamyboje yra didelis poreikis naujų, inovatyvių apdorojimo būdų, skirtų sukepintų gaminių paviršiams apdoroti ir modifikuoti. Lazerinių technologijų panaudojimo galimybès ir suteikiami privalumai pagerintų detalių, mazgų bei gaminių eksploatavimo savybes ir sumažintų eksploatacines išlaidas.

Siūlomi tradiciniai sukepintų geležies pagrindo paviršių apdorojimo ir modifikavimo būdai yra labai brangūs ir reikalauja didelių laiko sąnaudų. Apdirbant šio tipo paviršius tradiciniais būdais, paveikiama tik detalès geometrija be galimybès modifikuoti apdorojamą paviršių.

\section{Darbo aktualumas}

Pastaruoju metu griežtinami reikalavimai pramonejje naudojamų ịrenginių, automobilių, žemės ūkio technikos ir kt. sukeliamai taršai. Siekiant atitikti šiuos reikalavimus būtina optimizuoti gamybos procesus, sumažinti remonto darbų laiko sąnaudas. Todèl šiuo metu yra labai didelis sparčių, ekonomiškai efektyvių gamybos ir paviršinio metalo sluoksnio apdorojimo ir modifikavimo technologijų poreikis.

Šio darbo idèja - ištirti sukepintų SLS būdu gaminių paskesnio lazerinio mikroapdorojimo galimybę ir nustatyti paviršinio sluoksnio lazerinio modifikavimo poveiki sluoksnio formavimosi procesui ir jo fizikinèms savybèms. Remiantis literatūros analize galima teigti, kad galutinis paviršiaus modifikavimas lazeriu leistų išvengti trūkumų, kurie būdingi tradicinei SLS technologijai (paviršiaus nelygumas ir didelès užlaidos mechaniniam apdorojimui iki $1 \mathrm{~mm}$ ), bei pagerinti metalinio sukepinto gaminio eksploatacines savybes. Galimybė lazerio spindulio pluoštą sukoncentruoti ị mažo skersmens dèmę leidžia gauti plonus modifikuoto metalo sluoksnius, kurių storis siekia $0,01-0,3 \mathrm{~mm}$. Trumpa proceso trukmė ir tiksliai dozuotas energijos įvedimas užtikrina minimalią terminio poveikio sriti ir minimalias deformacijas.

Sukepintų gaminių paviršiaus lazerinio modifikavimo proceso tyrimas suteiks naujų žinių apie geležies-nikelio-kobalto metalo paviršinio sluoksnio formavimosi procesą. Gautos žinios suteiks galimybę nustatyti lazerinio modifikavimo ir jo technologinių parametrų itaką sukepintam gaminiui. Tai leis pagerinti tokių gaminių atsparumą dilimui ir korozijai, sumažinti jų paviršiaus šiurkštumą, sumažinti gaminio kainą ir padidinti resursą. 


\section{Tyrimo objektas}

Selektyviuoju lazeriniu sukepinimo būdu pagaminti bei lazeriu papildomai apdoroti geležies-nikelio-kobalto pagrindo paviršiai.

\section{Darbo tikslas}

Nustatyti gaminių, sukepintų SLS būdu, paviršinio sluoksnio lazerinio mikroapdorojimo proceso ittaką sluoksnio formavimosi procesui ir jo mechaninèms, tribologinèms bei eksploatacinèms savybèms.

\section{Darbo uždaviniai}

Darbo tikslui pasiekti sprendžiami šie uždaviniai:

1. Ištirti lazerinio mikroapdorojimo technologinių parametrų (lazerio spindulio pluošto galios, apdirbimo greičio, ejimų skaičiaus) poveiki sukepintų SLS sluoksnių morfologijai, topografijai, mechaninėms, tribologinèms ir eksploatacinèms savybėms.

2. Nustatyti optimalius lazerinio mikroapdorojimo technologinius parametrus, siekiant gauti geresnių eksploatacinių savybių (lyginant su vien tik sukepintu sluoksniu) daugiafunkcị Fe-Ni-Co pagrindo paviršių.

\section{Tyrimų metodika}

Disertacijoje taikomi analitiniai ir eksperimentiniai tyrimo metodai.

Darbe tirta lazerinio mikroapdorojimo proceso ịtaka gaminių, sukepintų SLS būdu, paviršinio sluoksnio formavimosi procesui ir jo mechaninėms, tribologinèms bei eksploatacinèms savybėms. Bandymams buvo naudoti Fe-Ni-Co milteliu pagrindu sukepinti bandiniai, papildomai apdoroti koncentruotosios energijos šaltiniu. Fe-Ni-Co milteliu savybès tirtos naudojant skenuojamają elektroninę mikroskopiją, rentgeno mikroanalizę bei rentgeno spindulių difrakciją. Vien tik sukepintų ir papildomai lazerio spinduliuote apdorotų bandinių mikrostruktūra ir fazės tirtos taikant šiuolaikinius medžiagų tyrimo metodus: skenuojamają elektroninę mikroskopiją, rentgeno mikroanalizę, rentgeno spindulių difrakciją. Mechaninès, tribologinès ir eksploatacinès sukepintų ir sukepintų bei 
papildomai lazeriu apdorotų bandinių paviršių savybės tirtos atliekant kietumo, dilimo, atsparumo korozijai ir profilometrijos bandymus.

\section{Darbo mokslinis naujumas}

SLS technologija yra labai perspektyvi energetikos įrenginių, automobilių, lèktuvų, kosmoso, spaudos, medicinos ir kitose srityse. Gaminant sudètingos formos konstrukcines detales, gamyboje plačiai naudojamas selektyvusis lazerinis sukepinimas.

Eksperimentinių tyrimų metu nustatyti optimalūs sukepintų Fe-Ni-Co milteliu pagrindu gaminių papildomo mikrolazerinio apdorojimo parametrai. Tyrimais patvirtinta, kad SLS sukepintų gaminių papildomas lazerinis mikroapdorojimas užtikrina naujo, tankesnio sukepinto paviršinio metalo sluoksnio formavimosi procesą, geresnę topografiją, didesnị kietumą ir geresnị atsparumą dilimui. Rengiant disertaciją, gauti šie medžiagų inžinerijos mokslui nauji rezultatai:

1. Fe-Ni-Co miltelių pagrindu sukepintų SLS būdu gaminių papildomo lazerinio mikroapdorojimo technologija leidžia sukurti daugiafunkcị sluoksnị sukepinto bandinio paviršiuje, kuris pasižymi geresnėmis mechaninėmis, tribologinėmis ir eksploatacinėmis savybėmis.

2. Nustatytos SLS būdu sukepinto ir nanosekundinès veikos lazeriu apdoroto paviršinio sluoksnio morfologijos, topografijos, fazinès sudèties, mechaninių, tribologinių ir antikorozinių savybių sąsajos su lazeriniu apdorojimu ir jo parametrais, leidžiančios parinkti optimalius apdorojimo režimo parametrus konkrečioms eksploatacinèms sąlygoms.

\section{Darbo rezultatų praktinè reikšmė}

Fe-Ni-Co miltelių pagrindu SLS būdu sukepintų gaminių papildomo lazerinio mikroapdorojimo technologija gali būti pritaikyta pramonès srityse, kuriose plačiai naudojami labai svarbūs, sudètingos geometrijos gaminiai (polimerų liejimo formos, variklių ir turbinų detalès ir kt.). 


\section{Ginamasis teiginys}

SLS sukepintų Fe-Ni-Co miltelių pagrindo gaminių papildomo lazerinio mikroapdorojimo aukštas apdorojimo tikslumas, tikslus energijos įvedimas, trumpas apdoroto sluoksnio formavimo laikas lemia naujo sukepinto paviršinio metalo modifikuoto sluoksnio formavimą ir užtikrina geresnę paviršiaus topografiją, didesnị kietumą ir atsparumą dilimui.

\section{Darbo rezultatų aprobavimas}

Disertacijos tema yra išspausdinti 8 moksliniai straipsniai: 4 - tarptautinèse duomenų bazèse esančiuose recenzuojamuose mokslo žurnaluose, 4 - kituose recenzuojamuose mokslo leidiniuose.

Disertacijoje atliktų tyrimų rezultatai paskelbti dešimtyje mokslinių konferencijų Lietuvoje ir užsienyje:

- Jaunujų mokslininkų konferencijoje „Lietuva be mokslo - Lietuva be ateities" 2011 ir $2014 \mathrm{~m}$. Vilniuje.

- Tarptautinejje konferencijoje „Mechatronic Systems and Materials“ 2013 m. Vilniuje ir 2015 m. Kaune.

- Tarptautineje konferencijoje „Advanced Materials and Technologies“ 2013 m. Palangoje.

- Tarptautineje konferencijoje „The prospects of using functional coatings" 2015 m. Karagandoje.

- Tarptautineje konferencijoje „New materials and technologies: Powder metallurgy, Composite materials, Protective coatings, Welding“ 2016 m. Minske.

- Tarptautineje konferencijoje „Modern methods and technologies for the creation and processing of materials" 2015 ir 2016 m. Minske;

- Tarptautineje konferencijoje „Science integration, education and production - basis of the implementation of the Plan of the nation: Saginov's readings № 9“" 2017 m. Karagandoje.

\section{Disertacijos struktūra}

Disertaciją sudaro įvadas, trys skyriai ir bendrosios išvados. Taip pat yra 5 priedai. 
Darbo apimtis yra 106 puslapiai, neskaitant priedų, tekste panaudotos 6 numeruotos formulès, 53 paveikslai ir 13 lentelių. Rašant disertaciją, panaudoti 109 literatūros šaltiniai. 


\section{1}

\section{Adityviosios gamybos ir metalinių paviršių modifikavimo ypatumų analizė}

Skyriuje pateikiama kompleksinè adityviosios gamybos ir dalinè tradicinių plieno apdorojimo būdų analizè. Nagrinėjami metalinių paviršių fizikiniai lazerinio mikroapdorojimo technologijos ypatumai.

Skyriaus tematika paskelbti trys autoriaus (su bendraautoriais) straipsniai (Markovič et al. 2013a; Markovič et al. 2013b; Vaitkūnaitè et al. 2014).

\subsection{Adityvioji gamyba}

\subsubsection{Adityviosios gamybos plètra}

Adityvioji gamyba - tai technologija, kurią taikant galima gaminti erdvinius tūrius su įvairialype vidine struktūra ir plačiu kokybinių charakteristikų spektru. (Olakanmi et al. 2015). Pagrindinis AG principas yra gaminio erdvinio modelio (sukurto su CAD sistema) gamyba be jokios išankstinès apdorojimo technologijų sekos kūrimo. Esminis AG privalumas yra tai, kad detalè, gaminys, tūris ir kt. kuriami naudojant tik gaminio CAD modeli (Mishra et al. 2015). Tradicinès 
gamybos atveju tai yra neįmanoma, nes būtina išanalizuoti daugybę technologinių žingsnių bei jų seką, gamybos ịrenginių tinkamumą vienai ar kitai operacijai, žaliavų parinkimą, įrankių nomenklatūrą bei apdorojimą atliekančio personalo kvalifikacijos lygị (Kumar et al. 2007). AG šiuo požiūriu reikalauja tik gaminio matmenų, paviršinio technologijos proceso supratimo bei žaliavos. Tokiu būdu gerokai sumažinami apdorojimo kaštai, operacijų, reikalingų detalei apdirbti, skaičius, gamybos laikas (Paulic et al. 2014).

Daugelis mokslininkų AG apibrèžia kaip revoliuciją apdorojimo pramonëje. Kai kurie netgi teigia, kad tokio tradicinio apdorojimo, kokị mes žinome, ateityje nebeliks (Bauereiss et al. 2014).

Daugeliu atvejų, siekiant pagerinti detalių, mazgų ar ịrenginių eksploatacines charakteristikas, jų viduje būtina suformuoti sudėtingas aušinimo, tepimo ar oro kanalų sistemas taip, kad nebūtų pažeista ir pakeista išorinè gaminio forma (Manzirov et al. 2017).

AG technologijos pagrindą sudaro erdvinio tūrio priauginimas sluoksnis po sluoksnio (Chavoshi et al. 2016). Kiekvienas sluoksnis yra skersinis detalès pjūvis, sukurtas naudojant $C A D$ modelį. Visi $A G$ ịrenginiai naudoja tą patị veikimo principą. Jie skiriasi tik naudojamomis medžiagomis, pavienių tūrio sluoksnių paskirstymu darbo zonoje bei miltelių tarpusavio sujungimo būdu (Balachninaitè et al. 2008). AG technologija gali būti taikoma ne tik prototipų, bet ir sudètingų bei atsakingų gaminiu gamyboje. AG technologija yra daugialypé sistema, kurioje technologinių veiksmų seka priklauso nuo gaminamos detalès sudètingumo bei kompleksiškumo. Kai AG yra naudojama kartu su kitomis technologijomis, formuojant gamybinių procesų seką, užtikrinamas trumpesnis gaminio gamybos laikas bei mažesni kaštai (Chavoshi et al. 2016). Šia hibridine technologija gaunamas visavertis galutinis produktas, kuriam netaikomi geometriniai apribojimai (Huang et al. 2016).

AG sudaro šie etapai (Gibson et al. 2013):

- Erdvinio modelio projektavimas. Visų AG detalių gamyba prasideda nuo erdvinio modelio projektavimo, kuris atspindi gaminio geometriją. Šis procesas gali būti atliktas su dauguma šiuolaikiniam pasauliui žinomų grafinių programų (Olakanmi et al. 2015).

- Erdvinio modelio konvertavimas ị STL formatą. AG ịrenginiai dirba tik STL duomenų formatu. Beveik visa žinoma CAD programinè įranga palaiko šị formatą. Tokiu būdu paruošti duomenys leidžia sudaryti gaminio gamybos procesą.

- Erdvinio modelio perkèlimas i AG ịrenginị. Skaitinis STL modelis privalo būti perkeltas ì AG ịrenginị. Čia atliekama bendra erdvinio modelio patikra: gabaritinių matmenų, geometrijos ir kt. (Paul et al. 2012). 
- Technologinių procesų parametrų nustatymas. Siekiant užtikrinti gamybos proceso našumą, prieš darbo pradžią atliekamas šių technologinių parametrų optimizavimas: lazerio spindulio pluošto galios, sukepinamo sluoksnio storio, lazerio poveikio laiko, apdorojimo greičio ir kt. (Farahmand et al. 2014).

- Gamyba. Automatizuotas procesas, nereikalaujantis nuolatinès profesionalios priežiūros. Tačiau minimalus monitoringas, siekiant įsitikinti, kad irenginys veikia tinkamai, yra rekomenduojamas. Šiuo atveju stebimi tik šie technologiniai sutrikimai: elektros dingimas, žaliavos stygius, mechaninis gedimas.

- Papildomas apdorojimas. AG būdu pagamintos detalès neretai turi būti papildomai apdorotos rankiniu arba mašininiu būdu, siekiant užtikrinti gaminio atitiktị aukštiems kokybès reikalavimams (Zhu et al. 2016). AG pagamintų tūrių metalas nepasižymi kietumu, tačiau savaime aišku, kad papildomas terminis apdorojimas yra būtinas, jei to reikalauja gaminio techninès charakteristikos. Liauno, nestandaus arba mažagabaričio gaminio atveju stabiliam AG procesui užtikrinti būtinos papildomos technologinès bazès, kurias privalu pašalinti procesui pasibaigus. Būtina pabrëžti, kad papildomas apdorojimas reikalauja kvalifikuoto ir labai patyrusio personalo, kadangi AG gaminių apdorojimas ne tik imlus laiko atžvilgiu, bet ir labai specifinis procesas, reikalaujantis kruopštumo, susikaupimo ir neeilinių gebejjimų. Papildomi technologiniai veiksmai, naudojami AG produktams apdirbti, yra šios disertacijos tyrimų tikslas.

- Gaminio pritaikymas. Atskirais atvejais reikalaujamas papildomas išorinių paviršių dekoravimas, pvz.: gruntavimas, dažymas. Dažnai AG produktus būtina surinkti ị mazgus ar mechanizmus, norint ịvertinti jų funkcionalumą ir estetinį vaizdą. (Manzirov et al. 2017). Būtina pabrèžti, kad žaliavai keliami aukšti kokybės reikalavimai. Daugeliu atvejų tai ịvairios formos ir sudèties milteliai. Jų sandèliavimo, saugojimo sąlygos yra griežtai apibrěžtos, siekiant eliminuoti jų chemines reakcijas su išoriniais veiksniais. AG neretai naudojamos antrinès žaliavos. Šio tipo žaliavoms labai svarbu užtikrinti pradinę kontrolę, nes pakartotinis perdirbimas gali lemti žaliavos kokybės rodiklių pablogèjimą ir tuo pačiu turèti įtakos gaminio kokybei.

\subsubsection{Selektyvusis lazerinis sukepinimas}

Selektyvusis lazerinis sukepinimas - tai AG technologijų grupei priklausantis procesas (1.1 pav.). Kurio dèka galima itin sudètingos geometrinès formos ir kompleksinių technologinių sprendimų detalių, mazgų ir ịrenginių gamyba (Chavoshi et al. 2016). Literatūroje SLS apibūdinamas kaip tam tikros geomet- 
rinès formos tūrio gamyba žingsnis po žingsnio arba sluoksnis po sluoksnio (Chavoshi et al. 2016; Manzirov et al. 2017; Merklein et al. 2016; Newman et al. 2015; Shukla et al. 2016; Hu et al. 2011).

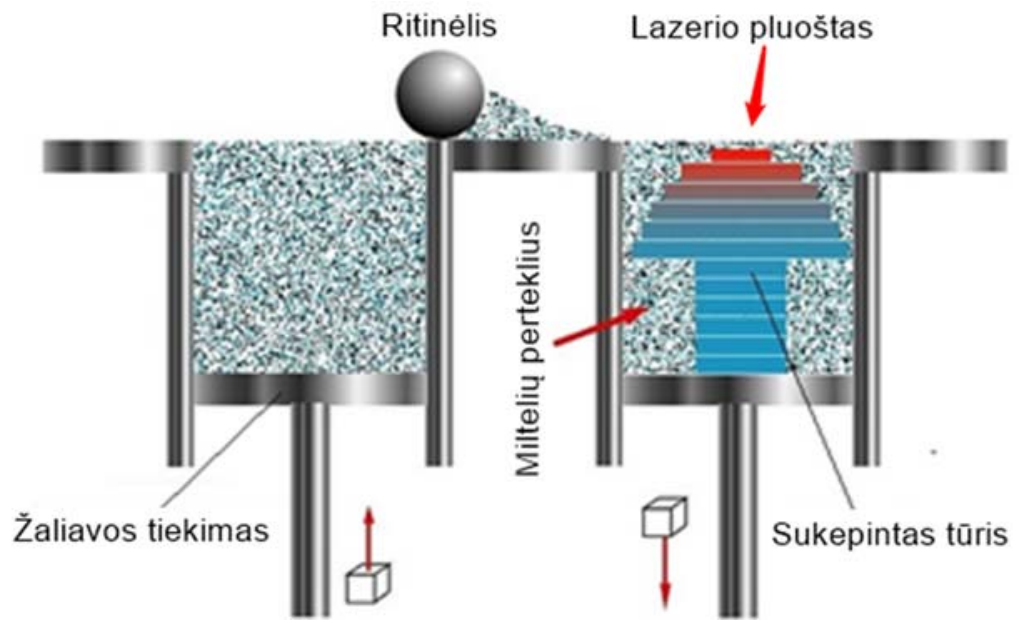

1.1 pav. Selektyviojo lazerinio sukepinimo procesas (Kemplon engineering)

Fig. 1.1. The process of the selective laser sintering

Pastaruoju metu medžiagų sintezė bei jų apdorojimo metodai tampa aktualiu klausimu medžiagų raidos srityje, todèl sukepinimo technologija ir jos tobulinimas yra pagrindinis uždavinys sprendžiant ši klausimą. Nepaisant to, kad sukepinimo procesas žinomas nuo Kristaus laikų, tačiau išsamus šio reiškinio tyrimas pradètas tik 1940 metais (Olakanmi et al. 2015). Pagrindinis šios technologijos privalumas yra tai, kad sukepinimo būdu tarpusavyje galima sujungti praktiškai visų rūšių medžiagas. Prieš pradedant gamybą, kaip ir kiekvieno inžinerinio proceso metu, būtina visapusiškai išnagrinèti būsimam gaminiui keliamus reikalavimus.

Pagrindinis sukepinimo tikslas - pagaminti tam tikros geometrijos tūrị su pageidaujamomis morfologinèmis ir topografinèmis charakteristikomis, keičiant proceso technologinius parametrus bei turint galimybę atkartoti arba pagaminti naują, tokị patị tūị (Paul et al. 2012).

Bendru atveju sukepinimas skirstomas ị kietos ir skystos fazès sukepinimą.

Kietos fazès sukepinimas vyksta tada, kai miltelinio pagrindo medžiaga sukepinama nesant skystos fazès (Manzirov 2017). Tai yra neviršijant miltelių medžiagos lydymosi temperatūros. Skystos fazès sukepinimo atveju proceso temperatūra yra didesnè nei sukepinamos medžiagos lydymosi temperatūra (Ba- 
lachninaitè et al. 2008). Esant skystos fazès sukepinimo atvejui, gaunamas kokybiškesnis gaminys negu esant kietos fazès sukepinimui (Merklein et al. 2016).

Sukepinimo proceso kokybei įtakos turintys kintamieji parametrai skirstomi i dvi pagrindines kategorijas:

- žaliavos;

- technologiniai proceso parametrai.

Kintamieji parametrai, turintys įtakos sukepinimo procesui, priskiriami žaliavų kategorijai:

- miltelių cheminè sudètis;

- miltelių frakcijos dydis;

- milteliu geometrinè forma;

- miltelių sulipimo ir išsimaišymo laipsnis.

Šie kintamieji parametrai veikia miltelių sukepinimą, spūdumą, grūdelių augimo greitị ir jų plastines savybes (Merklein et al. 2016).

Sukepinimas neįmanomas be aukštos kokybės žaliavos. Yra keli medžiagu mechaninio smulkinimo būdai, tačiau labiausiai paplitę šie malūnai: rutuliniai, planetariniai, išcentriniai, vibraciniai, atritoriniai ir kt. (Valiulis 2005).

Tokiu atveju, jei žaliava sudaryta iš dviejų ir daugiau rūšių miltelių, sukepinamos žaliavos homogeniškumas arba, kitaip sakant, išsimaišymo laipsnis turi didelę įtaką. Siekiant užtikrinti žaliavos homogeniškumą naudojamas ne tik mechaninis miltelių malimas, bet ir cheminiai procesai (Farahmand et al. 2016).

Kintamiejji parametrai, priskiriami technologinių procesų kategorijai, apima šias sritis:

- proceso temperatūrą;

- atmosferos slègi;

- kaitinimo ir aušinimo greiț.

\subsection{Tradicinių metalinių paviršių apdorojimo būdų apžvalga}

Siekiant nustatyti pagrindinius skirtumus tarp tradicinių ir inovatyvių metalinių paviršių apdorojimo būdų, būtina nuodugniai išanalizuoti tradicinių metalinių paviršių apdorojimo būdų ypatumus. Atsižvelgiant ị tai, kad lazerinio apdorojimo metu galimas ne tik geometrinių, bet ir mechaninių, fizikinių ir cheminių apdirbamojo paviršiaus charakteristikų pokytis, būtina suprasti, kokiu būdu pasiekiamas analogiškas rezultatas taikant tradicinius apdorojimo būdus. Toliau pateikiama populiariausių metalinių paviršių apdorojimo būdų apžvalga.

Taikant ịvairius pjovimo metodus, nuo ruošinio nuimamas tam tikro storio medžiagos sluoksnis (1.2 pav.), tuo pačiu gaunama reikiamos formos ir matmenų detalè (Binder et al. 2017). Pjovimo ịrankis - tai metalo pjovimo staklių da- 
lis, tiesiogiai pjaunanti ruošinį, iš kurio turi būti pagaminta detalè (Cui et al. 2017). Pjaunamas metalas gniuždomas, tempiamas, vyksta šlytis, susidaro didelè trintis, išsiskiria daug šilumos (Rodriguez et al. 2017).

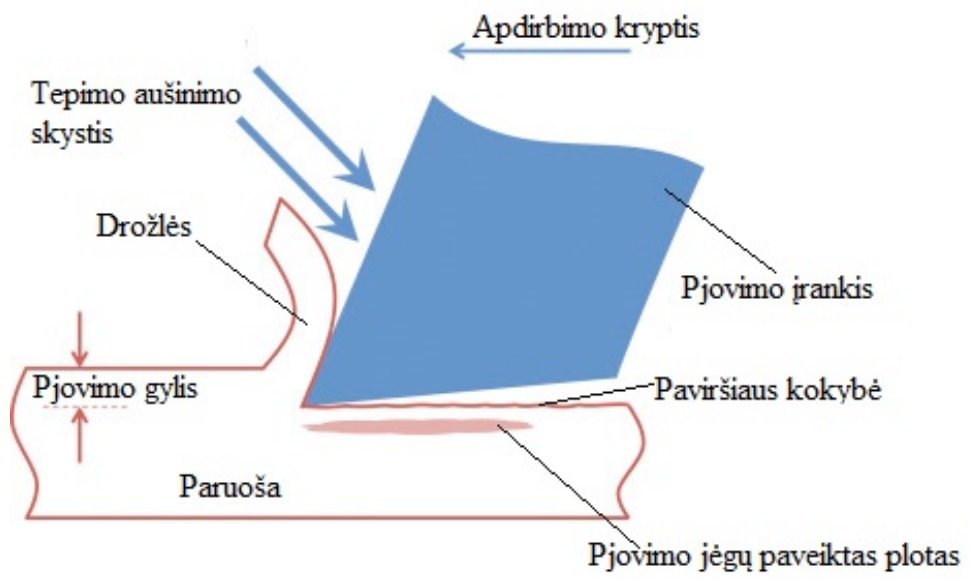

1.2 pav. Metalo apdorojimas pjovimu (Slide player)

Fig. 1.2. Steel processing by cutting

Frezavimas - tai labai našus ir plačiai taikomas metalo ir kitokių konstrukcinių medžiagų apdorojimo daugiaašmeniais pjovimo ịrankiais būdas. Ivvairių tipų frezomis formuojami detalių plokšti, laiptuoti paviršiai, grioveliai, kontūriniai, reljefiniai ir fasoniniai paviršiai. Tačiau frezavimo proceso trūkumas yra tas, kad frezos dantys pjauna kintamo skerspjūvio drožles, įrankio briauna iš pradžiu slysta pjovimo paviršiumi ji sukietindama ir šiurkštindama. Todèl frezuojant poveikio jègos yra pulsuojančios, atsiranda sunkiai panaikinamų vibracijų, kurios didina apdirbamojo paviršiaus šiurkštumą ir sunkina pjovimą (Binder et al. 2017).

Gręžimas - tai vienas labiausiai paplitusių ir seniausių metalo pjovimo būdų kiauroms ir aklinoms skylèms formuoti (Abouridouane et al. 2017). Pjovimo ịrankiai yra grąžtai. Jais gręžiamos skylès ištisiniame metale arba pakartotinai gręžiamos didinant anksčiau išgręžtų skylių skersmenis (Smolenicki et al. 2012).

Gręžiant spiraliniais grąžtais, kurių skersmuo didesnis kaip $15 \mathrm{~mm}$, gaunamos 11-12 kvaliteto tikslumo skylès, o apdirbto paviršiaus šiurkštumas iki $R_{z}=$ 10-20 $\mu \mathrm{m}$. Gręžiant mažesnio kaip $15 \mu \mathrm{mm}$ skersmens grąžtais, yra pasiekiamas iki 8 kvaliteto skylès tikslumas ir iki $R_{a}=1,25-2,5 \mu$ m paviršiaus šiurkštumas (Parsian et al. 2017).

Šlifavimo abrazyviniais diskais operacijos plačiai taikomos metalui ir kitoms konstrukcinèms medžiagoms apdirbti, kai reikia gauti didelio tikslumo (iki 
4-ojo kvaliteto) ir mažo paviršiaus šiurkštumo (iki $R_{a} 0,04 \mu \mathrm{m}$ ) detales (Ivanova 2016). Be to, šlifavimo būdu detalès gali būti rupiai apdirbamos, nuvalomi liejimo, kalimo, frezavimo, tekinimo bei suvirinimo siūlių nelygumai, pjaunamos labai kietos medžiagos (virš $60 \mathrm{HRC}$ ), galandami ịvairūs įrankiai (Silva et al. 2017).

Ślifavimas yra daug sudètingesnis už tekinimą, gręžimą, frezavimą ir kitus pjovimo būdus. Šlifavimo diskas yra daugiaašmenis pjovimo įrankis, sudarytas iš daugybės rišančiaja medžiaga sujungtų pjovimo elementų, kurie būna netaisyklingos daugiabriaunès formos su aštriomis arba suapvalintomis briaunelèmis (Silva et al. 2017). Sukantis diskui, abrazyviniai grūdeliai dideliu greičiu pjauna daugybę smulkių netaisyklingos formos drožlelių. Abrazyviniai grūdeliai pjauna metalą sunkiomis sąlygomis, nes daugumos jų pjovimo briaunelès yra suapvalintos, netaisyklingos formos, su neigiamais priekiniais kampais (Ding et al. 2016). Dèl netobulos ir atsitiktinès pjaunančiųu grūdelių formos negalima reguliuoti pjovimo proceso, o tuo pačiu prognozuoti apdorojimo kokybès.

Elektrokibirkštinio tūrinès erozijos apdorojimo pagrindą sudaro termoelektrinès energijos panaudojimas medžiagos tūriui išlydyti arba pašalinti. Valdant aukšto dažnio elektros iškrovą, apdirbami sudètingi fasoniniai, reljefiniai išoriniai ir vidiniai paviršiai.

Elektrokibirkštinio apdorojimo metu tarpelis tarp ị dielektrinị skystị panardintos detalès bei elektrodo siekia nuo 0,01 iki $0,5 \mathrm{~mm}$. Iškrovai suformuoti naudojama įtampa, priklausanti nuo tarpelio bei dielektrinio skysčio savybių. Medžiagos apdorojimas vyksta dèl elektros srovès tarp elektrodo ir detalès, dèl kurios vyksta metalo dalelių erozija.

Siekiant apibendrinti technologijos pasirinkimo kriterijus, būtina atlikti adityviosios gamybos ir tradicinio apdorojimo palyginimą (1.1 lentelè).

1.1 lentelè. Adityviosios gamybos ir tradicinio apdorojimo palyginimas

Table 1.1. The comparison between additive manufacturing and traditional processing

\begin{tabular}{|l|l|l|l|}
\hline \multicolumn{1}{|c|}{$\begin{array}{c}\text { Parametro } \\
\text { pavadinimas }\end{array}$} & \multicolumn{1}{|c|}{$\begin{array}{c}\text { Adityvioji } \\
\text { gamyba }\end{array}$} & $\begin{array}{c}\text { Tradicinis } \\
\text { apdorojimas }\end{array}$ & \multicolumn{1}{c|}{ Pastaba } \\
\hline Žaliavos tipas & Milteliai & Kietas kūnas & $\begin{array}{l}\text { Milteliams, kaip } \\
\text { žaliavai, keliami } \\
\text { aukšti kokybès } \\
\text { reikalavimai }\end{array}$ \\
\hline Apdorojimo sparta & $2 \mathrm{~cm}^{3} / 3600 \mathrm{~s}$ & iki $1 \mathrm{~cm}^{3} / 5 \mathrm{~s}$ & $\begin{array}{l}\text { Tradicinio apdoro- } \\
\text { jimo spartą lemia } \\
\text { daugelis veiksnių }\end{array}$ \\
\hline
\end{tabular}


1.1 lentelès pabaiga

\begin{tabular}{|l|l|l|l|}
\hline \multicolumn{1}{|c|}{$\begin{array}{c}\text { Parametro } \\
\text { pavadinimas }\end{array}$} & \multicolumn{1}{|c|}{$\begin{array}{c}\text { Adityvioji } \\
\text { gamyba }\end{array}$} & \multicolumn{1}{|c|}{$\begin{array}{c}\text { Tradicinis } \\
\text { apdorojimas }\end{array}$} & Pastaba \\
\hline $\begin{array}{l}\text { Technologinių } \\
\text { operacijų seka }\end{array}$ & Elementari & Sudètinga & $\begin{array}{l}\text { Tradicinis apdoroji- } \\
\text { mas reikalauja } \\
\text { daugiau techno- } \\
\text { loginių žinių }\end{array}$ \\
\hline Kompleksiškumas & Aukštas & Žemas & $\begin{array}{l}\text { Tradicinis apdoroji- } \\
\text { mas neleidžia modi- } \\
\text { fikuoti apdirbamo } \\
\text { paviršiaus }\end{array}$ \\
\hline Tikslumas & $\pm 0,05$ mm & $\pm 0,002 \mathrm{~mm}$ & $\begin{array}{l}\text { Žiūrèti } 1.3 \\
\text { paveiksle. }\end{array}$ \\
\hline $\begin{array}{l}\text { Geometriniai } \\
\text { apribojimai }\end{array}$ & Nèra & Daug & \\
\hline Programavimas & Elementarus & Sudètingas & \\
\hline
\end{tabular}

Lyginant AG ir tradicinių metalinių medžiagų apdorojimo būdus, galima teigti, kad didžiausias AG technologijos pranašumas atsiranda sudètingos geometrijos gaminiu gamybos metu. Tradicinio apdorojimo atveju našus apdorojimas galimas tik esant paprastai gaminio geometrijai: cilindras, plokštuma, kūgis, sfera ir kt. Kūno, pavaizduoto 1.3 paveiksle apdorojimas tradiciniu būdu įmanomas tik keičiant detalès padètị staklèse. Tai lemia geometrinių parametrų tikslumą ir gamybos laiką.

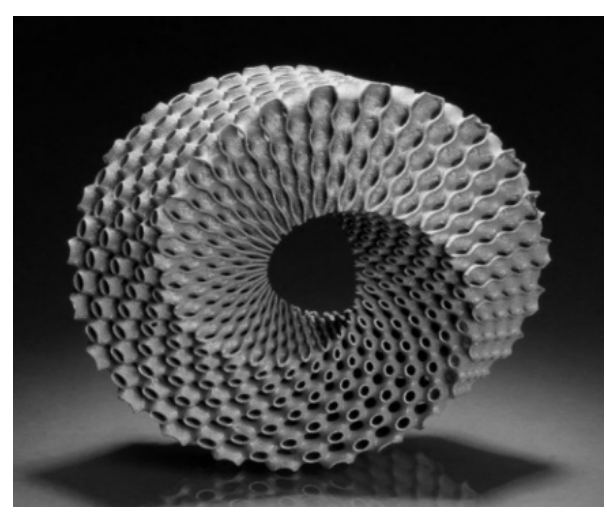

1.3 pav. Sudètingos geometrinès formos gaminys ( $3 \mathrm{~d}$ maastricht)

Fig. 1.3. The part with difficult shape 


\subsection{Inovatyviụjų metalinių paviršių apdorojimo būdų apžvalga}

\subsubsection{Apdorojimas lazerio spindulio pluoštu}

Šiandien lazeriai taikomi ne tik praktikoje, bet ir buityje. Jie naudojami ruošiniams pjauti ir suvirinti laivininkysteje, automobilių pramoneje, medicinoje, apšvietimo technikoje, metrologijoje, medžiagu inžinerijoje, elektronikoje, mikroinžinerijoje (Balachninaitè et al. 2008).

Lazerinio paviršių apdorojimo panaudojimas pramonèje didèja dèl šių lazerinès technologijos savybių (Mishra et al. 2015):

- Lokalus terminis poveikis. Lazerinio apdorojimo proceso našumas priklauso nuo šiluminių ir fizikinių apdorojamo kūno charakteristikų. Trapios ir kietos detalès gali būti sèkmingai apdorojamos lazeriniu būdu.

- Proceso lankstumas. Lazerinis apdorojimas pasižymi proceso lankstumu. Šiuo atveju vienu metu galima vykdyti skirtingus medžiagos apdorojimo būdus: pjovimą, suvirinimą, gręžimą, grūdinimą, atleidimą, normalizavimą, atkaitinimą ir kt.

- Neinvazinis apdorojimas. Vibracija, drožlès, abrazyvo dalelès - šie reiškiniai yra pašalinami lazerinio apdorojimo metu (Lombardo et al. 2017).

- Ekonominis efektyvumas. Lazerinis apdorojimas, lyginant su tradicine gamyba yra efektyvesnis, universalesnis, turintis didesni potencialą, mažiau imlus laiko sąnaudoms (Manzirov 2017).

Vertinant šiuos esminius bruožus, akivaizdu, kad šis inovatyvus procesas ekonominiu požiūriu nepalyginamai efektyvesnis.

\subsubsection{Medžiagų mikroapdorojimas lazeriu spindulio pluoštu}

Apdirbamo kūno paviršiaus kaitinimas atsiranda dèl lazerinès spinduliuotès sugerties. Keičiant lazerinès spinduliuotès energetinius parametrus, gaunami skirtingi lazerinio apdorojimo procesai (Balachninaite et al. 2008). Apdorojimas lazeriu dèl labai mažo terminio poveikio lauko bei aukšto tikslumo apibūdinamas kaip mikrolazerinis apdorojimas.

Vienas labiausiai paplitusių ir perspektyviausių lazerinio apdorojimo būdų yra sukietinimas. Šiuo būdu galima sukietinti detalių paviršius, ypač tada, kai reikalingas lokalus poveikis. Šiuo būdu taip pat galima keisti sukietinamo sluoksnio gylį, nekeičiant detalès geometrinių matmenų. Tai ypač svarbu tiksliųjų prietaisų ir mechanizmų gamyboje (Kumar et al. 2009).

Sukietinto medžiagos sluoksnio storis, plotis, kietumas ir kt. daugiausia priklauso nuo (Gu et al. 2009): 
- spinduliuotès energetinių parametrų;

- fizikinių medžiagos charakteristikų;

- apdirbamo kūno gabaritinių matmenų;

- apdorojimo greičio.

Sukietintas sluoksnis paprastai būna ne storesnis kaip $2 \mathrm{~mm}$. Naudojant šią technologiją, brangų legiruotaji plieną galima pakeisti angliniu. Šiluminio poveikio intensyvumas gali būti keičiamas plačiose ribose, reguliuojant ịkaitinimo, aušinimo greičius bei poveikio laiką. Tokiu būdu galima gauti reikiamą detalès struktūrą ir savybes (Ulkar et al. 2010). Technologinès lazerinio sukietinimo galimybès leidžia naudoti ši procesą kaip baigiamają operaciją be tolesnio mechaninio apdorojimo. Be to, tam tikras surinkto mechanizmo ar mazgo vietas galima sukietinti surinkus konstrukciją ar atskirą mazgą (Jiang et al. 2005).

Lazerinis paviršiu kietinimas paprastai atliekamas pagal tris schemas (1.4 pav.) (Balachninaitè et al. 2008):

1. Naudojami impulsinès veikos lazeriai. Paviršinio sluoksnio apdorojimas atliekamas pagal 1.4 paveiksle pateiktą impulsinio apdorojimo schemą.

2. Naudojami nuolatinès veikos lazeriai. Paviršinio sluoksnio apdorojimas atliekamas pagal 1.4 paveiksle pateiktą apdorojimo zigzagu schemą.

3. Naudojami nuolatinès veikos, didelès galios lazeriai. Paviršinio sluoksnio apdorojimas atliekamas pagal 1.4 paveiksle pateiktą tiesialinijinio apdorojimo schemą.

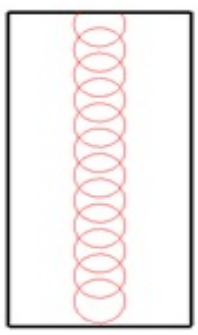

a)

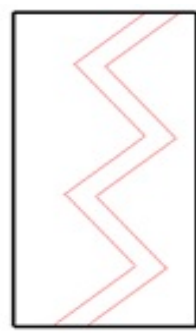

b)

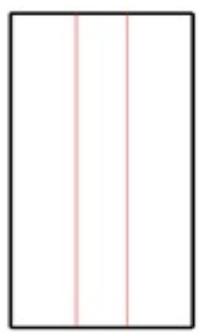

c)

1.4 pav. Lazerinio sukietinimo schema: a) impulsinio apdorojimo;

b) apdorojimo zigzagu; c) tiesialinijinio apdorojimo

Fig. 1.4. Scheme of laser treatment: a) impulse processing;

b) zigzag processing; c) rectilineal processing 
Lazerio spinduliuote sukietintas metalo sluoksnis susideda iš trijų būdingų mechaninio kietumo sričiu (Kumar et al. 2007):

- Pirmoji sritis - tai sukietintas paviršiaus sluoksnis, kuris maždaug 0,03$0,08 \mathrm{~mm}$ gylyje yra šiek tiek minkštesnis (atsileidęs) negu giliau esantis.

- Antroji sritis yra didžiausio metalo kietumo sritis. Didejant atstumui nuo gaminio paviršiaus, metalo kietumas laipsniškai mažèja ir pasiekia dydị, mažesnị už kritinị, t. y. mažesnị už pagrindinio metalo kietumą, kai grūdinama tūriniu būdu.

- Trečioji sritis - jos kietumas yra mažesnis dèl to, kad lètai sklindant šilumai ị gilesnius sluoksnius, užgrūdintas metalas atsileidžia.

Sukietinimas impulsinio technologinio lazerio spinduliuote yra palyginti lètas procesas ir daugiausia naudojamas smulkių detalių ir mažų matmenų ịrankių paviršiams apdirbti. Šio proceso našumas nedidelis, nes tokių technologinių lazerių impulsų pasikartojimo dažnis paprastai ne didesnis kaip $30 \mathrm{~Hz}$ (Jiang et al. 2005).

Gerokai efektyviau sukietinama nuolatinès veikos lazeriais. Jais gaunamas storesnis ir tolygesnis sukietintas sluoksnis, o procesas vyksta 2-4 kartus greičiau negu sukietinant impulsiniais lazeriais (Jiang et al. 2005).

Lazeriu sukietinto metalo paviršius dèl terminio poveikio iš dalies oksiduojasi ir yra tamsesnès spalvos negu paviršius, nepaveiktas lazerio spinduliuotès. Lazerio spinduliuote sukietintas sluoksnis yra ryškiai matomas detalès paviršiuje. Einant gilyn, metalo struktūra iš smulkiagrūdès pamažu pereina i pradinę struktūrą. Toks lazerio spinduliuote sukietintas sluoksnis, laipsniškai pereinantis i pradinę struktūrą, yra gerai sukibęs ir eksploatuojant labai patvarus (Murthy et al. 2011).

Smūginis kietinimas. Šiuolaikiniai lazeriai leidžia gauti labai didelio intensyvumo $10^{10}-10^{12} \mathrm{~W} / \mathrm{cm}^{2}$ ir mažos trukmès $10^{-8}-10^{-14} \mathrm{~s}$ impulsus. Impulso trukmè priarteja prie relaksacijos laiko $10^{-9}-10^{-11} \mathrm{~s}$. Dèl to lazerio spinduliuotès šiluminè energija nespeja giliau ịsiskverbti i pagrindini metalą. Labai didelè energijos koncentracija paviršinio sluoksnio mikrotūryje sukelia medžiagos plazminę būseną (Sovizi et al. 2005). Susidarant plazmai, kyla didelis slègis ir gali susiformuoti, kaip ir sprogimo atveju, smūginè banga. Iš esmès lazerio poveikis apdirbamam paviršiui yra labiau mechaninis nei terminis. Smūginė banga susiformuoja tik tada, jeigu lazerio spinduliuotés poveikio trukmė trumpesnè už smūginès bangos sklidimo laiką (Zhang et al. 2007).

Apdirbamą paviršių veikiantis mechaninio poveikio impulsas kyla medžiagai staigiai pereinant ị plazminę būseną ir išgaruojant ị aplinką. Taigi, išgaruojant medžiagai, paviršiaus plotą veikia mechaninis impulsas (Zhang et al. 2007).

Vienu metu veikiant ir smūgio bangai, ir mechaniniam impulsui, paviršiuje susidaro kūgio formos įduba. 
Pagrindinis paviršių smūginio kietinimo trūkumas - paviršiuje susidaro įdubų, kurios pablogina apdirbamo paviršiaus kokybę.

Grūdinimas. Vienas iš esminių paviršių apdorojimo lazerio spindulio pluoštu pranašumų - labai staigus, lokalus paviršiaus ịkaitinimas su paskesniu greitu aušinimu. Šis metodas labai efektyviai taikomas paviršiams grūdinti (Romano et al. 2015). Kadangi grūdinamos detalès paviršius greitai ịkaista ir greitai ataušta, jame susidaro smulkiagrūdžio martensito sluoksnis. Dèl susidariusių didelių terminių ịtempių, plastiškai deformuojasi metalo kristalinè gardelè ir padidejja dislokacijų tankis. Dèl to paviršinis sluoksnis užsigrūdina ir tampa gerokai atsparesnis mechaniniam dilimui (Kumar et al. 2007). Metalo grūdinto sluoksnio kietumas ir storis yra susiję. Kuo daugiau metalas sugeria lazerio spinduliuotès, tuo gilesnis poveikis ir tuo kietesnis būna paviršinis sluoksnis (Romano et al. 2015). Didinant spinduliuotès intensyvumą, detalès paviršius gali pradèti lydytis.

Lazerio spinduliuote užgrūdintas paviršinis sluoksnis susideda iš keturių sričių (Gillner et al. 2005):

- Pagrindinio metalo srities.

- Atleidimo srities, kurios kietumas gerokai sumažèjęs, nes nebėra martensito.

- Terminio poveikio srities. Tai didžiausio kiečio martensitinès struktūros sritis, kartais gali susidaryti baltas sluoksnis. Apatinèje šios srities dalyje yra martensitinès ir feritinès struktūros grūdinimo zona.

- Išlydytos srities, kurios struktūra paprastai būna dendritiniai martensito kristalai. Tai užgrūdintas paviršinis sluoksnis, kuris maždaug $0,02-$ $0,08 \mathrm{~mm}$ gylyje gali būti šiek tiek minkštesnis negu gilesnèje srityje.

Paviršių aplydymas. Lazerinis paviršiaus aplydymas atliekamas panašiu būdu kaip ir grūdinant, tik papildomai išlydomas paviršinis detalès sluoksnis. Lazerinio aplydymo metu apdirbamos detalès paviršiniame sluoksnyje vyksta sudètingi procesai: skysto metalo zonoje stebimi aukšti temperatūros gradientai, o tai sukelia didelius paviršiaus įtempius bei skysto metalo konvekciją (Kumar et al. 2007). Paviršinio sluoksnio mikroreljefui didžiausią įtaką turi lazerinès spinduliuotès intensyvumas (Gu et al. 2009).

Paviršiu legiravimas. Legiravimas lazeriu nuo lazerinio grūdinimo skiriasi tuo, kad keičiasi sukietinto paviršinio sluoksnio cheminè sudètis.

Legiravimas lazeriu yra nesudètingas ir spartus procesas. Detalès paviršius padengiamas legiruojamu elementu, miltelių sluoksniu arba ịvairių rūšių pastomis. Lazerio veikiamas paviršius susilydo su legiruojamu sluoksniu, todèl legiravimo elementai difunduoja ị pagrindinị metalą.

Ruošinys su plonu legiruojamu elementų sluoksniu juda tam tikru greičiu. Veikiamas lazerio spinduliuotès, paviršius lydosi ir legiravimo elementai patenka ị skysto metalo vonią, kur vèliau kristalizuojasi. Legiravimo metu vyksta sudetingi masès ir šilumos mainai bei mikrometalurginiai procesai (Gillner et al. 
2005). Susidaro naujo lydinio sluoksnis, tvirtai sujungtas su pagrindinio metalo tūriu. Šio sluoksnio mikrostruktūra ir gylis iš esmès priklauso nuo spinduliuotès intensyvumo, poveikio trukmès ir svyruoja nuo 0,05 iki $2 \mathrm{~mm}$ (Murthy et al. 2011).

Tam, kad lazeriu legiruotas paviršius būtų lygus ir glotnus, reikia atlikti baigiamają apdorojimo operaciją, pavyzdžiui, paviršių nušlifuoti. Lazerinio legiravimo metu reikia parinkti tikslius energetinius parametrus ir režimus, juos optimizuoti kiekvienam legiravimo elementui arba kelių legiravimo elementų mišiniui ir pagrindiniam metalui (Balachninaitè et al. 2008). Nuo legiruojančiujų elementų kiekio priklauso konstrukcinès medžiagos, gaminio, mazgo eksploatacinès ir kokybinès charakteristikos. 1-ame priede pateikiami dažniausiai naudojami elementai, skirti plienui legiruoti.

Gausiai legiruoti metalų lydiniai dažniausiai naudojami chemijos ir naftos pramoneje, energetikoje, medicinoje, aviacijoje, laivams statyti, mašinoms ir irankiams gaminti, raketų ir atominei technikai.

Paviršiu amorfinimas. Kai išlydytas paviršinis sluoksnis staigiai ataušinamas $10^{5}-10^{8} \mathrm{~K} / \mathrm{s}$, kai kurių metalų klampumas tiek daug padidèja, kad nespejja susiformuoti metalo kristalizacijos centrai ir metalo paviršinis sluoksnis kietèdamas ịgauna amorfinę struktūrą (Zhang et al. 2007). Amorfintam metalo paviršiniam sluoksniui būdingas netvarkingas atomų išdèstymas, jis pasižymi izotropiškumu. Medžiagos tinkamumas amorfizacijai priklauso nuo cheminės sudèties, aušinimo greičio, kristalizacijos centrų susiformavimo greičio ir kitų veiksnių (Gillner et al. 2005). Naudojant paviršių amorfinimo technologiją, gaunami feromagnetiniai lydiniai, turintys ypatingų magnetinių savybių. Jų koercityvinè jèga $10^{4}$ kartų mažesnè nei esant ịprastai kristalinei medžiagos struktūrai. Detalès, turinčios amorfintą paviršių, yra atsparios korozijai ir radioaktyviam poveikiui (Ulkar et al. 2010). Kadangi lazerio spindulio pluošto dėmé ant apdirbamo paviršiaus yra nedidelių matmenų, paviršiams amorfinti geriau tinka nuolatinės nei impulsinès veikos lazeriai (Zaeh et al. 2011).

Paviršiaus plakiravimas - tai paviršiaus, padengto specialia pasta, milteliais ar kietais komponentais, perlydymas, suteikiant jam specifinių savybių. Plakiravimo būdai skirstomi pagal tai, kaip ị darbo zoną yra tiekiama paviršių dengianti medžiaga (Bhaduri et al. 2016). Iš dengiamos medžiagos miltelių gali būti suformuojamas sluoksnis ant apdirbamo paviršiaus, kuris yra sulydomas lazeriu apsauginių dujų aplinkoje ir sudaro paviršių dengiantị sluoksnị. Dengiama medžiaga gali būti užtepama ant paviršiaus kaip pasta (rankiniu būdu arba automatizuotai) ir sulydoma lazeriu. Dengiama medžiaga taip pat gali būti automatiškai tiekiama ị lazerio poveikio zoną milteliais kartu su apsauginių dujų srautu (Chavoshi et al. 2017). Taip pat gali būti naudojama dengiamos medžiagos viela, kuri lazerio spindulio pluoštu išlydoma ant dengiamo paviršiaus. 
Dengimas. Lazerinis paviršiaus dengimas (garų nusodinimas) dažniausiai atliekamas taip: lazerine spinduliuote išgarinamos dengimo medžiagos dalelès nusodinamos ant dengiamos medžiagos paviršiaus (Manzirov et al. 2017). Taip gaunamas specifinių savybių turintis paviršius (Gibson et al. 2015).

Taikant ši metodą, galima padengti tiek metalinius, tiek nemetalinius paviršius. Išgarinimo efektyvumui turi įtakos medžiagos laidumas šilumai, lazerinès spinduliuotès atspindžio koeficientas ir kt.

Lazerinis paviršių dengimas naudojamas, kai reikia ant dengiamo paviršiaus sudaryti plonas metalines plèveles, izoliacinès medžiagos sluoksni arba kitokị specifinėmis savybėmis pasižymintį darinị (Manzirov et al. 2017). Garinant miltelius, pirmenybė suteikiama lazeriams, turintiems kuo trumpesnị bangos ilgị. Garinant nemetalinių medžiagų miltelius, dažniausiai naudojami $\mathrm{CO}_{2}$ lazeriai (Gu et al. 2009).

Lazerinis paviršiaus valymas tai efektyvus būdas nešvarumams, nereikalingam medžiagos sluoksniui nuo gaminio paviršiaus šalinti, naudojant lazerio spinduliuotę. Taip valant nepažeidžiamas paviršius, neteršiama aplinka, sutaupoma vandens, kuris paprastai gausiai naudojamas, taikant tradicinius paviršiaus valymo metodus (Chavoshi et al. 2016). Lazerio spidulio pluoštas valomą paviršių paveikia tiesiogiai arba per šviesolaidị. Dažniausiai taikomi du paviršių lazerinio valymo metodai: sausasis ir šlapiasis (Zaeh et al. 2011).

\subsection{Lazerio spindulio pluošto ir inžinerinių medžiagụ sąveika}

Nagrinejjant lazerinès spinduliuotès ir kietụjų kūnų sąveiką būtina ịvertinti pagrindinius optinius reiškinius, svarbius atliekant lazerinị medžiagų apdorojimą. Lazerinès spinduliuotès banga krinta ị kietojo kūno paviršių. Dalis krintančios spinduliuotès atsispindi nuo kietojo kūno paviršiaus, o kita spinduliuotès dalis patenka ị kietajị kūną (1.5 pav.) (Farahmand et al. 2014).

Jei kietasis kūnas spinduliuotę stipriai sugeria, galimas kūno kaitinimas, lydymas ir garinimas, o tai ir yra pagrindinès lazerinio mikroapdorojimo operacijos (Hu et al. 2011). Todèl norint ịvertinti lazerinio mikroapdorojimo poveikị konkrečiai inžinerinei medžiagai, reikia ịvertinti jos atspindị ir sugertị (Gibson et al. 2015).

Lazerio spindulio pluošto bangos atspindys nuo kietojo kūno paviršiaus apibūdinamas atspindžio koeficientu, kuris ịvertina atspindètos ir kritusios galių santykị. Norint apibūdinti kietojo kūno pralaidumą, ịvedamas pralaidumo koeficientas, ịvertinantis perejusios ir kritusios galios santykị (Romano et al. 2015).

Medžiagos atspindžio koeficiento nustatymas lazerinio apdorojimo metu yra labai sudètingas uždavinys. Atspindžio koeficientas yra dinamiškai kintantis 
dydis, priklausantis nuo apdirbamo paviršiaus temperatūros, morfologinių, fizikinių ir cheminių charakteristikų. Apdirbamos medžiagos atspindžio koeficientą galima nustatyti tik apdorojimo metu, kai apdirbamas objektas yra kambario temperatūros arba taikant kompiuterinio modeliavimo programas.

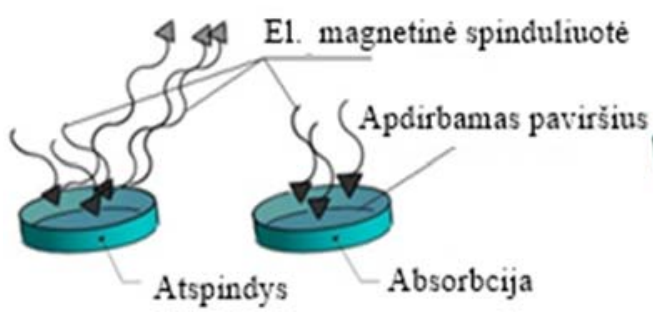

a) b)

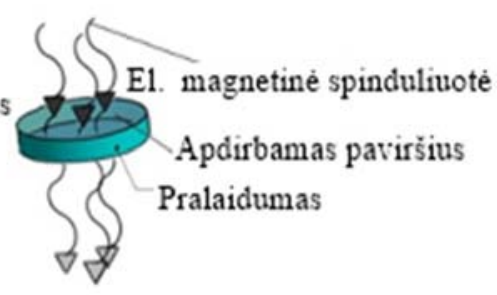

c)

1.5 pav. Lazerinès spinduliuotès sąveika su medžiaga:

a) atspindys; b) sugertis; c) pralaidumas (Chroma)

Fig. 1.5. The interaction of the laser radiation and the material:

a) reflection; b) absorbtion; c) transition

Lazerio spindulio pluošto sugertis kietame kūne, kaip ir kiekvienoje terpeje, yra apibūdinama terpès sugerties koeficientu, kuris įvertina sugertos galios kiekị vienetiniame terpès ilgyje.

Medžiagos sugerties koeficientas labai priklauso nuo spinduliuotès bangos dažnio ir ilgio, todèl tam tikro bangos ilgio spinduliuotę medžiaga gali stipriai sugerti, o kito bangos ilgio - praleisti su labai mažais nuostoliais (Sugioka et al. 2013). Terminis lazerinis apdorojimas galimas tik stipriai sugeriančių inžinerinių medžiagų.

Pagrindinės medžiagos optinès savybės lengvai nustatomos esant mažam šviesos intensyvumui, kai elektronų ir atomų būsena dẻl sąveikos su šviesa nèra stipriai pakitusi (Kumar et al. 2007). Tačiau žinoma, kad galinga lazerio spinduliuote keičia daugelio medžiagų optines savybes ir kartais labai stipriai (Zhang et al. 2007). Todèl lazerio spinduliuotès ir medžiagos sąveikai aprašyti neužtenka statinių dielektrinių funkcijų, o reikia atsižvelgti ị dinamini parametrų kitimą (Shaeffer 2012). Dèl tokio dinaminio parametrų kitimo sugertos spinduliuotès kiekis gali skirtis nuo teorinių reikšmių (Yu et al. 2010).

Visus lazerio spindulio pluošto sukeltus kietujų kūnų optinių savybių pokyčius galima priskirti prie vieno iš triju pokyčio mechanizmų (Dahotre et al. 2011). Didejjant lazerio spinduliuotès intensyvumui, šie pokyčio mechanizmai kinta ir juos galima išdestyti tokia tvarka:

- Medžiagos ir laisvų elektronų tankio kitimas. 
- Laisvų krūvininkų optinè generacija dèl tarpjuostinių šuolių ar staigios jonizacijos dielektrikuose ir puslaidininkiuose.

- Daugiafotonè sugertis dèl intensyvaus lazerio pluošto elektrinio lauko poveikio.

Kintant metalo temperatūrai, vyksta tam tikri reiškiniai, kurie susiję su metalų sugerties koeficiento kitimu (Gurr et al. 2016).

Svarbiausia lazeriu ypatybè, naudojama apdorojant medžiagas, yra jų galimybè sudaryti pasirinktame apdorojamo paviršiaus taške labai didelị spinduliuotès intensyvumą, kuris yra sunkiai pasiekiamas kitais optiniais būdais (Ulkar et al. 2010). Taip galima gauti labai greitą mažos srities kaitinimą (Purtonen et al. 2014).

\subsubsection{Lazerio spidulio pluošto poveikis apdirbamo metalo paviršiui}

Kai lazerio spidulio pluošto energija pasiekia $10^{5} \mathrm{~W} / \mathrm{cm}^{2}$ vertę (bendroji reikšmè plienams) (Balachninaitè et al. 2008), apdirbamo ploto temperatūra pakyla virš lydymosi taško. Prasideda lazerinio lydymo procesas. Apdirbamos zonos temperatūra pakyla didinant poveikio laiką. Dažniausiai, siekiant sumažinti paviršinio sluoksnio mikronelygumų aukštį bei defektų skaičių, lazerinis lydymas atliekamas tiesiogiai apdirbant darbini paviršių.

Kai apdirbamo ploto paviršiaus temperatūra priartejja prie virimo temperatūros, tolesnis ịvedamos i ploto vienetą energijos didinimas nutraukia medžiagos lydymą palaipsniui procesui pereinant ị garavimą (1.6 pav.) (Gibson et al. 2015). Lazerinis medžiagos garinimas vyksta ne iš paviršinio apdirbamo ploto, bet iš sluoksnio, esančio žemiau nei išorinis detalès / gaminio sluoksnis.

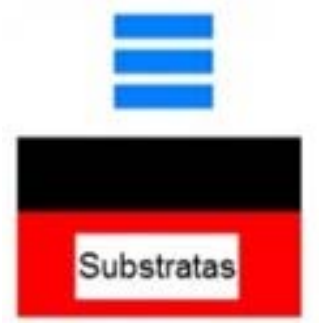

a)

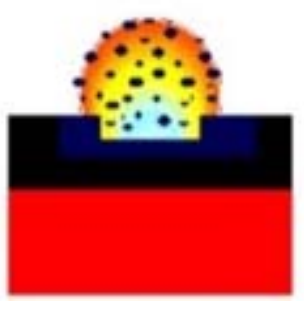

b)

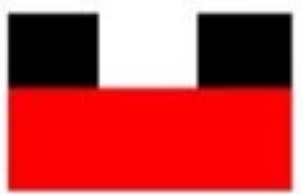

c)

1.6 pav. Lazerinis paviršinio medžiagos sluoksnio garinimas: a) Impulsinės veikos lazerio pluoštas; b) Garinimas; c) Po lazerinio garinimo (Innovative manufacturing technology)

Fig. 1.6. Laser vaporization of top layer of the surface: a) The beam of the pulse laser;

b) Vaporization; c) After laser vaporization 
Dauguma medžiagų, veikiamų didelès energijos, skyla ị sudedamąsias dalis arba išskiria tam tikras medžiagas, degimo produktus ir kt. (Long et al. 2015). Vyksta medžiagos disociacijos procesas. Disociacijos sparta arba efektyvumas priklauso nuo apdirbamos medžiagos, vertinamos kaip termodinaminè sistema, charakteristiku. Disociacijos metu apdirbamo ploto paviršiuje atsiranda atatrankos slègis.

Paviršiaus absorbuotas energijos kiekis bei temperatūra tiesiogiai veikia atatrankos slègi, kuris yra kritinis faktorius šalinant apdirbamo sluoksnio medžiagą lazerinio mikroapdorojimo metu (Gu et al. 2009).

Kai lazerio spindulio pluošto energijos tankis viršija kritinę ribą $\left(10^{5} \mathrm{~W} / \mathrm{cm}^{2}\right)$, medžiaga yra nepertraukiamai garinama. Šio proceso metu vyksta labai sparti paviršinio sluoksnio jonizacija ir formuojasi plazma, kuriai būdingas iki $500 \mathrm{MPa}$ slègis bei apdirbamo kūno paviršiaus temperatūra siekia daugiau nei $5000 \mathrm{~K}$ (1.7 pav.) (Balachninaitè et al. 2008).

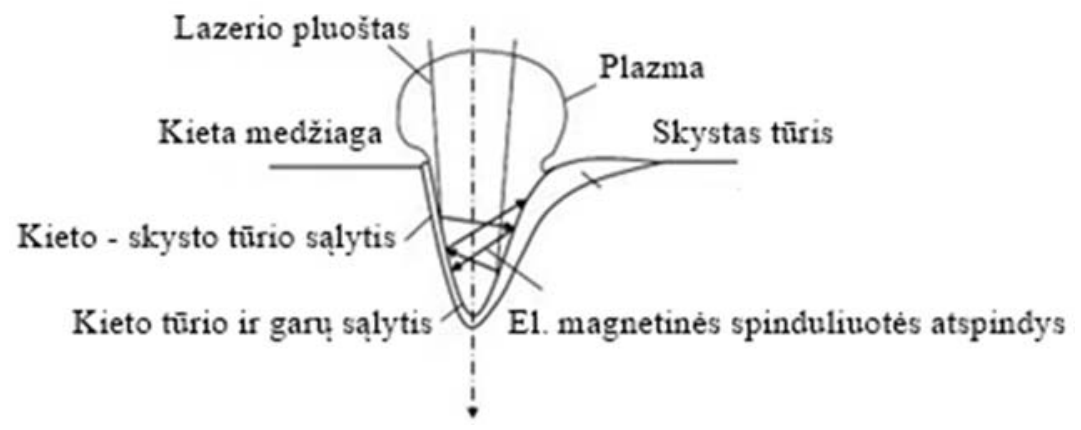

1.7 pav. Plazmos gaubtas virš lazeriu apdorojamo paviršiaus (Innovative manufacturing technology)

Fig. 1.7. Plasma shield above processing area

Susiformavęs plazmos srautas sumažina energijos kiekị, kuri gauna medžiagos apdirbamasis plotas, kai pastarojo temperatūra viršija kritinę ribą (Purtonen et al. 2014).

Plazmos srautas atlieka apsauginio ekrano vaidmenị. Tačiau dažniausiai plazmos formavimas apdirbamo ploto paviršiuje nèra pageidautinas dèl lazerinio proceso metu vykstančio apdorojimo efektyvumo sumažèjimo (Gillner et al. 2005). Dèl šios priežasties apdirbamo ploto jonizacijos laipsnis yra griežtai kontroliuojamas parametras (Bhaduri et al. 2016).

Keičiant ịvedamos energijos kiekị, galima gauti skirtingus lazerinio apdorojimo metodus, besiskiriančius tarpusavyje savo fizikine prigimtimi (1.1 lentelè) (Demir et al. 2014). Prieš tai išvardyti mikrolazerinio apdorojimo metodai yra 
pateikiami kaip atskiri būdai, būtina suprasti, kad riba, kai vienas procesas keičia kitą, yra labai siaura.

1.2 lentelė. Pagrindiniai mikrolazerinio apdorojimo procesai (Balachninaitè et al. 2008)

Table 1.2. Main processes of the laser microprocessing

\begin{tabular}{|l|l|l|l|l|}
\hline $\begin{array}{c}\text { Energijos tankis, } \\
\mathrm{W} / \mathrm{cm}^{2}\end{array}$ & \multicolumn{1}{|c|}{$\mathrm{Iki} 10^{4}$} & $10^{4}-10^{5}$ & $10^{5}-10^{6}$ & $10^{6}-10^{7}$ \\
\hline $\begin{array}{l}\text { Mikrolazerinio } \\
\text { apdorojimo pro- } \\
\text { cesas }\end{array}$ & Kaitinimas & Lydymas & Garinimas & $\begin{array}{l}\text { Ekranuojanti } \\
\text { plazma }\end{array}$ \\
\hline
\end{tabular}

Darbo metu pastebėta, kad energetinès mikrolazerinio apdorojimo reikšmès, pateikiamos literatūroje (Balachninaitè et al. 2008; Mishra et al. 2015; Chavoshi et al. 2016), skiriasi nuo reikšmių gautų šio darbo eksperimentiniuose tyrimuose. Šiuo atveju didelę ịtaką turi lazerinès spinduliuotè ir apdirbamos medžiagos tarpusavio sąveika. Labai svarbu suprasti, kad ne vien spiduliuotès charakteristikos, bet ir apdirbamo paviršiaus parametrai veikia lazerio mikroapdorojimą bei jo efektyvumą.

Lazerio spindulio pluošto ir apdorojamo paviršiaus sąveikos trukmė yra labai svarbus parametras, lemiantis lazerinès spinduliuotès poveikị medžiagai. Lazerinès spinduliuotès sugèrimą lemia sąveika su apdirbamoje medžiagoje esančiais elektronais. Sugèrę spinduliuotės kvantą elektronai peršoka ị aukštesnị sužadintą lygmenį. Sugerta energija virsta gardelès virpesių energija, t. y. šiluma (Sovizi et al. 2005). Lazerinę spinduliuotę galima nagrinèti kaip šilumos šaltinị, esantị detalès paviršiuje arba arti jo (Bhaduri et al. 2016). Parenkant paviršiaus apdorojimo būdą, reikia atsižvelgti ị šias svarbiausias lazerinès technologijos taikymo ypatybes (Gibson et al. 2015):

- Sufokusuoto lazerio spindulio pluošto galios tankis yra didesnis nei daugelio kitų žinomų kaitinimo šaltinių.

- Lazerio spindulio pluoštu galima paveikti nedidelę apdirbamos detalès sritị $(0,1 \mu \mathrm{m}$ ir mažesnę), todèl galima apdirbti labai preciziškai. Tai labai svarbu apdirbant medžiagas, linkusias ị fazinius virsmus.

- Lazerio spindulio pluošto energija yra didelè, todèl apdorojimas trunka daug trumpiau nei kitais būdais. Pavyzdžiui, suvirinimo lazerio spindulio pluoštu greitis 10-20 kartų didesnis negu dujinio suvirinimo.

- Dèl lazerinio proceso lokalumo ir spartos išvengiama liekamujų deformacijų, neiškraipoma detalès geometrija.

- Dèl didelio lazerio spindulio pluošto galios tankio galima apdirbti beveik visas žinomas medžiagas: metalus, nemetalines medžiagas, kietas, trapias, sunkiai lydomas ir kitas. 
- Lazerio spindulio pluoštą galima nukreipti iš vienos darbo vietos ị kitą tuo pačiu didinant įrenginio naudingumo koeficientą. Naudojant optines ir veidrodines sistemas, galima apdirbti sunkiai pasiekiamas vietas.

- Lazerio spindulio pluoštas, palyginti su elektronų spindulio pluoštu, kurio technologinès galimybès analogiškos, yra pranašesnis tuo, kad nereikia vakuumo kamerų.

- Kadangi lazerio spindulio pluošto poveikis yra bekontaktis, technologinis procesas yra ,chemiškai švarus“.

- Procesas gali būti visiškai automatizuotas.

\subsubsection{Faziniai virsmai lazerio spindulio veikiamo metalo paviršiuje}

Keičiant lazerinès spinduliuotès pluošto galią, poveikio trukmę, energijos tankị ir kt., galima nesunkiai keisti pagrindinius mikrolazerinio apdorojimo procesus (Sovizi et al. 2005). Remiantis darbe atlikta analize, lazerinio proceso našumas labai priklauso nuo apdorojimo proceso parametrų bei apdorojamos medžiagos paviršinio sluoksnio geometrinių ir fizikinių charakteristikų. Perejjimą nuo vieno mikrolazerinio apdorojimo proceso prie kito lemia skirtingas energijos kiekis, suteiktas ploto vienetui (Zhu et al. 2016). Tai lemia paviršinio sluoksnio morfologiją bei mechaninių charakteristikų pokytị. Todẻl visiškai aišku, kad būtina nustatyti lazeriu apdirbamo paviršiaus struktūrinių pokyčių principus.

Metalui pereinant iš vienos polimorfinès modifikacijos ị kitą, šiluma sugeriama (kaitinant) arba išskiriama (aušinant). Tam reikalingas atitinkamo dydžio perkaitinimas / peraušinimas lyginant su pradine būsena (Valiulis 2008). Fizikiniams ir struktūriniams pokyčiams tirti naudojamos lydinių būsenos diagramos. Plieno terminio apdorojimo procesas prasideda kaitinant termiškai stabilaus austenito srityje. Užgrūdinto plieno savybès priklauso nuo kaitinimo temperatūros, trukmès ir aušinimo greičio (Valiulis 2005). Didelę reikšmę turi pradinis medžiagos apdorojimas. Labai sunku nustatyti austenizacijos kinetines sąlygas, esant lazeriniam poveikiui (Balachninaite et al. 2008).

Terminio poveikio rezultatas priklauso nuo austenito virsmo produktų savybių auštant (grūdelių dydis, vienalytiškumo laipsnis). Pliene gali susiformuoti dviejų tipų ribinè struktūra: stambiagrūdè ir smulkiagrūdè. Lazeriniam grūdinimui būdingas didelis perkaitinimas, staigus aušinimas, todèl esant stambiagrūdžei plieno mikrostruktūrai, gali susiformuoti terminiai įtrūkiai. Visa tai lemia, kad lazerinį apdorojimą geriau taikyti smulkiagrūdès mikrostruktūros plienui.

Atliekant eksperimentus, pastebèta, kad (Mishra et al. 2015):

- Lazerinio poveikio metu austenizacija vyksta greičiau nei toje pačioje temperatūroje kaitinant ruošinius aukšto dažnio srove ar krosnyje. 
- Vienkartinio poveikio impulsai labai trumpi, todèl metalo fazès nespejja difuziškai sąveikauti.

Lazerinio apdorojimo metu, greitai auštant bandiniui, vyksta nedifuziniai virsmai. Kubinè centruoto paviršiaus austenito gardelè virsta iškreipta centruoto tūrio martensito gardele (Ulkar et al. 2010). Tačiau ne visas austenitas virsta martensitu, todèl grūdintuose plienuose visada yra liekamojo austenito.

\subsection{Pirmojo skyriaus išvados ir disertacijos uždavinių formulavimas}

1. Atlikta išsami adityviosios gamybos, SLS technologijos ypatumų analizè. Nustatyta, kad selektyviajam lazeriniam sukepinimui netaikomi su gaminio geometrija susiję apribojimai. Atlikta AG ir tradicinių metalinių paviršių apdorojimo būdų lyginamoji analizè. Nustatyta, kad AG atveju technologinių operacijų skaičius, laiko bei ekonominès sąnaudos yra daug mažesnès negu tradicinio apdorojimo atveju.

2. Nustatyta, kad sukepinti SLS gaminiai pasižymi dideliu paviršiaus šiurkštumu, mažu atsparumu dilimui. Todèl vienas iš pagrindinių SLS technologijos trūkumų yra būtinas sukepintų gaminių tolesnis mechaninis arba kitoks apdorojimas. Viena iš tokių perspektyvių sukepintų gaminių tolesnio apdorojimo technologijų gali būti lazerinio mikroapdorojimo technologija.

3. Atlikta išsami lazerio poveikio metalams analizè. Nustatyta, kad apdorojimo lazeriu kokybe ir našumas priklauso nuo šių parametrų: lazerio pluošto bangos ilgio, energijos tankio, kritimo kampo, impulsų generavimo dažnio ir poveikio trukmès, apdorojimo greičio, lazerio tipo, apdorojamo paviršiaus geometrinių ir fizikinių charakteristikų.

4. Nustatyta, kad taikant lazerinị apdorojimą, keičiami ne tik detalès geometriniai parametrai, bet ir modifikuojamas paviršius, keičiamos mechaninès, fizikinès ir cheminès apdorojamo paviršiaus charakteristikos. Tai leidžia prognozuoti, kad lazerinis mikroapdorojimas gali būti efektyviai pritaikytas siekiant modifikuoti (kompleksiškai pagerinti) Fe-Ni-Co miltelių pagrindu SLS sukepintų gaminių darbinių paviršių charakteristikas.

5. Optimalių technologinių lazerinio mikroapdorojimo parametrų nustatymas remiantis vien tik literatūros analize, neịmanomas dèl labai didelio kiekio kintamųų parametrų, turinčių ịtaką medžiagų lazeriniam 
mikroapdorojimui. Todèl būtini kompleksiniai, eksperimentiniai tyrimai, kurie leistų nustatyti gaminių, sukepintų selektyviuoju SLS būdu, paviršinio sluoksnio lazerinio modifikavimo proceso poveikị sluoksnio formavimosi procesui ir jo fizikinėms bei eksploatacinėms savybėms.

Darbo tikslui pasiekti būtina spręsti šiuos uždavinius:

1. Ištirti Fe-Ni-Co miltelių pagrindu sukepintų gaminių morfologiją, topografiją ir kitas charakteristikas.

2. Ištirti lazerinio mikroapdorojimo koncentruotosios energijos spindulio pluošto technologinių parametrų poveikị sukepintų SLS sluoksnių morfologijai, topografijai, fizikinèms, mechaninèms savybėms ir cheminei sudèčiai.

3. Nustatyti optimalius lazerinio mikroapdorojimo technologinius parametrus, siekiant gauti geriausių eksploatacinių savybių daugiafunkcị paviršių Fe-Ni-Co miltelių pagrindu. 



\section{2}

\section{Naudotos medžiagos ir sukepinto miltelinio geležies-nikelio-kobalto pagrindo paviršiaus tyrimo metodai}

Darbe taikomi tyrimo metodai parinkti siekiant nustatyti koncentruotosios energijos šaltinio technologinių parametrų pokyčio poveiki apdirbamo paviršiaus kokybinėms charakteristikoms.

Skyriaus tematika paskelbti du autoriaus (su bendraautoriais) straipsniai (Markovič et al. 2016a; Markovič et al. 2016b).

\subsection{Tyrimams naudotos medžiagos}

Sukepintam tūriui sudaryti panaudoti Fe-Ni-Co pagrindo milteliai (2.1 lentelè). Medžiaga pasirinkta atsižvelgiant i plačias šios medžiagos panaudojimo galimybes polimerų liejimo įrangos gamyboje.

Prieš atliekant lazerinio mikroapdorojimo įtakos sukepintų bandinių morfologijai analizę, atlikti sukepinimo miltelių morfologijos tyrimai (2.1 pav.). 


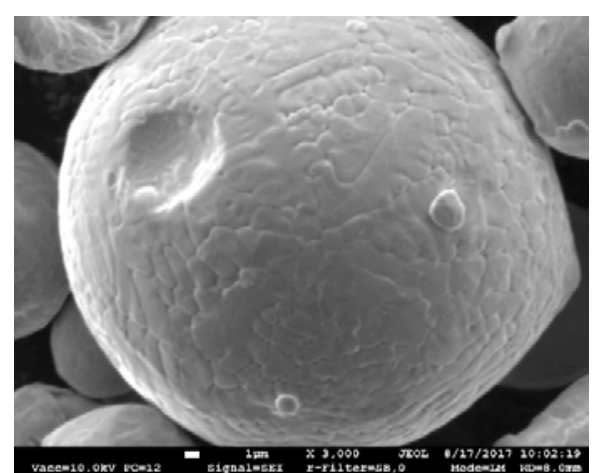

a)

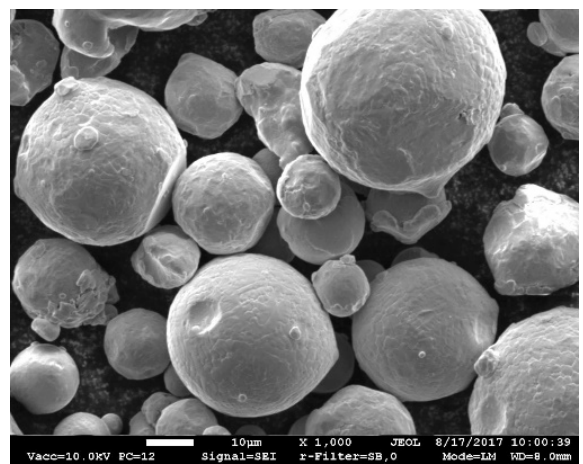

b)

2.1 pav. Sukepinimui naudojamų miltelių morfologija:

a) pirminès kristalizacijos struktūra; b) miltelių dalelių dariniai

Fig. 2.1. The morphology of powder usable for sintering a) the structure of the primary crystalization; b) formations of the powder particles

Selektyviojo lazerinio sukepinimo miltelių analizė parodè, kad miltelių frakcijos dydis svyruoja nuo 7 iki $30 \mu \mathrm{m}$. Miltelių dalelès yra netaisyklingos geometrinès formos (2.1 pav.). Dalelių paviršiuje galima matyti dentritinę pirminès kristalizacijos struktūrą (2.1 pav., a). Miltelių dalelių dalị sudaro dariniai, kurie susideda iš stambios dalelès ir kelių dispersiškai smulkių, prilipusių frakcijų (2.1 pav., b).

2.1 lentelė. Miltelių cheminè sudètis pagal gamintojo specifikaciją, masės \%

Table 2.1. Chemical composition (in wt. \%) of the powder

\begin{tabular}{|c|c|c|c|c|c|c|c|c|}
\hline $\mathrm{Fe}$ & $\mathrm{C}$ & $\mathrm{Si}$ & $\mathrm{Mn}$ & $\mathrm{Ni}$ & $\mathrm{Mo}$ & $\mathrm{Ti}$ & $\mathrm{Co}$ & $\mathrm{Al}$ \\
\hline Likęs & 0,03 & iki 0,1 & iki 0,1 & $17-19$ & 4,8 & iki 0,8 & $8,5-9,5$ & iki 0,1 \\
\hline
\end{tabular}

Selektyviojo lazerinio sukepinimo miltelių rentgeno difrakcinė analizè parodè, kad tiriamuosius miltelius sudaro martensitinè struktūra su KCT gardele ir liekamasis austenitas (2.2 pav.). Diagramoje matomi tik ryškios geležies ir geležies nikelio junginio smailès. Tačiau geležies kietasis tirpalas pasižymi didesne gardele, rodančia, kad tai gali būti Mo ir Co turintis junginys. Labiausiai tikètina, kad miltelius sudaro geležies ir nikelio tarpmetalinis junginys. 


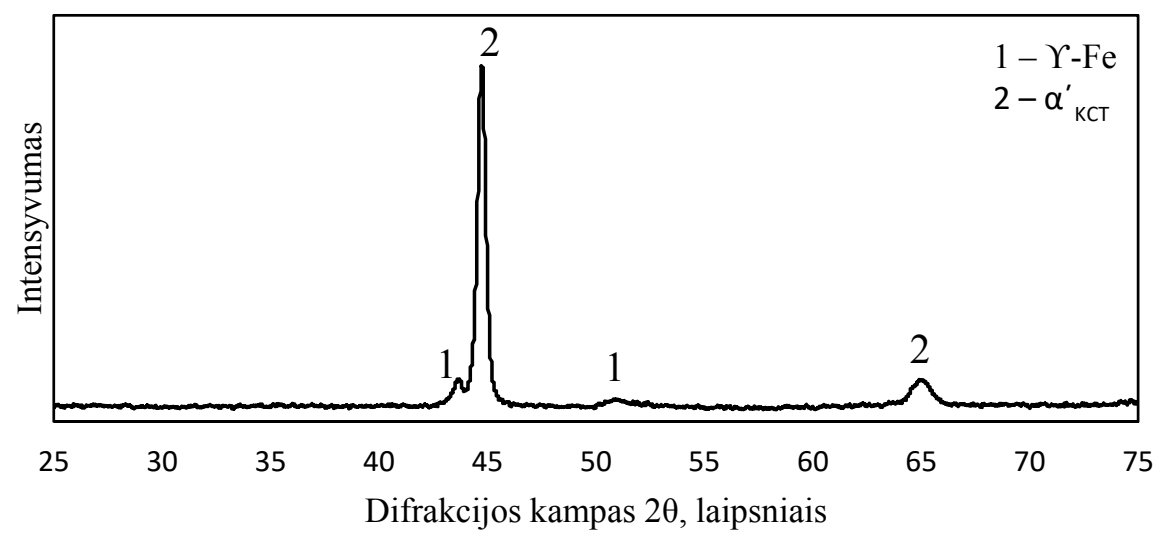

2.2 pav. Fe-Ni-Co miltelių rentgeno difrakcinè kreivè

Fig. 2.2. XRD pattern of the Fe-Ni-Co powder

\subsection{Selektyviojo lazerinio sukepinimo technologijos iranga, parametrai ir charakteristikos}

Miltelinio pagrindo bandinių gamybai panaudotas Concept Laser M3 selektyviojo lazerinio sukepinimo įrenginys. Bandinių sukepinimo metu pagrindinių įrenginio technologinių parametrų keitimas yra neįmanomas dèl gamintojo nustatytų apribojimų, siekiant užtikrinti ịrenginio našumą bei gaminamos produkcijos kokybę. Technologiniai selektyviojo lazerinio sukepinimo parametrai pateikiami 2.2 lentelèje. Sukepintam tūriui atskirti nuo substrato buvo panaudotos vielinės elektroerozijos staklès „Charmille cut 200“. Atskirti nuo substrato bandiniai nuvalyti ultragarso vonelèje. Vonelès tūriui užpildyti panaudotas $\mathrm{C}_{3} \mathrm{H}_{8} \mathrm{O}$ tirpalas. Valymo trukmè $15 \mathrm{~min}$. Valymo terpès temperatūra $40^{\circ} \mathrm{C}$.

2.2 lentelè. Selektyviojo lazerinio sukepinimo parametrai

Table 2.2. Conditions of the selective laser sintering

\begin{tabular}{|c|c|c|c|c|c|c|}
\hline \multicolumn{3}{|c|}{ Lazerio } & \multirow{2}{*}{$\begin{array}{c}\text { Sluoksnio } \\
\text { storis, } \\
\text { mm }\end{array}$} & \multirow{2}{*}{$\begin{array}{l}\text { Sukepinimo } \\
\text { greitis, } \\
\mathrm{mm} / \mathrm{s}\end{array}$} & \multicolumn{2}{|c|}{ Apsauginių dujų } \\
\hline $\begin{array}{l}\text { Bangos } \\
\text { ilgis, } \mathrm{nm}\end{array}$ & $\begin{array}{l}\text { Galia, } \\
\text { W }\end{array}$ & $\begin{array}{c}\text { Dèmès } \\
\text { dydis, } \\
\text { mm }\end{array}$ & & & Tipas & $\begin{array}{c}\text { Debitas, } \\
1 / \mathrm{h}\end{array}$ \\
\hline 1064 & 100 & $\varnothing 0,2$ & 0,03 & 0,2 & Argonas & 0,75 \\
\hline
\end{tabular}


Atlikus mikroskopinius sukepintų bandinių tyrimus, nustatyta, kad šoniniai ir viršutiniai sukepintų bandinių paviršiai pasižymi visiškai skirtinga topografija. Šoninio paviršiaus atveju bandinio paviršiuje matomi netvarkingai ir chaotiškai išsidèstę iškilimai (2.3 pav., a). Viršutinio paviršiaus atveju matoma dèsningai susiformavusi fraktūra (2.3 pav., b). Šị esminị skirtumą lemia selektyviojo lazerinio sukepinimo proceso technologiniai ypatumai. Analizè rodo, kad geometriniu požiūriu neapdoroti šoniniai ir viršutiniai paviršiai yra visiškai skirtingi.

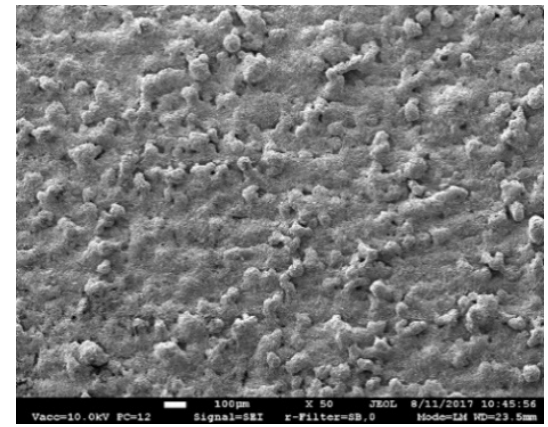

a)

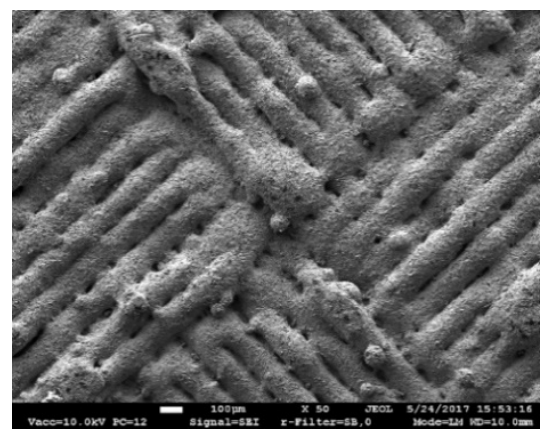

b)

2.3 pav. Sukepintų bandinių topografija: a) šoninis sukepinto bandinio paviršius;

b) viršutinis sukepinto bandinio paviršius

Fig. 2.3. Topographics images of sintered samples: a) lateral sintered surface;

b) top sintered surface

Literatūros šaltiniuose nurodoma (Balachninaitè et al. 2008; Mishra et al. 2015; Farahmand et al. 2014; Shukla et al. 2015; Hu et el. 2011), kad geometriniai apdorojamo paviršiaus rodikliai lemia lazerinio apdorojimo proceso poveikị medžiagai. Siekiant nustatyti optimalius sukepinto bandinio paviršiaus lazerinio mikroapdorojimo parametrus, tikslinga atlikti abiejų, viršutinio ir šoninio, sukepintų paviršių lazerinio mikroapdorojimo eksperimentinius tyrimus.

\subsection{Paviršiaus modifikavimo ịranga ir parametrai}

Sukepintų bandinių paviršių lazeriniam mikroapdorojimui atlikti parinktas nanosekundinès, impulsinès veikos lazeris.

Sukepintas ir atskirtas nuo substrato ruošinys „Charmille cut 200“ elektroerozinio vielinio pjovimo staklemis buvo sudalytas ị vienodus bandinius, kurių matmenys $10 \times 10 \times 10 \mathrm{~mm}$. 2.4 paveiksle languotas plotas vaizduoja lazeriu apdorotą bandinio paviršių. 
Bandinių apdorojimas koncentruotosios energijos šaltiniu buvo atliekamas Fizinių ir technologijos mokslų centre, Lazerinių technologijų mokslinejje laboratorijoje nanosekundinès, impulsinès veikos lazeriu „Baltic HP“. Technologiniai lazerinio įrenginio parametrai pateikiami 2.3 lentelëje.

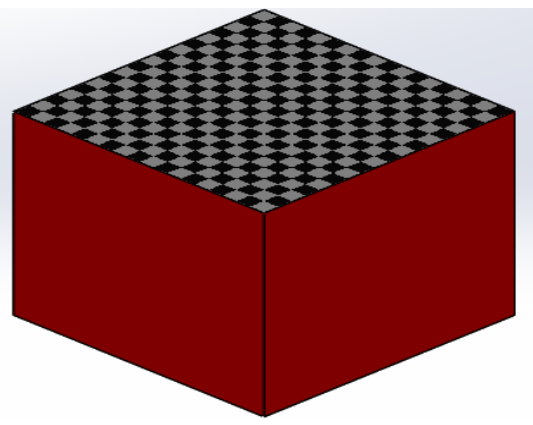

a)

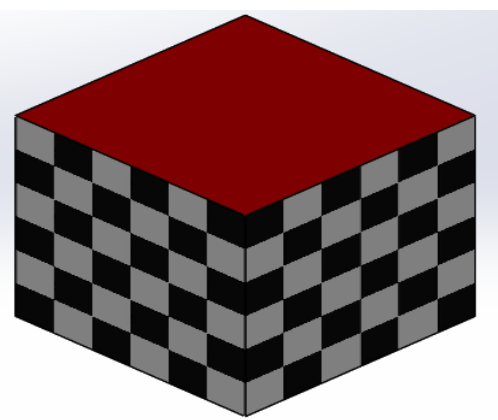

b)

2.4 pav. Sukepinto ir lazeriu apdorojamo bandinio erdvinis vaizdas:

a) viršutinis apdorojamas sukepintas paviršius; b) šoninis apdorojamas sukepintas paviršius

Fig. 2.4. Spatial view of the sintered and laser processed sample:

a) sintered and processed top surface; b) sintered and processed lateral surface

Sukepintam paviršiui būdingas skirtingos krypties didelis paviršiaus netolygumas, formuojasi ryškūs išgaubti aplydymo sluoksniai.

2.3 lentelè. „Baltic HP“ lazerinio įrenginio technologiniai parametrai

Table 2.3. Technical data of the "Baltic HP" laser machine

\begin{tabular}{|l|c|}
\hline \multicolumn{1}{|c|}{ Lazerinės matricos tipas } & Kristalinė \\
\hline Lazerinès matricos medžiaga & Itrio vanadatas $\left(\mathrm{YVO}_{4}\right)$ \\
\hline Aktyvatoriaus medžiaga & 1064 \\
\hline Spinduliuotės bangos ilgis $\lambda, \mathrm{nm}$ & 20 \\
\hline Galia $\mathrm{P}, \mathrm{W}$ & 10 \\
\hline Impulsų generavimo dažnis $v, \mathrm{kHz}$ & 10 \\
\hline Impulso trukme் $\tau, \mathrm{ns}$ & \\
\hline
\end{tabular}

Todèl ịvertinti mikrolazerinio apdorojimo vieno takelio topografiją yra itin sudètinga. Siekiant eliminuoti sukepinto paviršiaus topografijos charakteristiku poveikị lazerinio mikroapdorojimo rezultatams, tikslinga eksperimentinių tyrimų 
pradžioje atlikti lazerinio mikroapdorojimo bandymus ant sukepinto ir papildomai nušlifuoto bandinio paviršiaus.

Sukepintų paviršių lazerinio mikroapdorojimo eksperimentiniai tyrimai suskirstyti ị keturis esminius etapus:

- A eksperimentas - nušlifuoto iki $\mathrm{R}_{\mathrm{a}}=0,2$ viršutinio paviršiaus (2.4 pav., a) dalinis apdorojimas esant dinaminei būsenai, bandiniui suteikiant pastūmą viena kryptimi.

- $B$ eksperimentas - nušlifuoto iki $R_{a}=0,2$ viršutinio paviršiaus (2.4 pav., a) visiškas apdorojimas esant dinaminei būsenai, bandiniui suteikiant pastūmą dviem kryptimis.

- C eksperimentas - sukepinto šoninio paviršiaus (2.4 pav., b) visiškas apdorojimas esant dinaminei būsenai, bandiniui suteikiant pastūmą dviem kryptimis.

- D eksperimentas - sukepinto viršutinio paviršiaus (2.4 pav., a) visiškas apdorojimas esant dinaminei būsenai, bandiniui suteikiant pastūmą dviem kryptimis.

\subsection{Technologiniai eksperimento parametrai}

Lazeriniame mikroapdorojime labai svarbų vaidmeni atlieka energijos E kiekis, suteikiamas plotui S per laiko tarpą t. Siekiant susisteminti lazerinio mikroapdorojimo technologinius parametrus, darbe apskaičiuoti lazerinio apdorojimo ịvedamos energijos lygmenys (2.4 lentelè).

$$
E_{i}=\frac{P}{\mathrm{v}}
$$

čia $E_{i}$ - vieno impulso energija, J; $P$ - lazerio spindulio pluošto galia, W; v impulsų generavimo dažnis, Hz.

$$
E_{i t}=\frac{E_{i}}{d^{2}}
$$

čia $E_{i t}$ - impulso energijos tankis, $\mathrm{J} / \mathrm{cm}^{2} ; d$ - sufokusuoto lazerio spindulio pluošto skersmuo, $\mathrm{cm}$.

$$
E_{i t s}=E_{i t} \cdot v
$$

čia $E_{i t s}$ - energijos kiekis apdorojimo paviršiuje per vieną sekundę, W/ $/ \mathrm{cm}^{2}$.

$$
E=\frac{E_{i t s}+\left(0,7 E_{i t s}\right)}{Z} ;
$$




$$
Z=\frac{V}{V^{\prime}},
$$

čia $E$ - įvedamoji energija $\mathrm{W} / \mathrm{cm}^{2}$ esant apdorojimo greičiui $V^{\prime} ; 0,7 E_{i t s}-$ gretimo ejimo suteikiamas energijos tankis, W/ $\mathrm{cm}^{2} ; V^{\prime}-$ atskaitos greitis, $1 \mathrm{~mm} / \mathrm{s} ; V_{-}$ apdorojimo greitis, $\mathrm{mm} / \mathrm{s} ; Z$ - apdorojimo ir atskaitos greičių matematinis santykis.

2.4 lentelè. Lazerinio apdorojimo ịvedamos energijos $\mathrm{W} / \mathrm{cm}^{2}$ ị bandinio paviršių skaičiavimo rezultatai

Table 2.4. The results of calculation of input energy at specimen surface laser processing, $\mathrm{W} / \mathrm{cm}^{2}$

\begin{tabular}{|c|c|c|c|c|c|c|}
\hline \multirow{2}{*}{$\begin{array}{c}\text { Apdorojimo } \\
\text { greitis v, mm/s }\end{array}$} & \multicolumn{6}{|c|}{ Ivedamos energijos tankis W/cm², esant skirtingai } \\
& 1 & 2 & 2,5 & 3 & 3,5 & 4 \\
\hline & 265306 & 530612 & 663265 & 795918 & 928571 & 1061224 \\
\hline 1 & 106122 & 212245 & 265306 & 318367 & 371429 & 424490 \\
\hline 2,5 & 53061 & 106122 & 132653 & 159184 & 185714 & 212245 \\
\hline 5 & 35374 & 70748 & 88435 & 106122 & 123810 & 141497 \\
\hline 7,5 & \multicolumn{7}{|c|}{} \\
\hline
\end{tabular}

2.5 lentelè. Lazerinio apdorojimo ịvedamos energijos $\mathrm{W} / \mathrm{cm}^{2}$ lygmenys

Table 2.5. The levels of input energy for laser processing

\begin{tabular}{|c|c|c|c|c|c|}
\hline \multirow{2}{*}{$\begin{array}{c}\text { Apdorojimo } \\
\text { greitis v, } \\
\mathrm{mm} / \mathrm{s}\end{array}$} & \multicolumn{4}{|c|}{$\begin{array}{c}\text { Ivedamos energijos tankis } \mathrm{W} / \mathrm{cm}^{2} \text {, esant skirtingai } \\
\text { apdorojimo galiai } \mathrm{P}, \mathrm{W}\end{array}$} & \multirow{2}{*}{$\begin{array}{c}\text { Ivedamos } \\
\text { energijos } \\
\text { lygmuo }\end{array}$} \\
\hline & 2 & 2,5 & 3 & 3,5 & \\
\hline 1 & 530612 & 663265 & 795918 & 928571 & E3 \\
\hline 2,5 & 212245 & 265306 & 318367 & 371429 & E2 \\
\hline 5 & 106122 & 102041 & 122449 & 142857 & E1 \\
\hline
\end{tabular}

Lazerio spindulio pluošto dėmès plotas bandinio paviršiuje $d=25 \mu \mathrm{m}$. Dèmès plotas visų bandymų metu nebuvo keičiamas.

Ekperimento tyrimų etapų A-D technologinių parametrų reikšmės pateiktos antrame priede.

B, C ir D eksperimentų metu sanklotos reikšmè nebuvo keičiama. Sanklota, tai lazerio spindulio pluošto atstumas tarp dviejų gretimų èjimų, kuris apskaičiuojamas pagal 2.6 formulę:

$$
\text { Sanklota }=d \times 0,7,
$$


čia $d$ - lazerio spindulio pluošto dèmès plotas bandinio paviršiuje, $\mu \mathrm{m} ; 0,7$ koeficientas sanklotos dydžiui nustatyti. Sanklotos reikšmė pasirinkta remiantis literatūros analize. Šị parametrą taip pat galima vadinti skenavimo žingsniu.

Lazerinis paviršiaus apdorojimas atliktas esant dinaminei būsenai, bandiniui suteikiant pastūmą dviem kryptimis. Visi lazeriu apdoroti bandiniai, prieš pradedant instrumentinius tyrimus, nuvalyti ultragarso vonelëje.

\subsection{Eksperimentinio tyrimo metodika}

Darbe atlikti kompleksiniai sukepinto ir koncentruotosios energijos šaltiniu apdoroto paviršiaus tyrimai. Jų metu analizuota sukepinto ir koncentruotosios energijos šaltiniu apdoroto paviršiaus makro ir mikrostruktūra, cheminè sudėtis. Atlikti eksperimentinių bandinių mikrokietumo, paviršinio sluoksnio mikronelygumų tyrimai. Ištirtos tribologinès paviršių savybès. Atlikti korozijos tyrimai.

\subsubsection{Optinè mikroskopija}

Optinès mikroskopijos tyrimai atlikti analitiniu mikroskopu NIKON MA200, aprūpintu integruota vaizdo kamera ir programiniu duomenų apdorojimo paketu. Mikrostruktūra tirta naudojant 10 ir 20 kartų didinimą.

Metalografiniams tyrimams atlikti bandiniai buvo itvirtinti plastikinèse formose, o tarpas tarp formos ir bandinio buvo užpildomas epoksidine derva. Mikrošlifams paruošti atliktas paviršinio bandinių sluoksnio poliravimas, naudojant skirtingo grūdètumo popieriu nuo P100 iki P2000. Tolesnis tiriamų paviršių poliravimas buvo atliekamas, naudojant poliravimo pastas, kurių grūdètumas nuo 3 iki $1 \mu \mathrm{m}$. Poliravimo našumui padidinti naudota KEMET gamintojo poliravimo suspensija. Po poliravimo šlifai nuplauti etilo alkoholio tirpalu ir džiovinti karšto oro srove. Bandinių mikrostruktūra tirta dviem etapais: po poliravimo ir po ėsdinimo. Ėsdinimui buvo naudojamas tirpalas sudarytas iš šių elementų: vandens: (1 dalis), acto rūgšties (1 dalis), druskos rūgšties (4 dalis) ir azoto rūgšties (1 dalis). Optinès mikroskopijos būdu nustatytas lazerinès spinduliuotès paveikto ploto gylis bei mikrostruktūra.

\subsubsection{Skenuojamoji elektroninè mikroskopija ir rentgeno mikroanalizè}

Skenuojamosios elektroninès mikroskopijos (SEM) tyrimai atlikti Vilniaus Gedimino technikos universiteto Termoizoliacijos mokslo instituto Statybinių medžiagu laboratorijoje. Tyrimai atlikti SEM JEOL JSM-7600F skenuojamosios elektroninès mikroskopijos prietaisu su antrinių elektronų SE detektoriumi. 
Elektroninès mikroskopijos parametrai: greitinančioji įtampa $10 \mathrm{kV}$, atstumas iki bandinio paviršiaus $11 \mathrm{~mm}$, padidinimas nuo 50 iki $1000 \mathrm{kartų,} \mathrm{temperatūra}$ $22{ }^{\circ} \mathrm{C}$.

Sukepinti ir lazeriu apdoroti bandinių paviršiai tirti SEM būdu antrinių elektronų signalu. Bandinių paviršiai buvo chemiškai nuvalyti $\mathrm{C}_{3} \mathrm{H}_{8} \mathrm{O}$ tirpalu, norint pašalinti ịvairius paviršiaus nešvarumus. Papildomai analizuota žaliavos (miltelių) ir eksperimentinių bandinių cheminè sudètis, taikant rentgeno mikroanalizès metodą (RMA).

\subsubsection{Rentgeno spindulių difrakcijos analizè}

Medžiagu kokybinė fazinès sudèties analizè atlikta SMART LAB (Japonija) rentgeno difraktometru. Rentgeno spinduliuotès spektrui išskirti naudotas grafito monochromatorius. Bandymų parametrai: $9 \mathrm{kV}$ itampa, difrakcijos kampo $2 \theta$ intervalas nuo 20 iki $80^{\circ}$, detektoriaus judèjimo žingsnis $-0,02^{\circ}$. Difraktograma užrašyta $1 \%$ min. greičiu. Bandymas atliktas $22^{\circ} \mathrm{C}$ temperatūroje.

Tyrimai atlikti su sukepinimui naudotais Fe-Ni-Co milteliais, sukepintais ir lazerio spinduliuote apdorotais bandiniais. Visi analizès rezultatai yra pateikiami difrakcinèse kreivėse, kurios rodo atsispindejjusių rentgeno spindulių intensyvumo priklausomybę nuo detektoriaus kampo.

\subsubsection{Paviršiaus šiurkščio matavimas}

Tiriamų sukepintų ir koncentruotosios energijos šaltiniu apdorotų sukepintų bandinių paviršiaus mikronelygumų parametrai nustatyti Vilniaus Gedimino technikos universiteto Mechanikos fakulteto Medžiagotyros ir suvirinimo mokslinejje laboratorijoje naudojant portatyvini profilometrą TR-200, kurio tikslumas $\pm 0,01 \mu \mathrm{m}$.

Matavimai remiasi deimantinès adatos kontaktine sąveika su tiriamu paviršiumi horizontalioje padètyje. Paviršiuje esantys nelygumai sukelia vertikalius adatos poslinkius, kurie interpretuojami kaip paviršiaus nelygumai. Programine iranga apdorojus duomenis, gaunama linija, atvaizduojanti paviršiaus topografiją. Buvo nustatytas koncentruotosios energijos šaltiniu apdorotų - sukepintų paviršių vidutinis mikronelygumų aukštis $R_{a}$.

\subsubsection{Mikrokietumo matavimai}

Tiriamų sukepintų ir koncentruotosios energijos šaltiniu apdorotų sukepintų bandinių mikrokietumo matavimai atlikti Vilniaus Gedimino technikos universiteto Mechanikos fakulteto Medžiagotyros ir suvirinimo katedros mokslinèje laboratorijoje. Mikrokietumas vertintas poliruotuose paviršiuose ir skersiniuose 
mikrošlifuose su Zwick Roell ZH universaliu automatizuotu kietmačiu su $1 \%$ matavimo paklaida. Matavimai atlikti mikrovikerso metodu su $100 \mathrm{~g}$ apkrova ir $10 \mathrm{~s}$ išlaikymo laiku, optinis padidinimas 50 kartų. Suskaičiuotas sukepinto metalo ir koncentruotosios energijos šaltiniu apdoroto sluoksnio mikrokietumo vidurkis iš 10 matavimo rezultatų, atmetant mažiausią ir didžiausią reikšmes.

\subsubsection{Tribologiniai tyrimai}

Tiriamų sukepintų ir koncentruotosios energijos šaltiniu apdorotų sukepintų bandinių atsparumas trinčiai buvo ịvertintas atliekant sausosios trinties bandymą. Bandymai atlikti Vilniaus Gedimino technikos universiteto Mechanikos fakulteto Medžiagotyros ir suvirinimo katedros mokslinejje laboratorijoje bei Baltstogès technikos universiteto Mechanikos fakulteto Medžiagotyros katedroje. Bandymai Baltstogeje atlikti Microtest „Pin-on-disc“, „Ball-on-disc“ tribometru, naudojant tokius eksperimento režimus: slydimo kelias - $200 \mathrm{~m}$, slydimo greitis $300 \mathrm{aps} . / \mathrm{min}$, trajektorijos spindulys $-2 \mathrm{~mm}$, apkrova $-5 \mathrm{~N}$, bandymo temperatūra $-23{ }^{\circ} \mathrm{C}$. Eksperimentiniam tyrimui atlikti pasirinkta „Pin-on-disc“ trinties schema. Indentorius - $3 \mathrm{~mm}$ skersmens grūdintas cilindras, pagamintas iš nerūdijančio plieno 1.4034 .

Bandymai Vilniuje atlikti Microtest „Pin-on-disc“, „Ball-on-disc“ tribomet$\mathrm{ru}$, naudojant tokius eksperimento režimus: slydimo kelias $-400 \mathrm{~m}$, slydimo greitis -300 aps./min, trajektorijos spindulys $-2 \mathrm{~mm}$, apkrova $-5 \mathrm{~N}$, bandymo temperatūra $-23{ }^{\circ} \mathrm{C}$. Eksperimentiniam tyrimui atlikti pasirinkta „Ball-on-disc“ trinties schema. Indentorius - guoliams naudojamas $6 \mathrm{~mm}$ skersmens grūdintas rutuliukas, kuris pagamintas iš AISI52100 nerūdijančio plieno.

Eksperimentinių bandinių atsparumas trinčiai įvertintas lyginant žèmiau pateiktus parametrus prieš ir po trinties bandymų:

- rutuliuko kontakto dèmès geometriją;

- bandinio masès pokytị;

- bandinio kontakto dèmès geometriją.

Svèrimui naudotos analitinès elektroninès svarstyklès „Precisa XR 205SM-

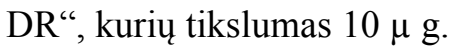

\subsubsection{D optinè profilometrija}

Koncentruotosios energijos šaltiniu apdorotų sukepintų bandinių 3D paviršiaus topografija ir šiurkštis buvo nustatomi naudojant bekontaktị optinị prietaisą. Tyrimas atliktas Fizinių ir technologijos mokslų centre. Pagrindiniai bandymų parametrai: darbinis atstumas $4,7 \mathrm{~mm}$, optinè raiška $0,67 \mu \mathrm{m}^{3}$, skaitmeninè apertūra 0,4 , praktinis maksimalus nuolydis 18,9 laipsnių. Dèl labai mažo koncentruotosios energijos pluoštu apdirbtų paviršių atspindžio eksperimentinių 
bandiniu tiriamieji paviršiai garinimo būdu padengti plona apie $10 \mathrm{~nm}$ storio aukso plèvele. Eksperimentinių bandinių topografija ịvertinta naudojant vidutinị paviršiaus mikronelygumų aukščio parametrą $\mathrm{R}_{\mathrm{a}}$.

\subsubsection{Korozinio atsparumo bandymai}

Koncentruotosios energijos šaltiniu apdorotų sukepintų bandinių atsparumas korozijai ìvertintas potenciodinaminès poliarizacijos matavimu. Eksperimentiniai bandymai buvo atliekami naudojant elektrocheminių matavimų sistemą SOLARTON 1280C (Jungtinè Karalystė). Ją sudaro potenciostatas, galvanostatas, dažniu generatorius ir impedanso spektrų analizatorius. Matavimai atlikti naudojant trijų elektrodų elektrocheminę celę. Platinos viela buvo naudojama kaip pagalbinis elektrodas, o lyginamuoju elektrodu buvo $\mathrm{Ag} / \mathrm{AgCl} / \mathrm{KCl}$. Korozinio atsparumo tyrimai buvo atlikti $0,5 \mathrm{M} \mathrm{Na}_{2} \mathrm{SO}_{4}$ terpeje.

Elektrocheminiai matavimai buvo atliekami po 60 min., nusistovejus korozijos potencialui, skleidžiant potencialą i anodinę ir katodinę pusę. Potencialo sklidimo greitis buvo $10 \mathrm{mV} / \mathrm{s}$. Elektrocheminiai parametrai, tokie kaip korozijos potencialas (Ekor.) ir korozijos srové (j), nustatyti naudojant atitinkamą duomenų apdorojimo programinę įrangą.

\subsection{Antrojo skyriaus išvados}

1. Tyrimo metų nustatyta, kad šoniniai ir viršutiniai sukepintų SLS bandinių paviršiai pasižymi visiškai skirtinga topografija. Šoniniam paviršiui būdingi netvarkingai ir chaotiškai išsidèstę iškilimai, o viršutinio paviršiaus atveju - dèsningai susiformavusi fraktūra.

2. Siekiant ịvertinti selektyviojo lazerinio sukepinimo proceso technologinius ypatumus ir papildomo lazerinio mikroapdorojimo ịtaką sukepinto $\mathrm{Fe}-\mathrm{Ni}$-Co pagrindo paviršiaus charakteristikoms būtina taikyti 4 etapų (A, B, C ir D) eksperimentinių tyrimų metodiką.

3. Skenuojančios elektroninès mikroskopijos ir rentgeno spindulių difrakcijos metodai, paviršinio sluoksnio morfologijos ir nevienalytiškumo analizès, cheminès ir fazinès sudèties bei tribologinių savybių tyrimo, korozinio atsparumo vertinimo bei mikrokietumo matavimo tyrimai leidžia ịvertinti sukepintų Fe-Ni-Co miltelių pagrindu bandinių galutinio greitojo lazerinio paviršiaus mikroapdorojimo režimų poveikị ir ịvertinti jo efektyvumą. 



\section{Sukepintų miltelinio pagrindo paviršių modifikavimo koncentruotosios energijos šaltiniu proceso ir eksploataciniu savybių tyrimai}

Skyriuje pateikiama sukepintų ir koncentruotosios energijos šaltiniu apdorotų paviršių sandaros ir eksploatacinių savybių tyrimų analizè.

Skyriaus tematika paskelbti du autoriaus (su bendraautoriais) straipsniai (Markovič et al. 2015a; Markovič et al. 2016c).

\subsection{Sukepintų ir koncentruotosios energijos šaltiniu apdorotų bandinių topografijos analizè}

Darbe nagrinejama sukepinimui naudotų miltelių bei sukepintų A, B, C ir D eksperimentinių bandinių morfologija. 
A eksperimento metu lazeriu buvo iš dalies nuskenuoti bandiniu paviršiai, siekiant nustatyti geriausius koncentruotosios energijos šaltinio technologinių parametrų derinius bei pastarujų įtaką lazerinio mikroapdorojimo proceso pokyčiui. Literatūros šaltinių analizè parodè, kad efektyviausią eksperimentinių FeNi-Co sukepintų bandinių mikrolazerinį apdorojimą galima pasiekti esant lazerinio garinimo procesui. Lazerinio apdorojimo procesas labai priklauso nuo geometrinių apdorojamo paviršiaus charakteristikų.

A eksperimento metu buvo atliktas bandiniu paviršinio sluoksnio lazerinis apdorojimas, bandiniui suteikiant pastūmą viena kryptimi ir iš dalies apdorojant bandinio plotą. Prieš lazerini apdorojimą bandiniai buvo nušlifuoti iki $R_{a}=0,2 \mu \mathrm{m}$. 3.1 paveiksle matoma medžiagos apdorojimo intensyvumo ir lazerio energijos tankio pokyčio įtaka apdoroto paviršiaus topografijai bei lazeriniam mikroapdorojimo procesui. Analizè atlikta siekiant nustatyti esminius mikrolazerinio apdorojimo procesus bei ịvedamos energijos vertes, kurioms esant stebimas konkretus procesas. 3.1 paveiksle matomas ryškus apdoroto paviršiaus (takelio) topografijos pokytis, kuri lemia skirtingas lazerinio apdorojimo ịvedamos energijos kiekis nuo $35 \mathrm{~kW} / \mathrm{cm}^{2}$ (A1 bandinys) iki $1061 \mathrm{~kW} / \mathrm{cm}^{2}$ (A9 bandinys).

Priklausomai nuo energijos kiekio, suteikto apdorojamo ploto vienetui, gali vykti skirtingi lazerio spindulio pluošto ir apdorojamos medžiagos sąveikos procesai: kaitinimas, lydymas, garinimas ir ekranuojančios plazmos formavimas.

Tyrimų metu nustatyta, kad apdorojant lazeriu (1 ejjimu) SLS būdu sukepintus ir papildomai nušlifuotus bandinius bei keičiant lazerinio mikroapdorojimo parametrus (lazerio galią nuo $1 \mathrm{~W}$ iki $4 \mathrm{~W}$, apdorojimo greiti nuo $1 \mathrm{~mm} / \mathrm{s}$ iki $7,5 \mathrm{~mm} / \mathrm{s}$ ), galimi keturi esminiai lazerinio mikroapdorojimo procesai: kaitinimas, lydymas, garinimas ir ekranuojančios plazmos formavimas. A1 ir A2 bandiniuose, apdorotuose taikant $1 \mathrm{~W}$ galią ir nedidelius 1 ir $2,5 \mathrm{~mm} / \mathrm{s}$ greičius, susiformavo grublèta stambių žvynų su giliais tarpais topografija (3.1 pav., a ir d), kuri būdinga lazerinès abliacijos režimui. A3 ir A4 bandiniuose, kuriuose padidinus apdorojimo greiț buvo sumažintas ịvedamos energijos kiekis, stebima tolygesnè smulkesnių žvynelių topografija (3.1 pav., g ir j) - abliacijos režimas perèjo ị lydymą. A5-A8 bandinių, apdorotų taikant didesnę 2,5 W lazerio galią, morfologija gerokai skiriasi nuo pirmų keturių bandinių. Čia stebimi intensyvaus garavimo pėdsakai (3.1 pav., b, e, h ir k); metalas paviršiuje susikristalizavo i smulkių sferinių granulių pavidalo dalelių sankaupas. A9-A12 bandiniuose, dar labiau padidinus galią ( $4 \mathrm{~W}$ ), suformuoti gilūs grioveliai ir didelès tuštumos tarp garintos medžiagos. Ivvedamos energijos vertems artejant prie $1 \mathrm{MW} / \mathrm{cm}^{2}$ reikšmès kyla pavojus, kad garinant medžiagą apdorojimo metu virš apdirbimo zonos gali susiformuoti ekranuojanti plazma. 


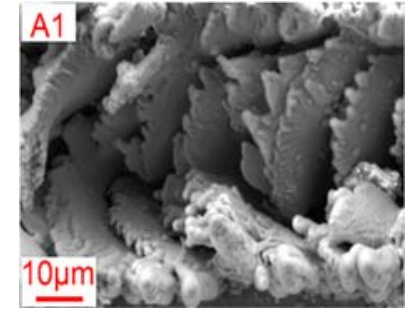

a)

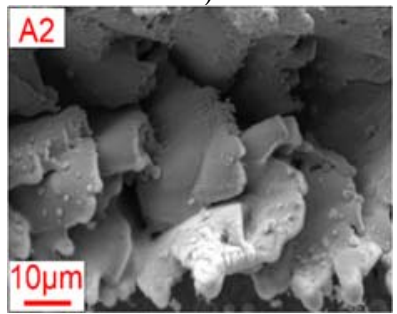

d)

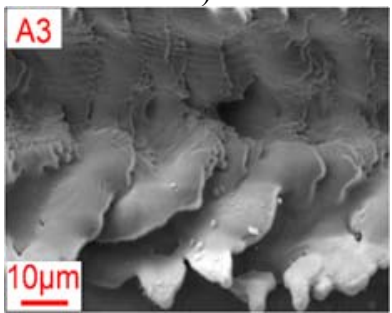

g)

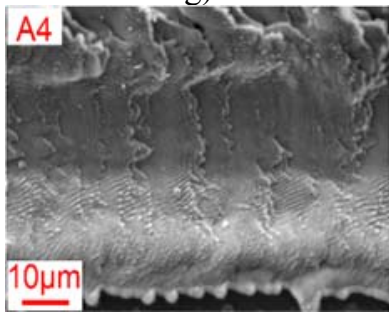

j)

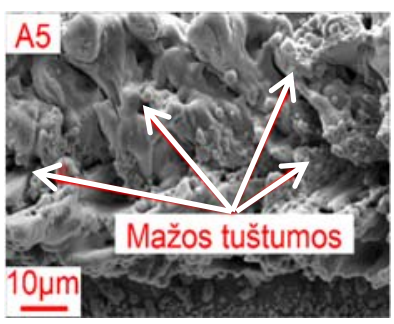

b)

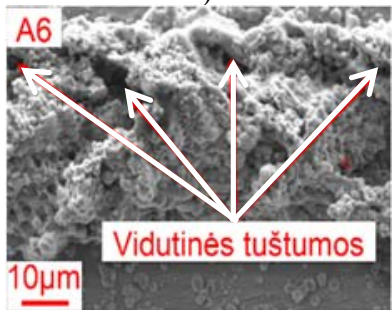

e)

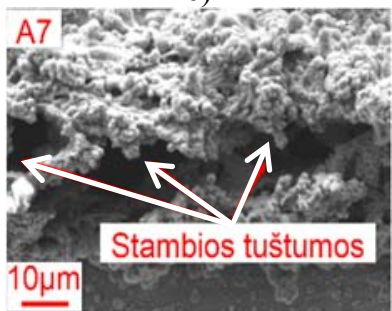

h)

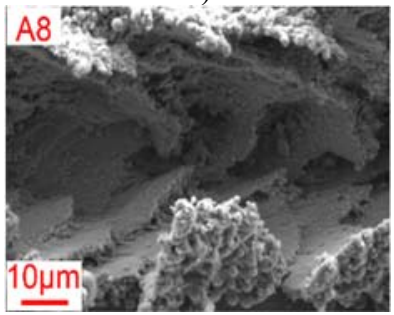

k)

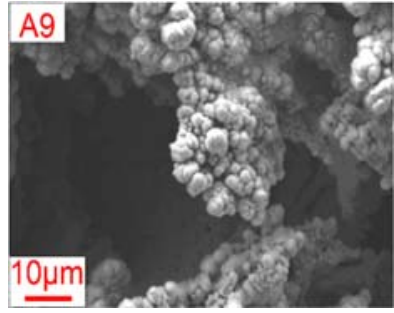

c)

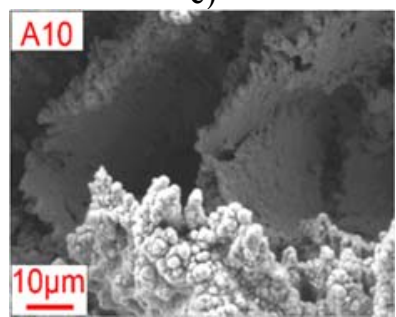

f)

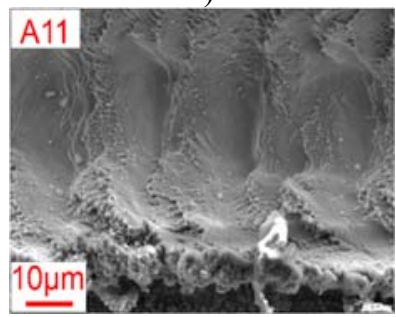

i)

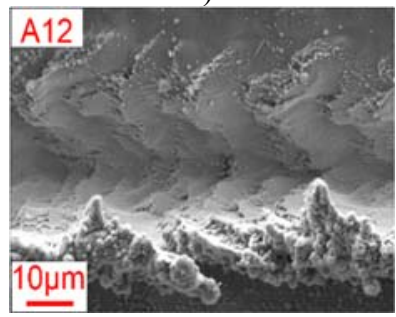

1)

3.1 pav. A eksperimento bandinių lazeriu apdoroto takelio topografija: a) A1; b) A5; c) A9; d) A2; e) A6; f) A10; g) A3; h) A7; i) $\mathrm{A} 11$; j) A4; k) A8; 1) A12

Fig. 3.1. Topographics images of the laser processed pathes of the $A$ experiment samples: a) A1; b) A5; c) A9; d) A2; e) A6; f) A10; g) A3; h) A7; i) $\mathrm{A} 11 ;$ j) A4; k) A8; 1) A12

Lazeriu apdorojant sukepintus paviršius, siekiama pašalinti (išgarinti) ploną paviršinį sukepintą sluoksnị, nepasiekiant ekranuojančios plazmos formavimosi, kuri stipriai sumažintų apdorojimo greitị, proceso efektyvumą ir stabilumą dèl 
dinamiškai kintančios terpès, pro kurią praeina lazerio spindulio pluoštas, lūžio rodiklio pokyčio (Balachninaitè et al. 2008). Todèl, tolesnei analizei buvo pasirinkti A5-A8 bandiniai. Siekiant kokybiškai ịvertinti mikrolazerinio garinimo poveiki paviršiaus topografijai, A5-A8 bandiniai buvo vertinami 5 balų skalëje. Vertinimas atliktas remiantis 3.1 ir 3.2 paveikslų analize.

A5 bandinio paviršinio sluoksnio topografiniuose vaizduose (3.2 pav., a) apdoroto takelio paviršiuje stebimi daugybiniai ịtrūkiai bei vidutinis išgarintos medžiagos dalelių ištaškymas terminio poveikio zonoje. Trūkių atsiradimą lemia vidiniai itempiai, kurie atsirado dèl greito apdorojimo zonos įkaitinimo bei staigaus aušinimo (terminis šokas). A6-A8 bandinių paviršiuose, kurie buvo apdoroti taikant tą pačią $2,5 \mathrm{~W}$ galią ir nuosekliai didinant apdorojimo greiti (2,5 / 5 / $7,5 \mathrm{~mm} / \mathrm{s}$ ) trūkiai nèra matomi dèl mažesnio energijos kiekio, suteikto apdorojimo plotui.

A6 ir A7 bandinių topografija rodo lazerinio mikroapdorojimo, esant greičiui nuo 2,5 iki $5 \mathrm{~mm} / \mathrm{s}$, poveikio panašumą. Tačiau A7 atveju matomos stambios tuštumos (3.1 pav., h) bei vidutinis išgarinto sluoksnio ištaškymas (3.2 pav., c).

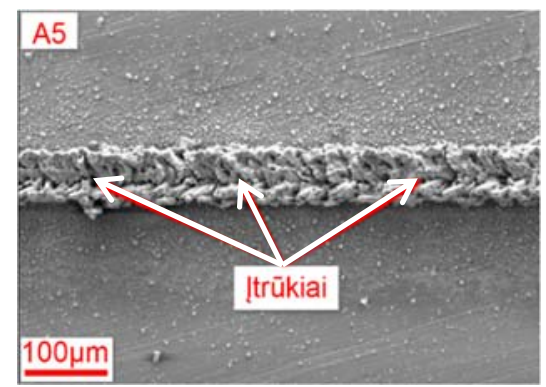

a)

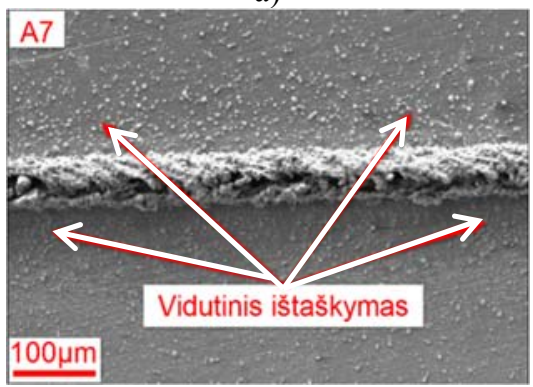

c)

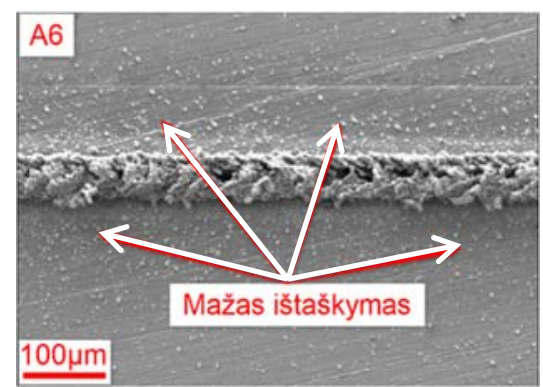

b)

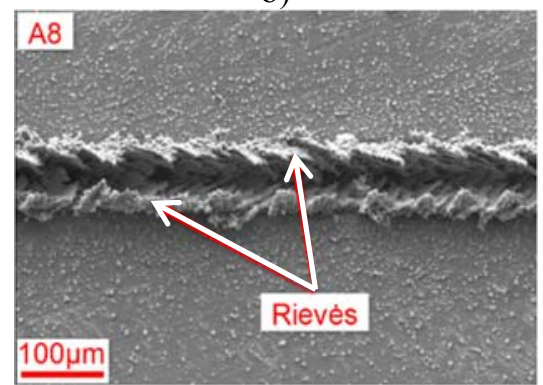

d)

3.2 pav. A eksperimento bandinių paviršiaus topografija: a) A5; b) A6; c) A7; d) A8

Fig. 3.2. Topographics images of the surface of the A experiment samples:

a) A5; b) A6; c) A7; d) A8 
A6 bandinio paviršiuje susiformavo vidutinès tuštumos (3.1 pav., e) ir mažas išgarinto sluoksnio ištaškymas (3.2 pav., b). Medžiagos apdorojimo rezultato skirtumą lemia išlydyto tūrio dinaminio judejimo bei kristalizacijos sparta. A7 bandinio paviršiuje (3.2 pav., c), matomas tankesnis tiškalų išsidèstymas. Defektas atsiranda dèl didesnio lazerinio apdorojimo dinaminių procesų intensyvumo.

Didinant apdorojimo greiti iki 7,5 mm/s (A8 bandinys 3.2 pav., d), stebimas išlydyto bei garinamo tūrio išskyrimas i dvi dalis. Reiškinị lemia vienu metu vykstantis medžiagos lydymo bei garinimo procesas. Esant šiam reiškiniui, visiškai apdirbamo bandinio paviršiuje formuojasi rievès, kurios neigiamai veikia apdorojamo paviršiaus kokybès rodiklius.

Atsižvelgiant ị lazeriniu mikroapdorojimu suformuotų takelių bendrą morfologiją, jų vientisumą, banguotumą, ịtrūkių ir tuštumų dydị bei kiekį, ištaškymo laipsni ir kt., A5-A8 bandiniai buvo įvertinti penkių balų sistemoje (3.1 lentelè). Kuo aukštesnis įvertinimo balas, tuo geresnè paviršiaus topografija.

3.1 lentelè. A5-A8 bandinių kokybès analizès rezultatai

Table 3.1. The results of the quality analyse, samples A5-A8

\begin{tabular}{|c|c|c|c|c|}
\hline \multirow{2}{*}{} & \multicolumn{4}{|c|}{ Bandinio žymuo } \\
\cline { 2 - 5 } & A5 & A6 & A7 & A8 \\
\hline Ivertinimas & 3 & 5 & 4 & 2 \\
\hline
\end{tabular}

Ivertinus visus kriterijus, nustatyta, kad geriausią paviršiaus morfologiją ( 5 balai) turi A6 bandiniai, kurie apdoroti esant $265 \mathrm{~kW} / \mathrm{cm}^{2}$ energijos tankiui ir kuriems būdingas mažas išsitaškymas, tuštumų dydis ir kiekis.

B eksperimento metu lazeriu buvo apdorotas visas bandinio paviršius, siekiant nustatyti koncentruotos energijos šaltinio ejjimų skaičiaus įtaką bandinio topografijai bei medžiagos mikrolazerinio apdorojimo proceso pobūdžiui.

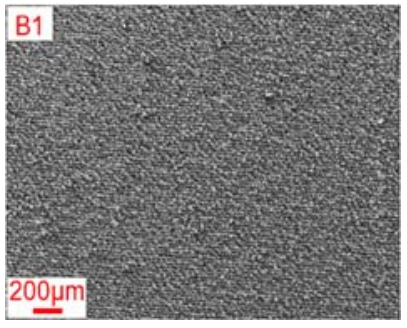

a)

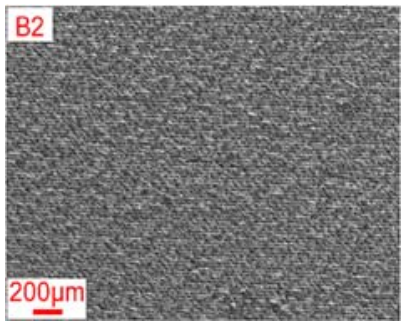

b)

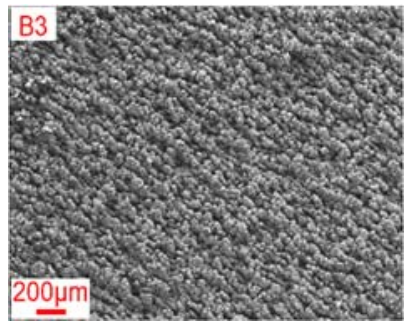

c)

3.3 pav. B eksperimento bandinių paviršiaus topografija: a) B1; b) B2; c) B3

Fig. 3.3. The topography of the surface of specimens in the experiment $B$ :

a) $\mathrm{B} 1$; b) B2; c) B3 
Atliktas bandinių paviršinio sluoksnio apdorojimas, bandiniui suteikiant pastūmą dviem kryptimis, visiškai apdorojant bandinio plotą. Prieš lazerinį apdorojimą bandiniai buvo nušlifuoti iki $R_{a}=0,2 \mu \mathrm{m}$. 3.3 ir 3.4 paveiksluose vaizduojama tipiné topografija esant skirtingam lazerinio mikroapdorojimo ejimų skaičiui.

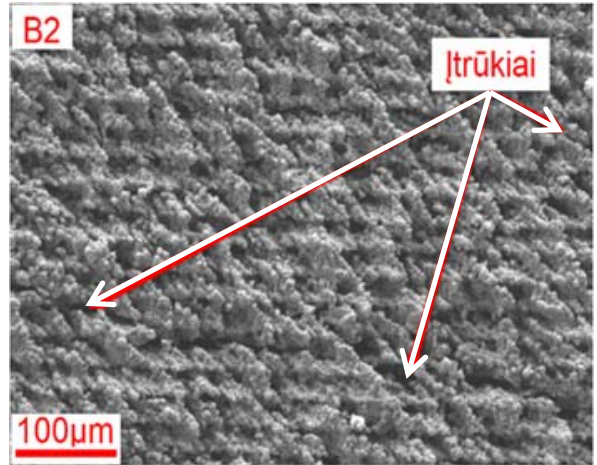

a)

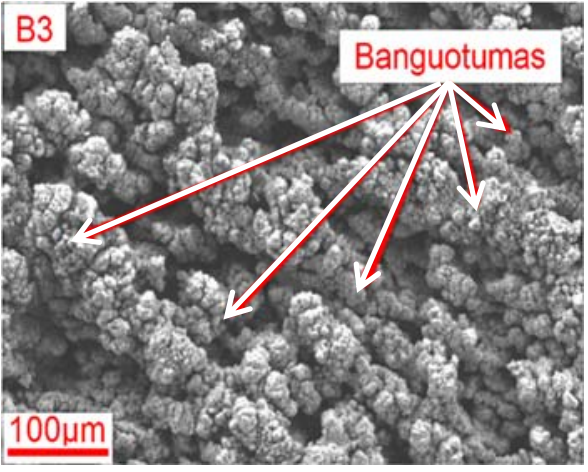

b)

3.4 pav. B eksperimento bandinių lazeriu apdoroto paviršiaus defektai : a) B2; b) B3 Fig. 3.4. Topographics images of the laser processed surface defects of the B experiment samples: a) B2; b) B3

Lazerio spinduliuote visiškai apdorojant sukepintą ir papildomai nušlifuotą paviršių vienu ejjimu, susiformuoja kryptinga, palyginti smulki ir tolygi apdoroto paviršiaus topografija be defektų (3.3 pav., a.). B2 bandinio bendras paviršiaus vaizdas (3.3 pav., b), mažai skiriasi nuo B1, tačiau ejjimų skaičiaus didinimas nuo 1 iki 2 kartų lèmé ịtrūkių atsiradimą B2 bandinyje. Kadangi antras apdorojimo ejjimas atliekamas nespejjus bandiniui ataušti po pirmo ejjimo, įtrūkių atsiradimą lèmè perteklinis paviršiaus perkaitinimas. Ejjimų skaičiu padidinus iki 4 kartų B3 bandinio paviršiuje susiformavo stambesnè (3.3 pav., c)., savita, banguota morfologija, kurią lèmé ypač didelis apdorojimo zonos ịkaitinimas.

Remiantis B1-B3 bandinių morfologijos analize, geriausia apdoroto paviršinio sluoksnio fraktūra pasižymèjo B1 bandinys, apdorotas vienu ejjimu (3.3 pav., a).

Ejjimų skaičiaus didinimas nuo 1 (B1 bandinys) iki 4 (B3 bandinys) neigiamai veikia apdoroto paviršiaus morfologiją - lemia bandinio paviršiaus perkaitinimą ir su juo susijusị ịtrūkių susidarymą bei struktūros grublètumo didejjimą.

C eksperimento metu lazeriu buvo visiškai apdoroti bandinių šoniniai paviršiai, siekiant nustatyti geriausius koncentruotos energijos šaltinių technologinių parametrų derinius. Atliktas bandinių paviršinio sluoksnio apdorojimas, bandiniui suteikiant pastūmą dviem kryptimis, kai apdorojamas visas bandinio plotas. 
Prieš lazerini apdorojimą bandiniai nebuvo nušlifuoti. 3.5 paveiksle matoma ivedamos energijos tankio itaka apdoroto paviršiaus topografijai, apdorojant vienu èjimu.

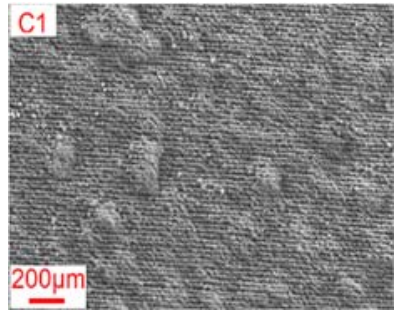

a)

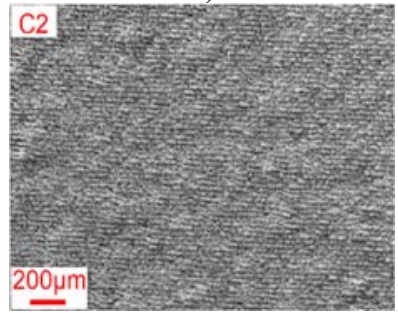

d)

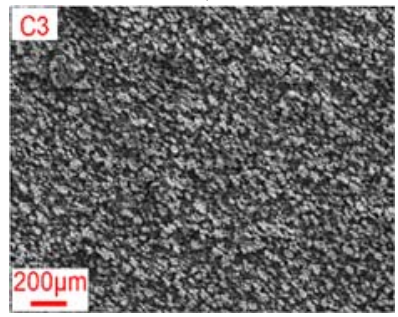

g)

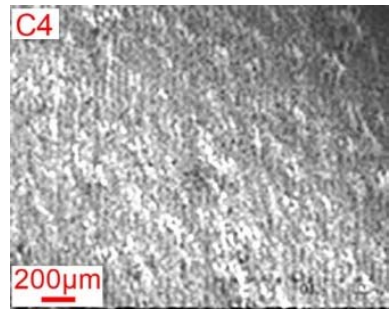

b)

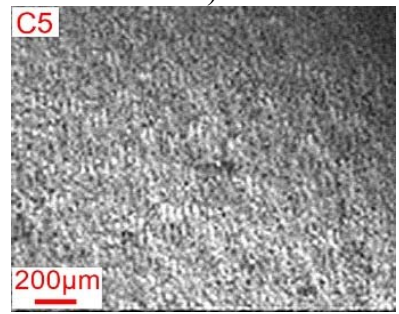

e)

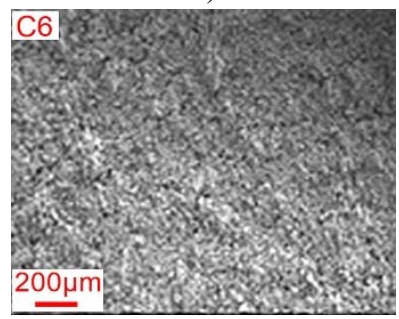

h)

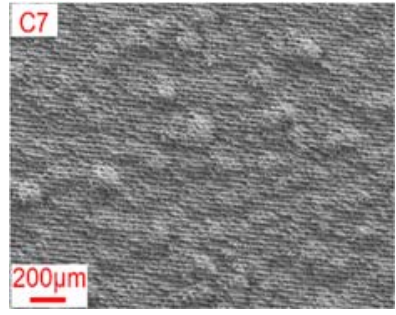

c)

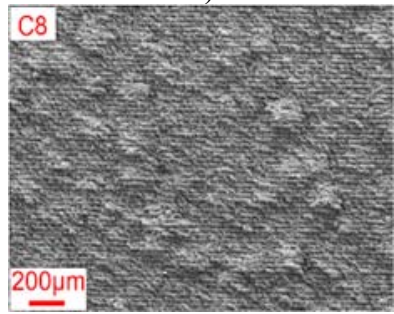

f)

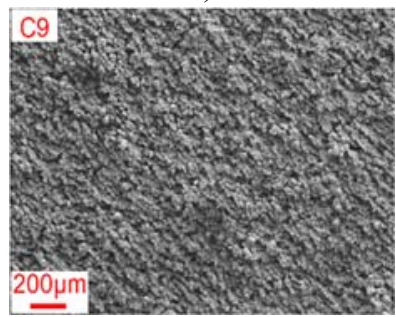

i)

3.5 pav. C eksperimento bandiniu paviršiaus topografija: a) $\mathrm{C} 1$; b) $\mathrm{C} 4$; c) $\mathrm{C}$; d) $\mathrm{C} 2$; e) $\mathrm{C} 5$; f) $\mathrm{C} 8$; g) C3; h) C6; i) C9

Fig. 3.5. Topographics images of the $\mathrm{C}$ experiment samples: a) $\mathrm{C}$; b) $\mathrm{C} 4$; c) $\mathrm{C}$; d) $\mathrm{C} 2$; e) $\mathrm{C} 5$; f) $\mathrm{C} 8$; g) $\mathrm{C} 3$; h) $\mathrm{C} 6$; i) $\mathrm{C} 9$

Remiantis 3.5 paveiksle vaizduojamų bandinių topografijos analize, galima išskirti tris esmines apdoroto paviršiaus faktūras: korètas ir nepakankamai išsilydęs paviršinis sluoksnis ( $\mathrm{C} 3$ ir $\mathrm{C} 9$ bandiniai), netvarkingai išgarintas paviršius su chaotiškai išsiděščiusiais iškilimais $(\mathrm{C} 1, \mathrm{C} 2, \mathrm{C} 7, \mathrm{C} 8$ bandiniai) ir tolygiai bei kryptingai išgarintas paviršius (C4, C5 ir C6 bandiniai). Akivaizdu, kad geriausia paviršiaus topografija susidaro esant $2,5 \mathrm{~W}$ lazerio spindulio pluošto galiai. Siekiant nustatyti lazerinio apdorojimo greičio įtaką, atlikta papildoma C4-C6 bandinių topografijos analizè (3.6 pav., b-d). C4 bandinio paviršiuje matomos 
ryškios rievès (3.6 pav., b)., kurios C5 bandinio atveju nèra taip aiškiai išreikštos (3.6 pav., c). Skirtumą lemia nuo 663 iki $265 \mathrm{~kW} / \mathrm{cm}^{2}$ sumažejęs ịvedamos energijos kiekis. C6 bandinio paviršiuje stebima korèta fraktūra ir banguotumas (3.6 pav., d), kurie atsirado dèl didelio apdorojimo greičio $5 \mathrm{~mm} / \mathrm{s}$ bei nepakankamo energijos kiekio $132 \mathrm{~kW} / \mathrm{cm}^{2}$, dèl kurio sparčiau vyksta terminio poveikio zonos struktūriniai virsmai.

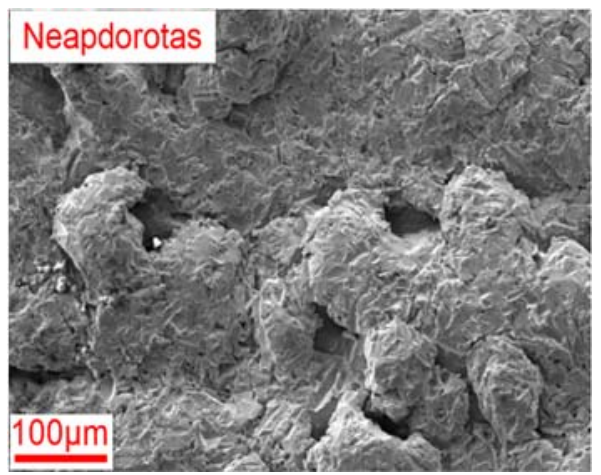

a)

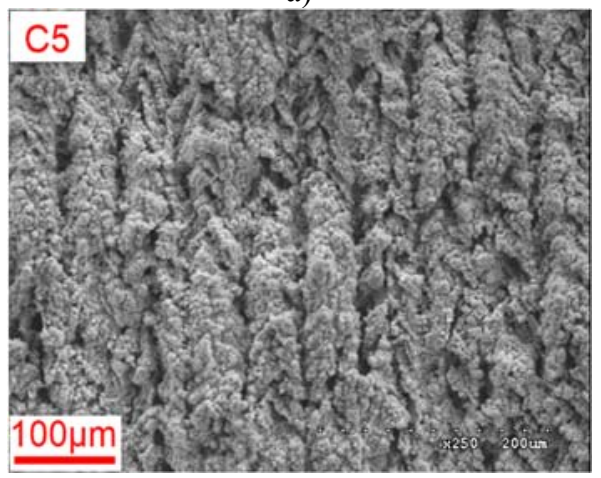

c)

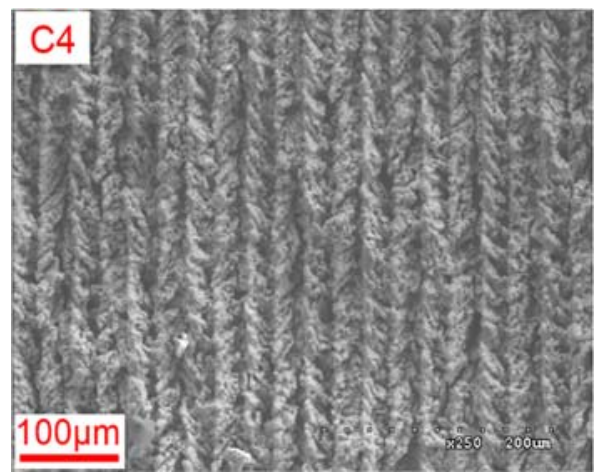

b)

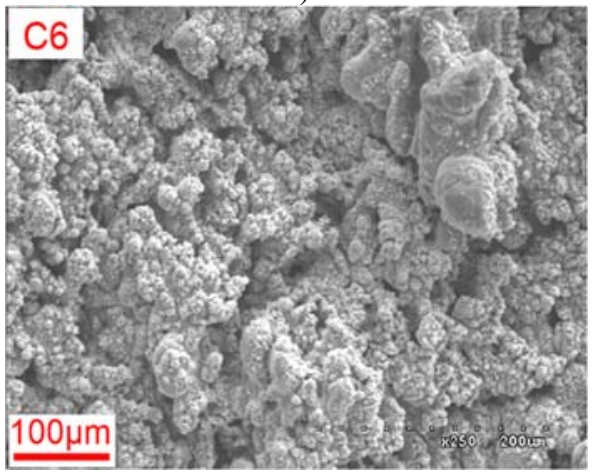

d)

3.6 pav. C eksperimento bandinių paviršių topografija esant skirtingam lazerinio apdorojimo greičiui: a) neapdorotas; b) C4; c) C5; d) C6

Fig. 3.6. Topographics images of the different laser processing speed of the $\mathrm{C}$ experiment samples: a) non processed; b) $\mathrm{C} 4$; c) $\mathrm{C} 5$; d) $\mathrm{C} 6$

3.7 paveiksle matoma lazerinio mikroapdorojimo ėjimų skaičiaus įtaka apdoroto paviršiaus topografijai esant šiems apdorojimo parametrams: $P=2,5 \mathrm{~W}$; $V=2,5 \mathrm{~mm} / \mathrm{s}$. Sukepintą miltelinio pagrindo paviršių apdorojant vienu ejjimu (C5 bandinys), matomas netolygiai išgarintas plonas sukepintas sluoksnis (3.7 pav., a), ėjimų skaičių padidinus iki 2, bandinio paviršiuje matomos kryptingai susiformavusios rèvos, kurios neigiamai veikia paviršiaus profilometrijos 
rodiklius (C10 bandinys). Papildomos energijos ịvedimas, paviršių apdirbant keturiais ejjimais, lemia padidintą sukepinto sluoksnio išgarinimą ( $\mathrm{C} 11$ bandinys) bei vidutinio mikronelygumų aukščio sumažèjimą. Lazerinio apdorojimo ejjimų skaičiu padidinus iki 6, C12 bandinyje stebimi ịtrūkiai. Defektų atsiradimą lemia perteklinis apdorojamo paviršiaus perkaitinimas bei vidiniai įtempiai.

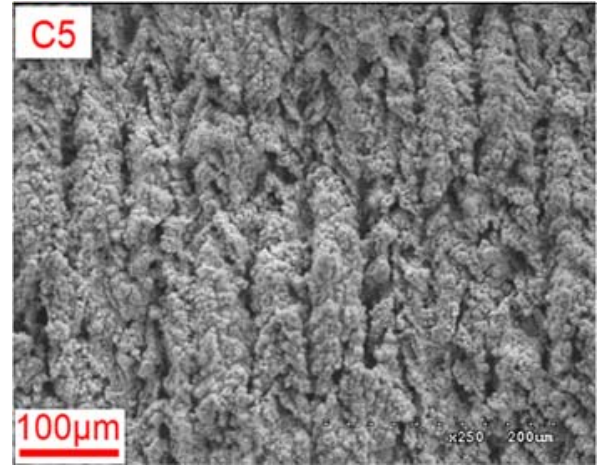

a)

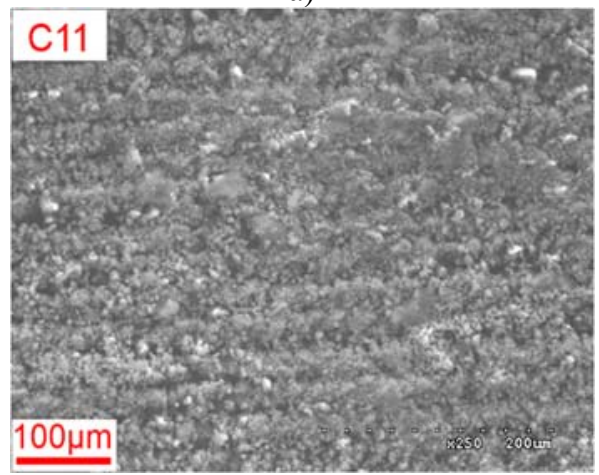

c)

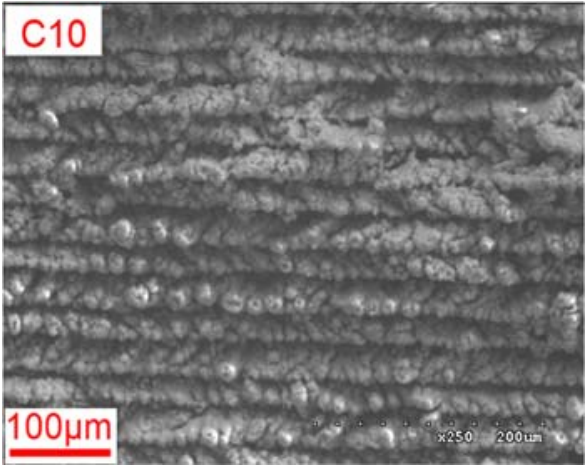

b)

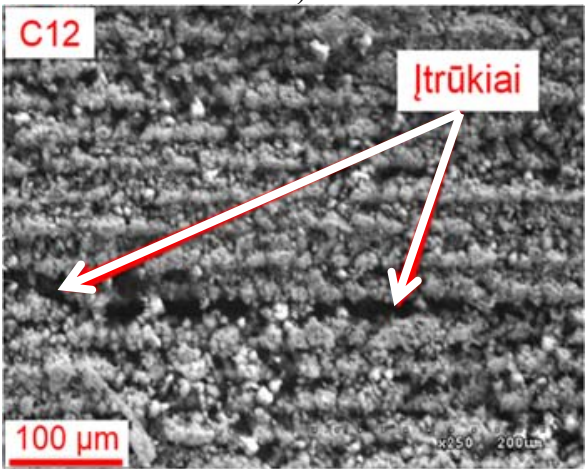

d)

3.7 pav. C eksperimento bandinių paviršių topografija esant skirtingam lazerinio apdorojimo èjimų skaičiui: a) C5; b) C10; c) C11; d) C12

Fig. 3.7. The topography of the surface of samples in the experiment $\mathrm{C}$ at different numbers of laser processing passes: a) C5; b) C10; c) C11; d) $\mathrm{C} 12$

C eksperimento topografijos analizè parodè, kad geriausiu lazerinio garinimo rezultatu pasižymejjimo C11 bandinys, kai $P=2,5 \mathrm{~W}, V=2,5 \mathrm{~mm} / \mathrm{s}$ ir $n=4$.

D eksperimento metu lazeriu buvo visiškai apdoroti bandinių viršutiniai paviršiai, siekiant nustatyti geriausius koncentruotosios energijos šaltinių technologinių parametrų derinius. Atliktas bandinių paviršinio sluoksnio apdorojimas, bandiniui suteikiant pastūmą dviem kryptimis, kai apdirbamas visas bandinio 
plotas. Prieš lazerini apdorojimą bandiniai nebuvo šlifuoti. 3.8 paveiksle matoma ịvedamos energijos įtaka apdoroto paviršiaus topografijai, apdorojant vienu ejjimu.

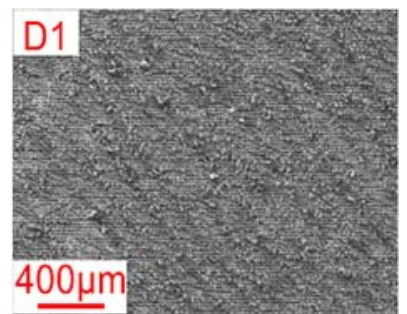

a)

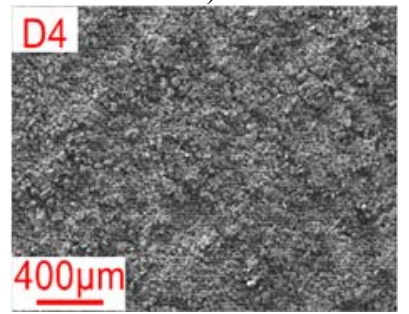

d)

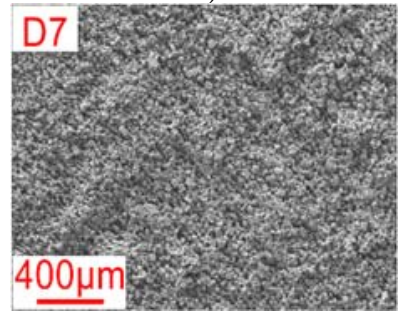

g)

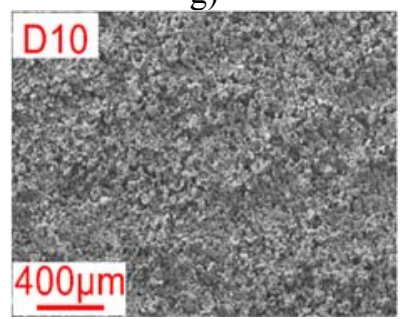

j)

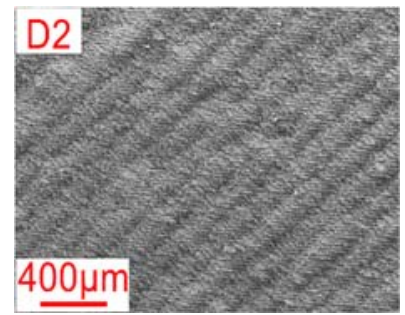

b)

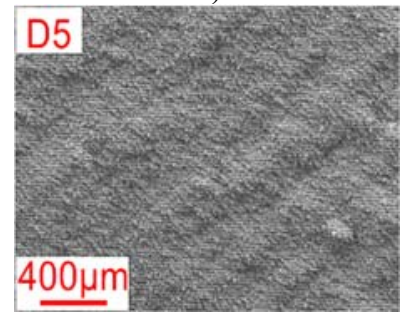

e)

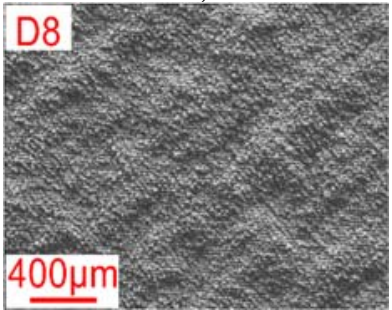

h)

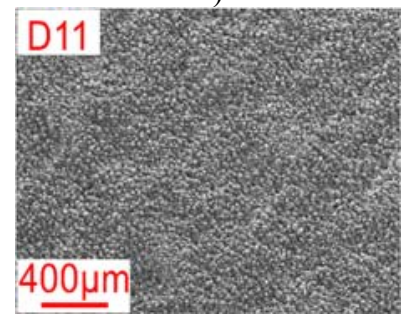

$\mathrm{k})$

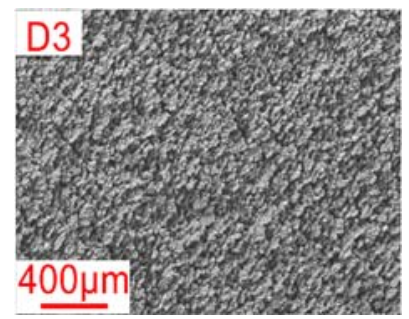

c)

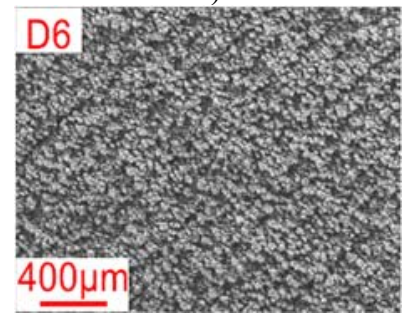

f)

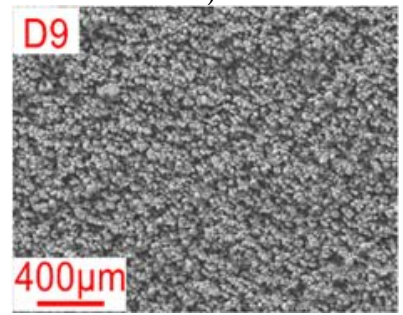

i)

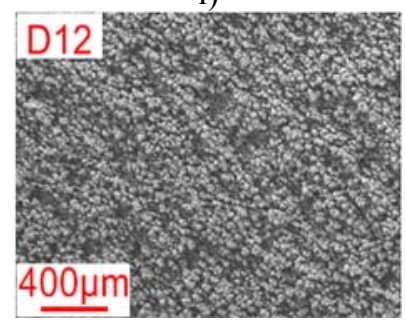

1)

3.8 pav. D eksperimento bandinių paviršių topografija: a) D1; b) D2; c) D3; d) D4; e) D5; f) D6; g) D7; h) D8; i) D9; j) D10; k) D11; 1) D12

Fig. 3.8. The topography of the surface of specimens in the experiment D: a) D1; b) D2; c) D3; d) D4; e) D5; f) D6; g) D7; h) D8; i) D9; j) D10; k) D11;1) D12 
Atliekant topografinę D eksperimento bandinių analizę, galima pastebèti (3.8 pav.), kad bandinių paviršiuje lazerinio apdorojimo metu formuojasi šešios būdingos paviršiaus fraktūros: smulkios rievès (D1 bandinys); koreta banguota fraktūra (D4, D7, D10 bandiniai); stambios rievès (D2 bandinys); banguotumas (D5, D8 bandiniai); smulki korèta fraktūra (D11 bandinys), vidutinè korèta fraktūra (D3, D6, D9, D12 bandiniai). Apdoroto bandinio paviršiuje susiformavusios smulkios bei stambios rievès, korètumas neigiamai veikia paviršiaus profilometrijos rodiklius, todèl išsamesnè bandinių, pasižyminčiu šiais defektais, topografinè analizė neturi prasmès. Lazerinio mikroapdorojimo poveikio apdorotam bandinio paviršiui panašumas matomas nagrinejjant D5 ir D8 bandinių topografinius vaizdus. Tačiau dèl didesnio paviršiaus banguotumo D8 bandinyje geriausiu lazeriniu garinimu pasižymëjo D5 bandinys. Tikètina, kad efektyviausiu lazeriniu apdorojimu pasižymès bandiniai, apdoroti $2,5 \mathrm{~mm} / \mathrm{s}$ greičiu.

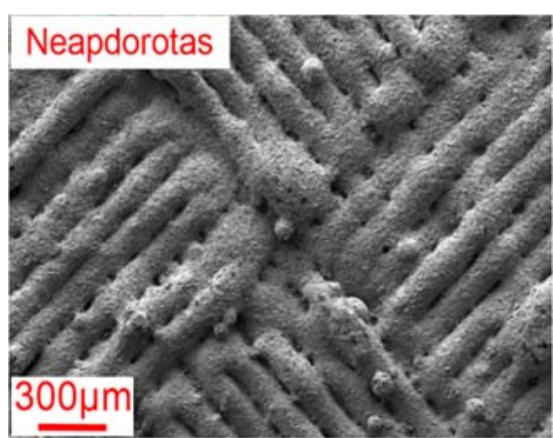

a)

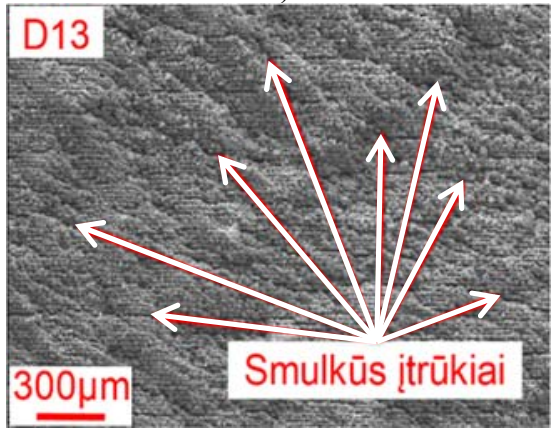

c)

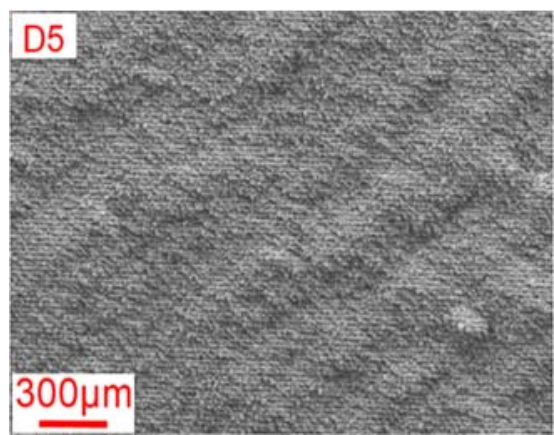

b)

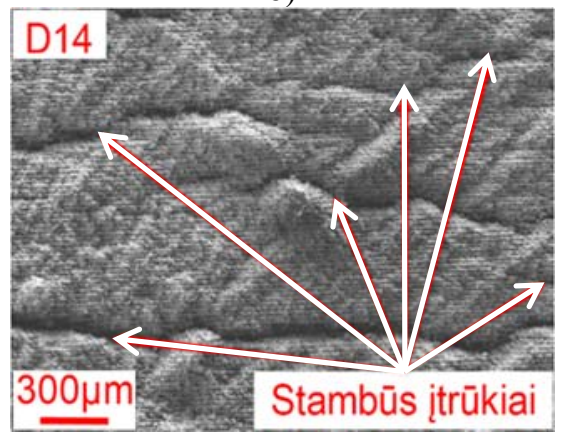

d)

3.9 pav. D eksperimento bandinių paviršių topografija esant skirtingam lazerinio apdorojimo ejjimų skaičiui: a) neapdorotas; b) D5; c) D13; d) D14

Fig. 3.9. The topography of the surface of specimens in the experiment $D$ at different numbers of laser processing passes: a) non processed; b) D5; c) D13; d) D14 
3.9 paveiksle matomas ėjimų skaičiaus poveikis apdoroto paviršiaus topografijai esant šiems apdorojimo parametrams: $\mathrm{P}=2,5 \mathrm{~W} ; \mathrm{V}=2,5 \mathrm{~mm} / \mathrm{s}$. Papildomos energijos ịvedimas, paviršių apdorojant dviem ejjimais, lemia smulkių įtrūkių atsiradimą (D13 bandinys). Ejjimų skaičių padidinus iki 4 (D14 bandinyje), susiformuoja stambūs įtrūkiai. D13 ir D14 bandinių defektų atsiradimo mechanizmas tiesiogiai susijęs su įvedamos šilumos kiekiu bei kristalizacijos virsmais. İtrūkiai apdirbamo ploto paviršiuje nèra leistini, todèl apdirbant viršutinị sukepintą bandinio paviršių, èjimų skaičiaus didinimas yra neracionalus.

\subsection{Profilometrijos analizè}

Darbe nagrinejjami A, B, C ir D eksperimentų bandinių profilometrijos rezultatai. Prieš atliekant lazerinio mikroapdorojimo parametrų įtakos sukepintų bandinių paviršiams analizę, buvo atlikti neapdorotų viršutinio ir šoninio paviršių vidutinio mikronelygumų aukščio matavimai.

Sukepinto, nepdoroto šoninio paviršiaus vidutinis šiurkštumas siekia $R_{a}=$ $9,2 \mu \mathrm{m}$, tuo tarpu viršutinio paviršiaus šiurkštumas $R_{a}=17,9 \mu \mathrm{m}$. Skirtumą lemia technologiniai selektyviojo lazerinio sukepinimo proceso ypatumai. Akivaizdu, kad viršutinio ir šoninio sukepinto paviršiaus lazerinio apdorojimo eiga bei galutinio darbo rezultatas gali būti skirtingi. Todèl tikslinga atlikti abiejųviršutinio ir šoninio-paviršių tyrimą.

Siekiant parinkti optimalius sukepintų bandinių lazerinio mikroapdorojimo parametrus, pirmame tyrimų etape buvo atliktas sukepintų ir nupoliruotų bandinių apdorojimas lazeriu. Buvo atlikta A ir B serijos apdorotų bandinių profilometrijos analizė ir pamatuotos vidutinès bandinių paviršiaus šiurkštumo reikšmès.

Atliekant kokybinę paviršiaus morfologijos analizę, buvo nustatyta, kad esant 2,5 W apdorojimo galiai bei apdorojimo greičiui nuo $1 \mathrm{iki} 7,5 \mathrm{~mm} / \mathrm{s}$ galima tikètis geresnių šiurkščio rezultatų (A5-A8 bandiniai). Šioje serijoje greitis buvo nuosekliai didinamas nuo 1 iki $7,5 \mathrm{~mm} / \mathrm{s}$, išlaikant pastovius kitus parametrus. Gauti šių bandinių šiurkščio matavimo rezultatai leidžia ịvertinti lazerinio apdorojimo greičio poveiki paviršiaus šiurkščiui (3.10 pav.). Toliau yra pateikiami šių bandinių paviršiaus profilometrijos rezultatai.

A eksperimento (A5-A8 bandinių) profilometrijos rezultatai.

A eksperimento profilometrijos rezultatų analizè rodo (3.10 pav.), kad didžiausias apdoroto paviršiaus šiurkštumas $R_{a}=2,2 \mu \mathrm{m}$ (bandinys A5) yra esant $1 \mathrm{~mm} / \mathrm{s}$ apdorojimo grečiui. Tai lemia perteklinis paviršiaus ịkaitinimas (E3 ịvedamos energijos lygmuo) ir besiformuojantys įtrūkiai. Esant $2,5 \mathrm{~mm} / \mathrm{s}$ apdorojimo greičiui (E2 ịvedamos energijos lygmuo), stebimas mažiausias apdoroto paviršiaus šiurkštis $R_{a}=1,27 \mu \mathrm{m}$ (A6 bandinys). Mažą šiurkštumą lemia tai, kad 
apdoroto takelio paviršiuje nėra ịtrūkių bei terminio poveikio zonoje stebimas mažas ištaškymas (3.2 pav., b). Nuoseklus apdorojimo greičio didinimas iki 5 bei $7,5 \mathrm{~mm} / \mathrm{s}$ neigiamai veikia apdoroto paviršiaus profilometriją, vidutinis mikronelygumų aukštis $R_{a}=1,43 \mu \mathrm{m}$ (A7 bandinys) bei atitinkamai $R_{a}=1,83 \mu \mathrm{m}$ (A8 bandinys). Tolygų šiurkštumo didejjimą nuo $R_{a}=1,27 \mu \mathrm{m}$ (A6 bandinys) iki $R_{a}=1,43 \mu \mathrm{m}$ (A7 bandinys) lemia padidèjęs metalo ištaškymas (3.2 pav.) bei stambios tuštumos bandinio paviršiuje, matomos 3.1 paveiksle. Šiurkštumo didejjimą nuo $R_{a}=1,43 \mu \mathrm{m}$ (A7 bandinys) iki $R_{a}=1,83 \mu \mathrm{m}$ (A8 bandinys) lemia susiformavusios rievès apdoroto takelio paviršiuje (3.2 pav.).

A eksperimento tyrimo metu nustatyta, kad A6 bandinys pasižymi mažiausiu šiurkštumu $R_{a}=1,27 \mu \mathrm{m}$ dèl mažo išgarinto tūrio ištaškymo terminio poveikio zonoje (3.2 pav., b) bei mažesnių apdoroto paviršiaus mikronelygumų (3.1 pav., e).

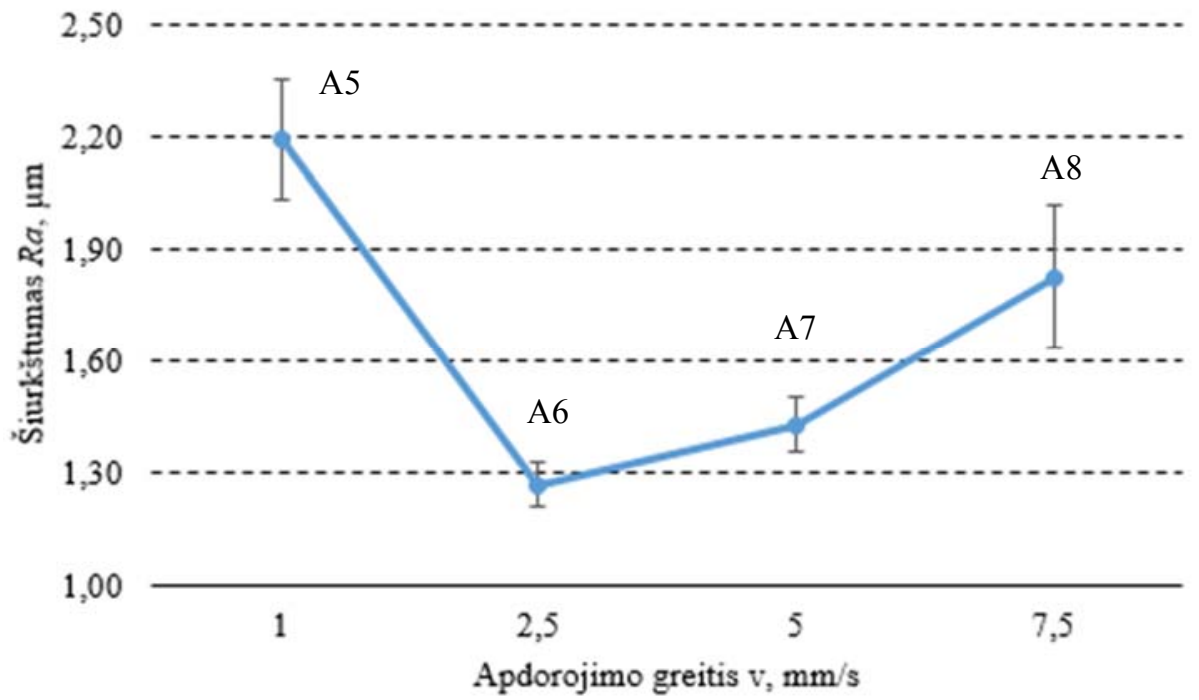

3.10 pav. A eksperimento bandinių šiurkščio priklausomybè nuo lazerinio apdorojimo greičio

Fig. 3.10. The specimens' profilometry dependence on the laser processing speed in the experiment A

B eksperimento (B1-B3 bandinių) profilometrijos rezultatai.

B eksperimento profilometrijos rezultatų analizè parodè (3.11 pav.), kad mažiausią paviršiaus šiurkštumą turi $\mathrm{B} 1$ bandinys, apdorotas vienu èjimu, o $R_{a}$ siekia 3,04 $\mu \mathrm{m}$. Ėjimų skaičių padidinus iki dviejų, vidutinis mikronelygumų aukštis padidèja iki $R_{a}=3,3 \mu \mathrm{m}$ (B2 bandinys), o šiurkštumo padidèjimą lemia paviršiuje besiformuojantys įtrūkiai, kurie yra matomi 3.4 pav., a. Didinant su- 
kepinto bandinio lazerinio mikroapdorojimo ejjimų skaičių iki 4, bandinio paviršiuje atsiranda banguotumas (3.4 pav., b), o šiurkštumas padideja iki $R_{a}=$ $8,05 \mu \mathrm{m}$ (B3 bandinys).

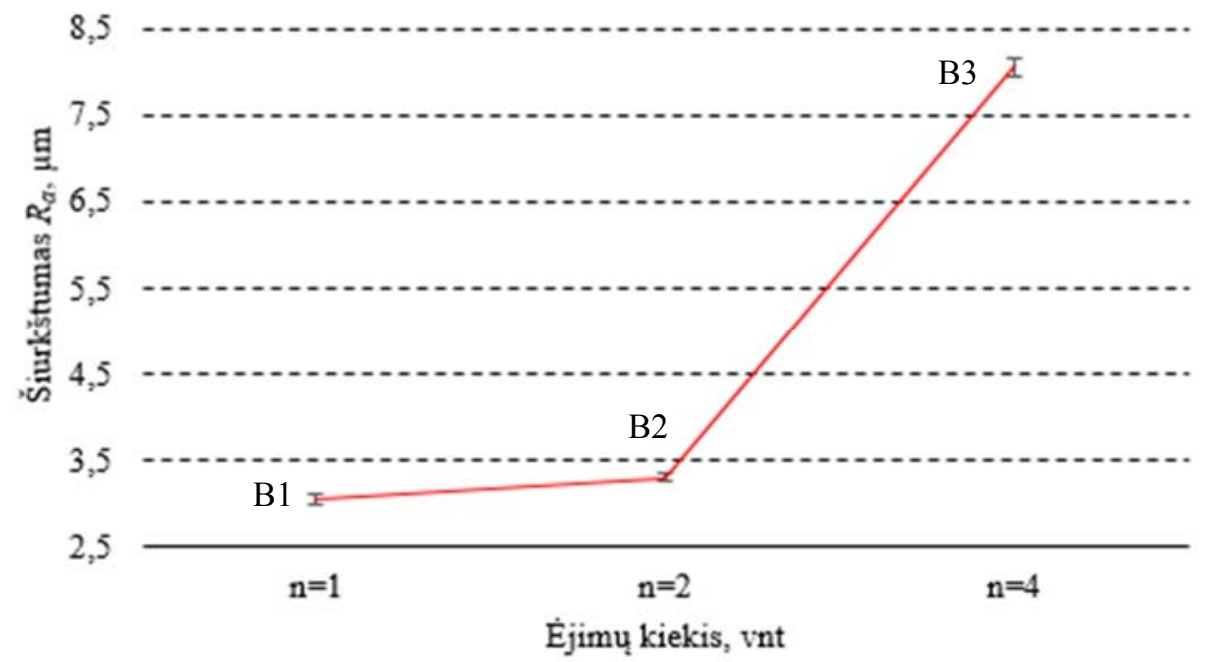

3.11 pav. B eksperimento bandinių šiurkščio priklausomybė nuo lazerinio apdorojimo èjimų skaičiaus

Fig. 3.11. The specimens' profilometry dependence on the number of passes of laser processing in the experiment $\mathrm{B}$

C eksperimento (C1-C12 bandiniu) profilometrijos matavimo rezultatai.

Mikroskopijos tyrimo metu nustatyta, kad Fe-Ni-Co milteliu pagrindu sukepintam ir papildomai neapdorotam šoniniam paviršiui būdingas skirtingos krypties didelis paviršiaus netolygumas (2.3 pav., a). Bandinio paviršiuje formuojasi ryškūs, išgaubti aplydymo sluoksniai, o šoninio paviršiaus šiurkštis siekia $R_{a}=$ $9,2 \mu \mathrm{m}$. Bandinių paviršiaus profilometrijos tyrimais nustatyta, kad esant E2 ivvedamos energijos lygmeniui, kai lazerio spindulio pluošto galia $2,5 \mathrm{~W}$, stebimos mažiausios apdoroto paviršiaus mikronelygumų aukščio reikšmės (3.12 pav.). Esant 2W (E1 ịvedamos energijos lygmuo) bei 3W (E3 ịvedamos energijos lygmuo) lazerio spindulio pluošto apdorojimo galiai stebimas apdoroto paviršiaus vidutinio mikronelygumo aukščio padidejimas lyginant su E2 ivvedamos energijos lygmeniu. Mažiausia $\mathrm{C}$ eksperimento bandinių paviršiaus šiurkštumo reikšmė $R_{a}=5,43 \mu \mathrm{m}$ (C5 bandinys), apdorojant vienu ejjimu, yra pasiekta esant E2 įvedamos energijus lygmeniui, kai apdorojimo galia 2,5 W, o ejjimu skaičius $\mathrm{n}=1$. Esant E2 įvedamos energijos lygmeniui formuojasi palankiausios garinimo bei terminių procesų sąlygos vykdant lazerinį mikroapdorojimą. 
Tyrimų metu nustatyta, kad sukepinto ir neapdoroto šoninio paviršiaus šiurkštis $R_{a}=9,2 \mu \mathrm{m}$ (3.13 pav.). Šoninį sukepintą paviršių apdorojus vienu ejji$\mathrm{mu}$, vidutinis mikronelygumų aukštis sumažèjo apie $50 \%$.

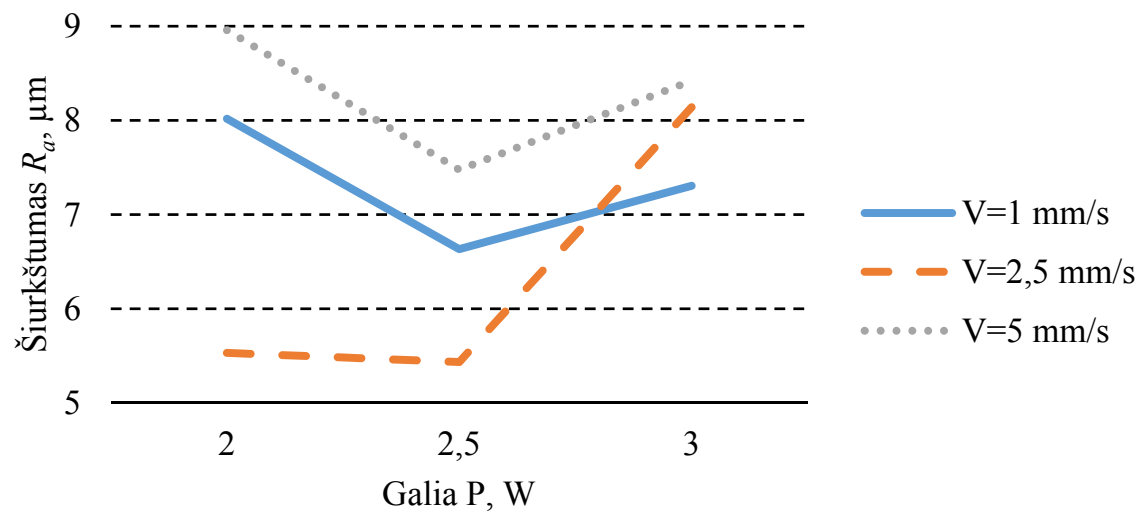

3.12 pav. C eksperimento bandinių šiurkščio priklausomybè nuo lazerinio apdorojimo galios esant skirtingam apdorojimo greičiui

Fig. 3.12. The specimens' profilometry dependence on the power of laser processing at different speeds of the processing in the experiment $\mathrm{C}$

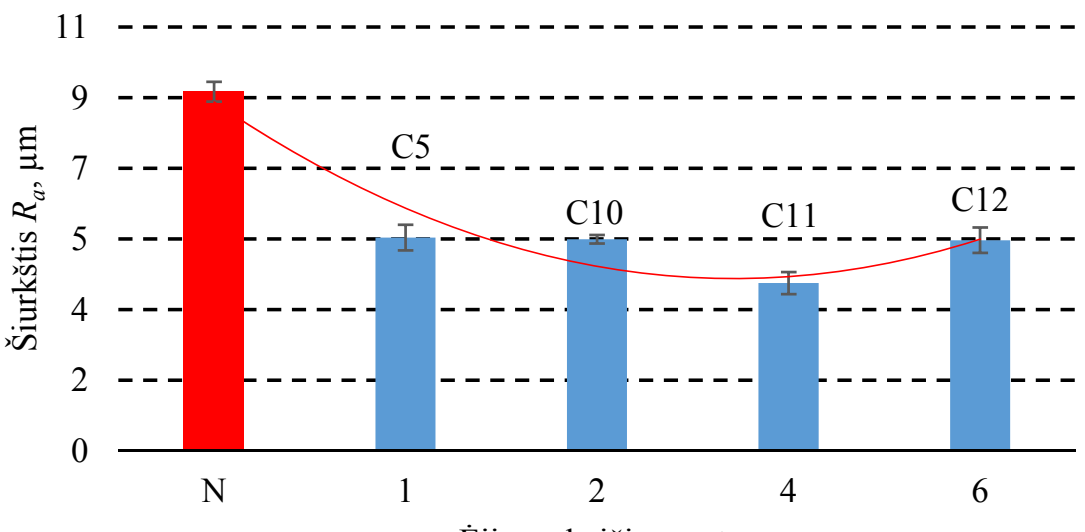

Ėjimų skaičius, vnt.

3.13 pav. C eksperimento bandinių šiurkščio priklausomybė nuo lazerinio apdorojimo èjimų skaičiaus

Fig. 3.13. The specimens' profilometry dependence on the number of passes of laser processing in the experiment $\mathrm{C}$ 
Lazerinio mikroapdorojimo ejjimų skaičiaus didinimas nuo 1 iki 2 neturëjo pastebimo poveikio paviršiaus profilometrijos rodikliams ir vidutine šiurkštumo verte išliko beveik nepakitusi $\left(R_{a}=5,4 \mu \mathrm{m}\right)$.

Ėjimų skaičių padidinus iki 4, stebimas bandinio paviršiaus šiurkštumo sumažejimas iki $R_{a}=4,27 \mu \mathrm{m}$. Šiurkštumo pokytị, kai èjimų skaičius didinamas nuo 1 iki 4, lemia papildomas apdorojamo paviršiaus mikronelygumų viršūnių išgarinimas. Dar labiau padidinus ejjimų skaičių iki 6 (C12 bandinys), bandinio paviršiuje formuojasi įtrūkiai (3.7 pav., d), o vidutinis mikronelygumų aukštis padidejja iki $R_{a}=5,37 \mu \mathrm{m}$. Tai lèmé metalo paviršiaus perkaitinimas bei šiluminių procesų pokytis.

Mažiausia lazeriu apdoroto sukepinto šoninio paviršiaus šiurkštumo vertė $R_{a}=4,27 \mu \mathrm{m}$ (C11 bandinys) buvo pasiekta esant E2 lazerinio apdorojimo ịvedamos energijos lygmeniui, apdirbant keturiais ejjimais.

D eksperimento (D1-D14 bandinių) profilometrijos matavimo rezultatai.

Mikroskopijos tyrimo metu nustatyta, kad Fe-Ni-Co milteliu pagrindu sukepintam ir papildomai neapdorotam viršutiniam paviršiui būdinga dèsningai susiformavusi kryptinga struktūra (2.3 pav., b). Bandinio paviršiuje formuojasi ryškūs išgaubti aplydymo sluoksniai, o paviršiaus šiurkštis siekia $R_{a}=17,9 \mu \mathrm{m}$.

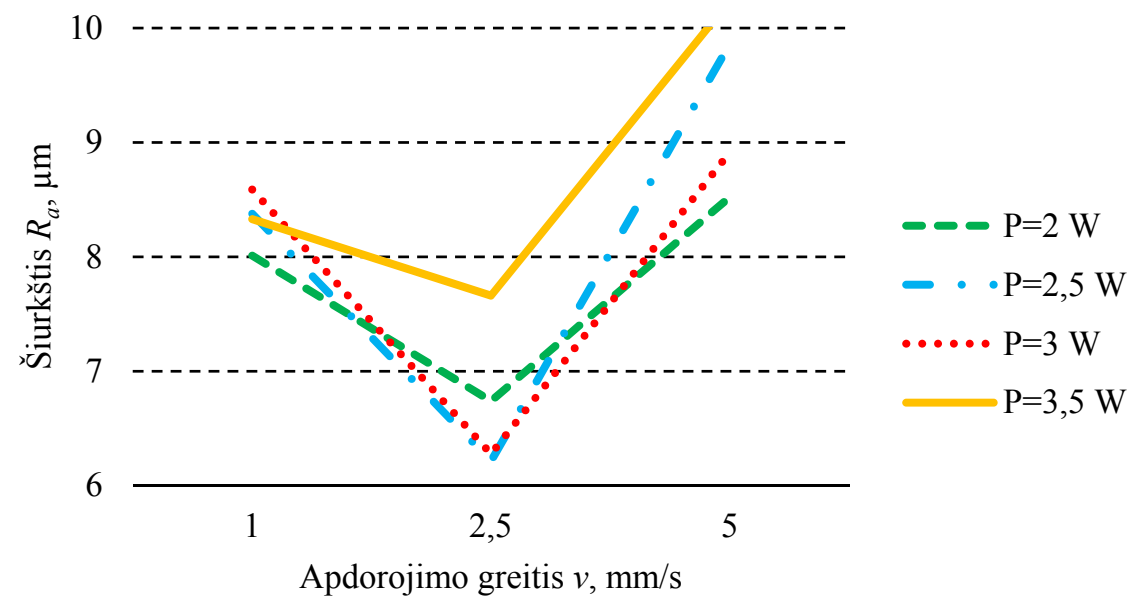

3.14 pav. D eksperimento bandinių šiurkščio priklausomybè nuo lazerinio apdorojimo greičio esant skirtingai apdorojimo galiai

Fig. 3.14. The specimens" profilometry dependence on the laser processing speed at different levels of power of laser processing in the experiment D

Sukepintų ir lazeriu apdorotų bandinių paviršiaus profilometrijos rezultatai parodè, kad lazerinis mikroapdorojimas vienu ejjimu, taikant $2-3,5 \mathrm{~W}$ pluošto 
galią ir $1 \mathrm{~mm} / \mathrm{s}$ apdorojimo greitị (t. y. režimus, atitinkančius E3 ịvedamos energijos lygmeni), leidžia sumažinti paviršiaus šiurkšti daugiau kaip dvigubai, lyginant su sukepintu ir papildomai neapdorotu paviršiumi (3.14 pav.). Padidinus apdorojimo greiti iki $2,5 \mathrm{~mm} / \mathrm{s}$ (E2 ịvedamos energijos lygmuo) paviršiaus šiurkščio parametras $R_{a}$ sumažejo dar labiau, o mažiausia reikšmė $R_{a}=6,22 \mu \mathrm{m}$ nustatyta esant 2,5 W lazerio spindulio pluošto galiai (D5 bandinys). Panašus lazerio apdoroto paviršiaus šiurkštumo rezultatas pasiektas esant $3 \mathrm{~W}$. Toliau padidinus apdorojimo greiti iki $5 \mathrm{~mm} / \mathrm{s}$ ir, atitinkamai, perèjus į E1 ịvedamos energijos lygmens sritị, stebimas ryškus šiurkščio rodiklių padidèjimas.

Tyrimų metu buvo nustatyta, kad esant lazerio spindulio pluošto energijos ir apdorojimo greičio deriniams, užtikrinantiems E2 lazerinio apdorojimo įvedamos energijos lygmeni, susidaro palankiausios bandinio paviršiaus medžiagos garinimo sąlygos ir formuojasi mažiausias paviršiaus šiurkštis.

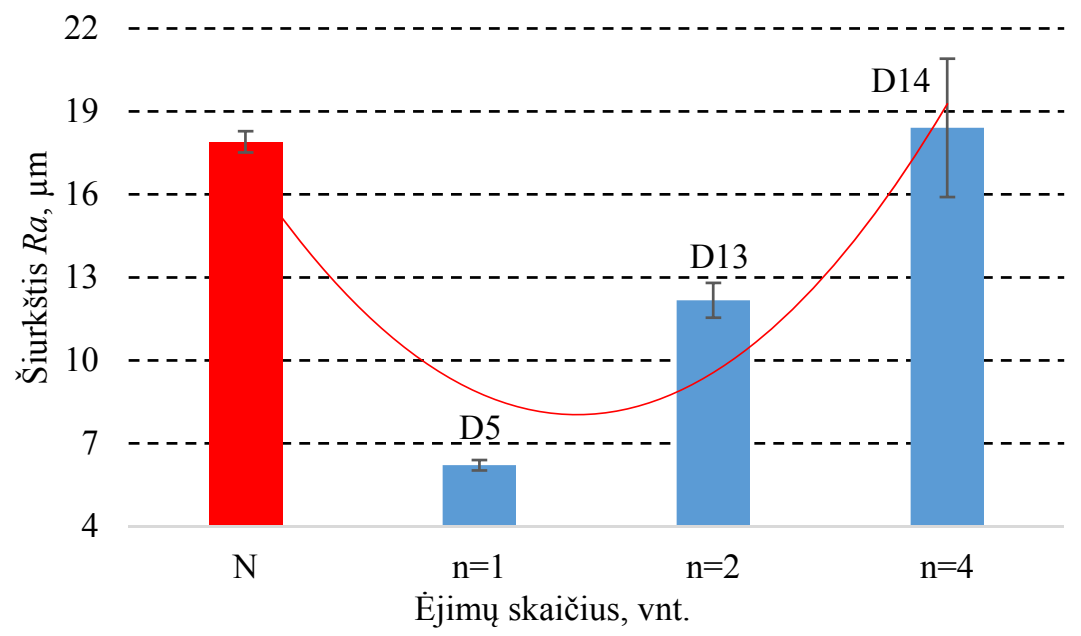

3.15 pav. D eksperimento bandinių šiurkščio priklausomybè nuo lazerinio apdorojimo èjimų skaičiaus

Fig. 3.15. The specimens' profilometry dependence on the the number of passes of laser processing in the experiment $\mathrm{D}$

Tyrimų metu nustatyta, kad sukepinto ir neapdoroto viršutinio paviršiaus šiurkštis $R_{a}=17,9 \mu \mathrm{m}$. Viršutinị sukepintą paviršiu apdorojus vienu ejjimu, esant pluošto galiai $P=2,5 \mathrm{~W}$ ir $2,5 \mathrm{~mm} / \mathrm{s}$ apdorojimo greičiui, vidutinis mikronelygumų aukštis sumažèjo apie 60 \% (D5 bandinys). Ėjimų skaičiaus didinimas iki 2 daro neigiamą įtaką paviršiaus šiurkštumui (3.15 pav.), sukepintų ir lazeriu apdorotų bandinių paviršiaus šiurkštumas padidèja dvigubai nuo $R_{a}=6,22 \mu \mathrm{m}$ 
(D5 bandinys) iki $R_{a}=12,17 \mu \mathrm{m}$ (D13 bandinys). Lazerinio mikroapdorojimo ejjimų skaičiaus didinimas iki 4 kartų, skatina tolesni šiurkštumo didejjimą iki $R_{a}=18,41 \mu \mathrm{m}$ (D14 bandinys). Šiurkštumo rodiklių padidejimą lemia perteklinis apdorojamo paviršiaus kaitinimas ir įtrūkių paviršiuje formavimosi procesas.

D eksperimento lazeriu apdorotų bandinių topografija bei paviršinio sluoksnio mikronelygumų aukštis buvo įvertintas taikant ne tik kontaktinès, bet ir optinès $3 \mathrm{D}$ profilometrijos metodą.

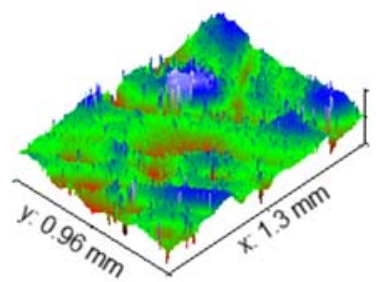

a)

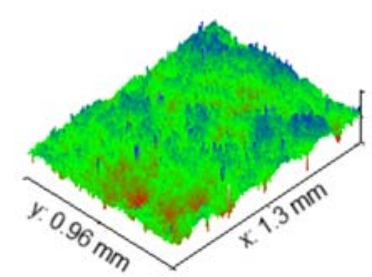

b)

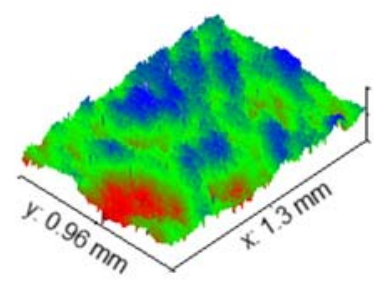

c)

3.16 pav. D eksperimento bandiniu 3D profilometrijos rezultatai:

a) neapdorotas; b) D5; c) D13

Fig. 3.16. 3D profilometry results of the $D$ experiment samples

a) non processed; b) D5; c) D13

3.16 paveiksle pateikti bandinių paviršiaus 3D topografiniai vaizdai iš esmès patvirtino šiurkščio tyrimo rezultatus. Sukepinto ir lazeriu neapdoroto bandinio $(\mathrm{N})$ paviršiuje, kurio paviršiaus topografiją lèmė SLS proceso ypatumai, matomi daugybiniai aukšti iškilimai, paviršius pasižymi išreikštu banguotumu (3.16 pav., a). Mažiausiu šiurkštumo $R_{a}$ parametru pasižymintis D5 bandinio paviršius yra vienalytis. Topografiniame $3 \mathrm{D}$ vaizde jis atrodo lygus, be didelių iškilimų ar įdubimų. Ėjimų skaičiaus didinimas iki 2 lemia pasikartojančių apdoroto paviršiaus iškilimų ir įdubimų atsiradimą (D13 bandinys).

Atliekant tiriamają bandinių paviršiaus profilometrinę analizę nustatyta, kad nepriklausomai nuo konkrečiu pluošto galios ir apdorojimo greičio parametrų reikšmių, jų deriniai, užtikrinantys E2 įvedamos energijos lygmeni, leidžia pasiekti mažiausias apdoroto paviršiaus šiurkštumo reikšmes. Mažiausia D eksperimento šiurkštumo verte $R_{a}=6,22 \mu \mathrm{m}$ pasiekta esant E2 lazerinio mikroapdorojimo ịvedamos energijos lygmeniui, kai apdorojimo galia buvo $P=2,5 \mathrm{~W}$, o lazerinio mikroapdorojimo greitis $v=2,5 \mathrm{~mm} / \mathrm{s}$. Taip pat nustatyta, kad lazerinis mikroapdorojimas daugiau kaip vienu ejjimu yra neracionalus, kadangi, atliekant papildomus apdorojimų ejjimus, paviršius yra perkaitinamas ir pasižymi didesniu šiurkštumu. 


\subsection{Mikrokietumo analizè}

Darbe buvo atlikti C ir D eksperimentų bandinių paviršiaus mikrokietumo tyrimai.

Morfologijos bei profilometrijos rezultatai parodè, kad Fe-Ni-Co milteliu pagrindu sukepinto metalo viršutinis bei šoninis paviršiai pasižymi skirtingu paviršinio sluoksnio reljefu ir skirtingu šiurkščiu. Dèl to koncentruotosios energijos šaltinio pluošto ir sukepintos medžiagos sąveikos vietoje gali vykti skirtingi fizikiniai bei cheminiai procesai. Todèl būtina ištirti abiejų $\mathrm{C}$ ir $\mathrm{D}$ etapų lazeriu apdorotu sukepintų paviršių mikrokietumą.

$\mathrm{C}$ eksperimento ( $\mathrm{C} 1-\mathrm{C} 12$ bandinių) mikrokietumo matavimo rezultatai.

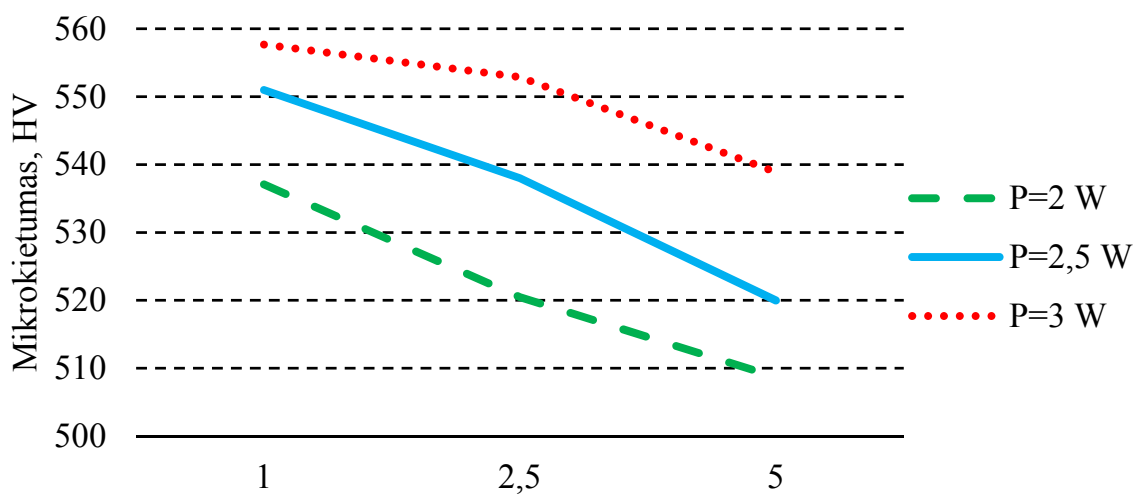

Apdorojimo greitis $v, \mathrm{~mm} / \mathrm{s}$

3.17 pav. C eksperimento bandinių mikrokietumo priklausomybè nuo lazerinio apdorojimo greičio esant skirtingai apdorojimo galiai

Fig. 3.17. The dependence of the microhardness of specimens on laser processing speed at different levels of power in the experiment $\mathrm{C}$

Lazerinio mikroapdorojimo metu spinduliuote paveikto paviršiaus mikrokietumą gali lemti: užgrūdinto sluoksnio gylis, paviršiaus mikrostruktūra, intermetaliniai junginiai ir oksidų koncetracija (Martinez et al. 2017; Martinez et al. 2012; Bouqeut et al. 2016). Tyrimo metu nustatyta, kad užgrūdinto sluoksnio gylis mažesnis negu $35 \mu \mathrm{m}$. Analogiškas užgrūdinto sluoksnio gylio nustatymo būdas, kuris remiasi bandinio skersinio pjūvio mikrokietumo bei struktūros vertinimu, pateiktas (Martinez et al. 2017; Bouqeut et al. 2016).

C eksperimento mikrokietumo tyrimo metu nustatyta (3.17 pav.), kad mažinant lazerinio apdorojimo greitị ir didinant lazerio galią bei esant perejjimui nuo pirmo iki trečio ívedamos energijos lygmens sukepinto ir lazeriu apdoroto sluoksnio mikrokietumas didejja. Didžiausias mikrokietumo rezultato reikšmių 
skirtumas tarp bandinių apdorotu 2-3 W galiomis, yra iki $10 \%$. Lyginant neapdoroto $297 \mathrm{HV}$ ir apdorotų lazeriu bandinių kietį, skirtumas siekia iki 88 \%. Didžiausia lazerinio apdorojimo kietumo reikšme $558 \mathrm{HV}$ (C7 bandinys) pasiekta esant E3 lazerinio apdorojimo įvedamos energijos lygmeniui, kai $P=3,5 \mathrm{~W}, V=$ $1 \mathrm{~mm} / \mathrm{s}$ ir apdirbant vienu ejjimu (3.17 pav.).

Tyrimu metu nustatyta, kad lazerinio mikroapdorojimo èjimų skaičiaus didinimas praktiškai neturèjo poveikio sukepintos medžiagos mikrokietumo rodikliams (3.18 pav.).

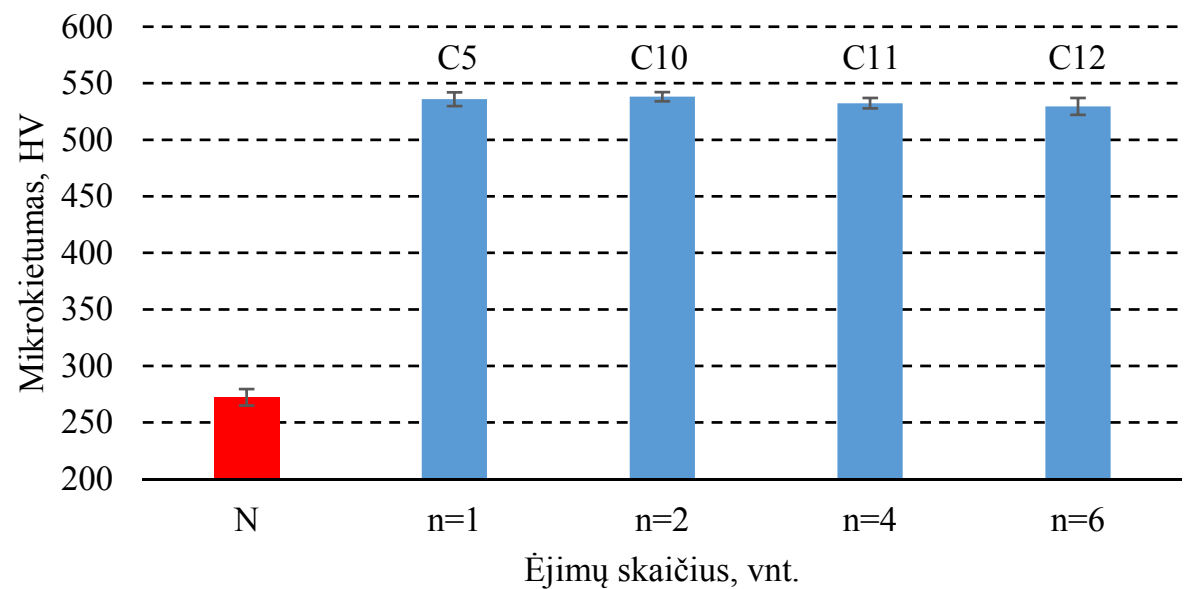

3.18 pav. C eksperimento bandinių mikrokietumo priklausomybė nuo lazerinio apdorojimo ejjimų skaičiaus

Fig. 3.18. The dependence of the microhardness of specimens on laser processing speed at different numbers of laser processing passes in the experiment $\mathrm{D}$

C eksperimento bandinių mikrokietumo analizè parodè, kad apdirbant lazerio spinduliuote sukepintą šoninị paviršių stebima bendra tendencija, kai didžiausios paviršinio sluoksnio metalo mikrokietumo reikšmės pasiektos esant E3 lazerinio apdorojimo įvedamos energijos lygmeniui.

D eksperimento (D1-D14 bandinių) mikrokietumo matavimo rezultatai.

D eksperimento mikrokietumo tyrimo metu nustatyta (3.19 pav.), kad didinant lazerinio apdorojimo ịvedamos energijos kiekị (esant perejjimui nuo pirmo iki trečio ịvedamos energijos lygmens) sukepinto ir lazeriu apdoroto sluoksnio mikrokietumas dideja kaip ir C eksperimento atveju.

Lyginant neapdoroto $297 \mathrm{HV}$ ir apdorotu lazeriu bandinių kietį, skirtumas siekia iki 48 \%. Didžiausia mikrokietumo reikšmè 439 HV (D10 bandinys) pasiekta esant E3 lazerinio apdorojimo ịvedamos energijos lygmeniui, kai $P=$ $3,5 \mathrm{~W}, V=1 \mathrm{~mm} / \mathrm{s}$ ir apdorojant vienu ejjimu (3.19 pav.). Didžiausias mikrokie- 
tumo rezultato reikšmių skirtumas tarp bandinių, apdorotų 2 ir $2,5 \mathrm{~W}$ galiomis siekia, $10,5 \%$, o tarp bandiniu apdorotu, 2,5 ir $3 \mathrm{~W}$ galiomis, siekia $12 \%$. Tolesnis lazerinio apdorojimo galios didinimas neturi teigiamo poveikio sukepinto ir lazeriu apdoroto metalo mikrokietumui, o didžiausias mikrokietumo rezultato reikšmių skirtumas tarp bandinių, apdorotų 3 ir 3,5 W galiomis ir esant tam pačiam apdorojimo greičiui yra tik 1,6 \%. Tai rodo, kad bandinių lazerinio apdorojimo galios didinimas nuo 3 iki $3,5 \mathrm{~W}$ galios neturi žymios įtakos apdoroto metalo mikrostruktūrai, fazinei ir cheminei sudéčiai.

Tyrimų metu nustatyta, kad lazerinio mikroapdorojimo èjimų skaičiaus didinimas neigiamai paveikè lazeriu apdorotų bandinių topografiją bei šiurkštị, todèl nèra prasminga tirti šių bandinių metalo mikrokietumo.

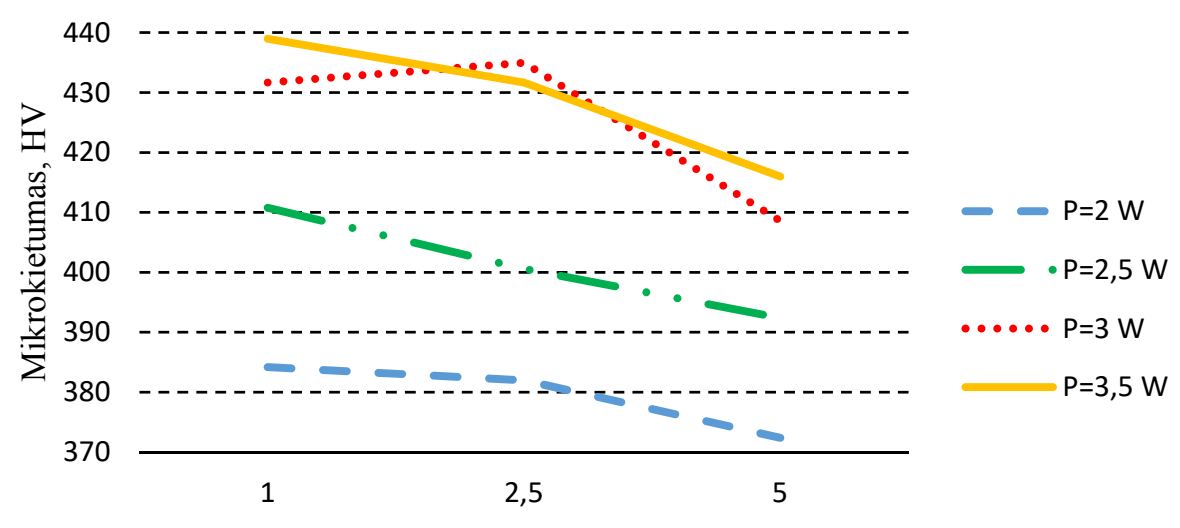

Apdorojimo greitis $v, \mathrm{~mm} / \mathrm{s}$

3.19 pav. D eksperimento bandinių mikrokietumo priklausomybè nuo lazerinio apdorojimo greičio esant skirtingai apdorojimo galiai

Fig. 3.19. The dependence of the microhardness of specimens on laser processing speed in the experiment $\mathrm{D}$ at different levels of power

\subsection{Dilimo analizè}

Darbe nagrinėjamas C ir D eksperimentų serijos bandinių atsparumas dilimui.

Tyrimams naudojama Fe-Ni-Co miltelių pagrindu sukepinta medžiaga dažnai taikoma polimerų liejimo įrangos gamyboje. Eksploatuojant liejimo formas dèl temperatūrinio poveikio paviršinio sluoksnio metalui bei plastiko tekejjimo irangos sukepintu paviršiumi labai svarbios yra eksploatacinès gaminio charakteristikos. Vienas iš pagrindinių rodiklių, nurodančių plastiko liejimo formos 
eksploatacijos laiką, - tai darbinių dalių (paviršių) geometrinių rodiklių stabilumas viso įrangos eksploatacijos metu.

Vienas iš efektyviausių būdų metalinio paviršiaus, dirbančio trinties poroje, eksploatacinèms charakteristikoms patikrinti yra atsparumo dilimui bandymas.

$\mathrm{C}$ eksperimento ( $\mathrm{C} 1-\mathrm{C} 12$ bandinių) atsparumo dilimui tyrimo rezultatai.

Siekiant ịvertinti sukepintų bandinių šoninių paviršių atsparumą dilimui po lazerinio mikroapdorojimo, buvo pasirinkta „pin on plate“ dilimo schema.

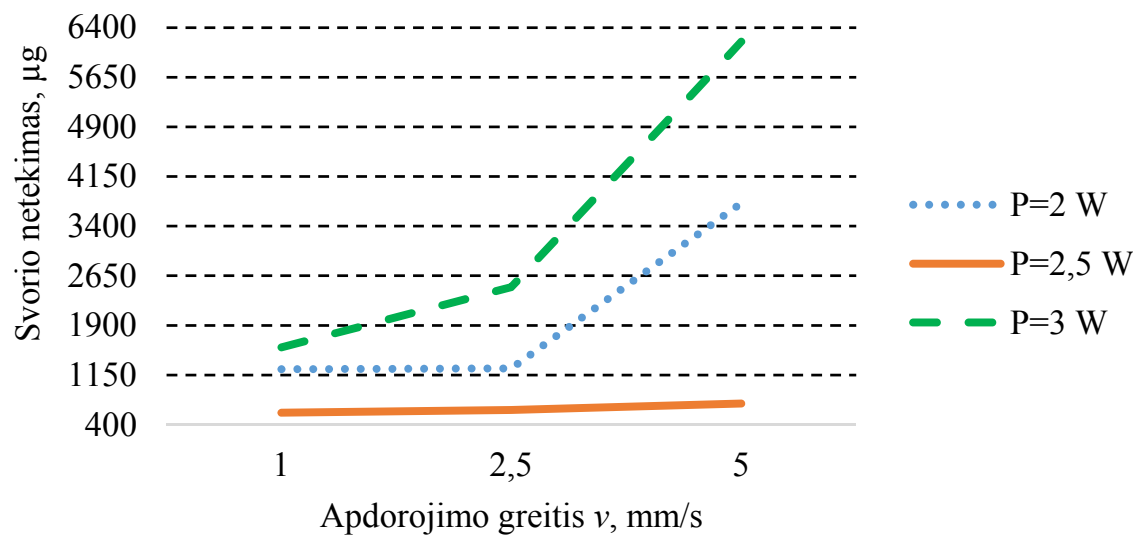

3.20 pav. C eksperimento bandinių svorio netekimo priklausomybė nuo lazerinio apdorojimo greičio esant skirtingai apdorojimo galiai

Fig. 3.20. The dependence of specimen mass loss on laser processing speed in the experiment $\mathrm{C}$ at different levels of power

Tyrimo metu nustatyta, kad neapdoroto šoninio paviršiaus svorio netekimas siekia $2270 \mu \mathrm{g}$. Po lazerinio sukepinto šoninio paviršiaus mikroapdorojimo, kai èjimų skaičius $n=1$ (C5 bandinys), svorio netekimas siekia $620 \mu \mathrm{g}$ (3.21 pav.). Bandinių svorio netekimo skirtumą iki 3,5 karto tarp sukepinto ir sukepinto bei lazerio spinduliuote apdoroto bandinio lemia SLS būdu suformuoto paviršiaus topografijos ypatumai ir paviršinio metalo sluoksnio mechaninių savybių pokyčiai. Lazerinio mikroapdorojimo èjimų skaičiaus didinimas nuo 2 iki 4 lèmé (C10 ir C11 bandinių) svorio netekimo mažèjimą iki 300 ir $180 \mu \mathrm{g}$ atitinkamai. Papildomas sukepinto paviršiaus lazerinis mikroapdorojimas, kai ejjimų skaičius n buvo didinamas nuo 2 iki 4, mažina $\mathrm{C}$ serijos bandinių paviršiaus mikronelygumų reikšmes, o tai teigiamai veikia bandinio svorio netekimo rodiklius. Lazerinio apdorojimo ejjimų skaičiaus didinimas nuo 4 iki 6 lėmé sukepinto paviršiaus perkaitinimą, susiformavo įtrūkiai (3.7 pav., d), del to tiriamųjų bandinių svorio netekimas padidèjo apie $68 \%$ (C12 bandinys). 
Mažiausias bandinio svorio netekimas $180 \mu \mathrm{g}$ (C11 bandinys) buvo pasiektas esant E2 iqvedamos energijos lygmeniui (kai $P=2,5 \mathrm{~W}, V=2,5 \mathrm{~mm} / \mathrm{s}$ ) ir apdirbant keturiais ejjimais (3.21 pav.). Šiuo atveju mažiausią svorio netekimą lèmé mažiausia bandinio $\mathrm{C} 11$ paviršiaus vidutinio mikronelygumų aukščio reikšmė $R_{a}=4,27 \mu \mathrm{m}$.

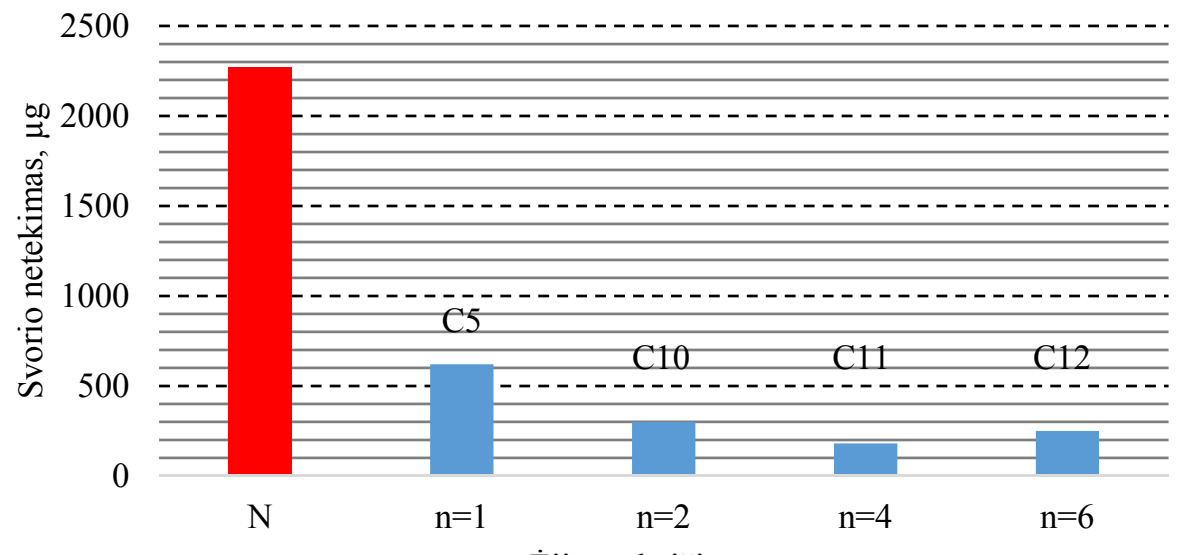

Ėjimų skaičius, vnt

3.21 pav. C eksperimento bandinių svorio netekimo priklausomybė nuo lazerinio apdorojimo èjimų skaičiaus

Fig. 3.21. The dependence of specimen mass loss on number of laser processing passes in the experiment $\mathrm{C}$

Lazerio spinduliuote apdorojant sukepintą šoninị paviršių, pasireiškia bendra tendencija, kai mažiausi bandinio masès nuostoliai stebimi esant E3 lazerinio apdorojimo ịvedamos energijos lygmeniui (3.20 pav.).

Tai lèmé didejjantis įvedamos šilumos kiekis, apdorojimo greičiui mažèjant nuo $5 \mathrm{iki} 1 \mathrm{~mm} / \mathrm{s}$ ir didžiausias metalo paviršiaus mikrokietumas.

C eksperimento bandinių atsparumo dilimui tyrimo metu nustatyta, kad lazerinio apdorojimo ejimų skaičiaus didinimas iki 6 didina bandinių svorio praradimą iki $250 \mu \mathrm{g}$ (C12 bandinys), čia dèl padidejusio šilumos ịvedimo, bandinio paviršiuje formuojasi įtrūkiai (3.7 pav., d), kurie neigiamai veikia masès nuostolių rodiklius.

Siekiant nustatyti lazerinio mikroapdorojimo èjimų skaičiaus įtaką apdoroto paviršiaus eksploatacinèms charakteristikoms, buvo atliktas bandinių trinties koeficiento verčiu palyginimas. Tyrimo metu nustatyta, kad neapdoroto šoninio paviršiaus aritmetinè trinties koeficiento vidurkio reikšmė siekia 0,94 . Po lazerinio sukepinto šoninio paviršiaus mikroapdorojimo (esant $P=2,5 \mathrm{~W}, V=$ 
$2,5 \mathrm{~mm} / \mathrm{s}$ ), neviršijant 2 ejjimų slenksčio (C5 ir C10 bandiniai), trinties koeficiento reikšmé siekia 0,46 ir 0,54 atitinkamai (3.22 pav.). Skirtumą tarp sukepinto ir lazerio spinduliuote apdoroto paviršiaus lèmé SLS būdu sukepinto paviršiaus topografijos ypatumai bei galimai susiformavę tarpmetaliniai junginiai paviršiniame apdoroto bandinio sluoksnyje. Tuo tarpu labai mažas trinties koeficiento skirtumas tarp paviršių apdorotų, 1 ir 2 ejjimais, pasižymi tiesiogine koreliacija su $\mathrm{C}$ serijos lazeriu apdorotų bandinių mikrokietumo pasiskirstymo tendencijomis (3.18 pav.). Didinant lazerinio apdorojimo ejjimų skaičių iki 4 pasiekta mažiausia aritmetinè trinties koeficiento vidurkio reikšmė 0,35 (C11 bandinys). Tai lèmè mažiausias C11 bandinio lazeriu apdoroto paviršiaus šiurkštis (3.13 pav.).

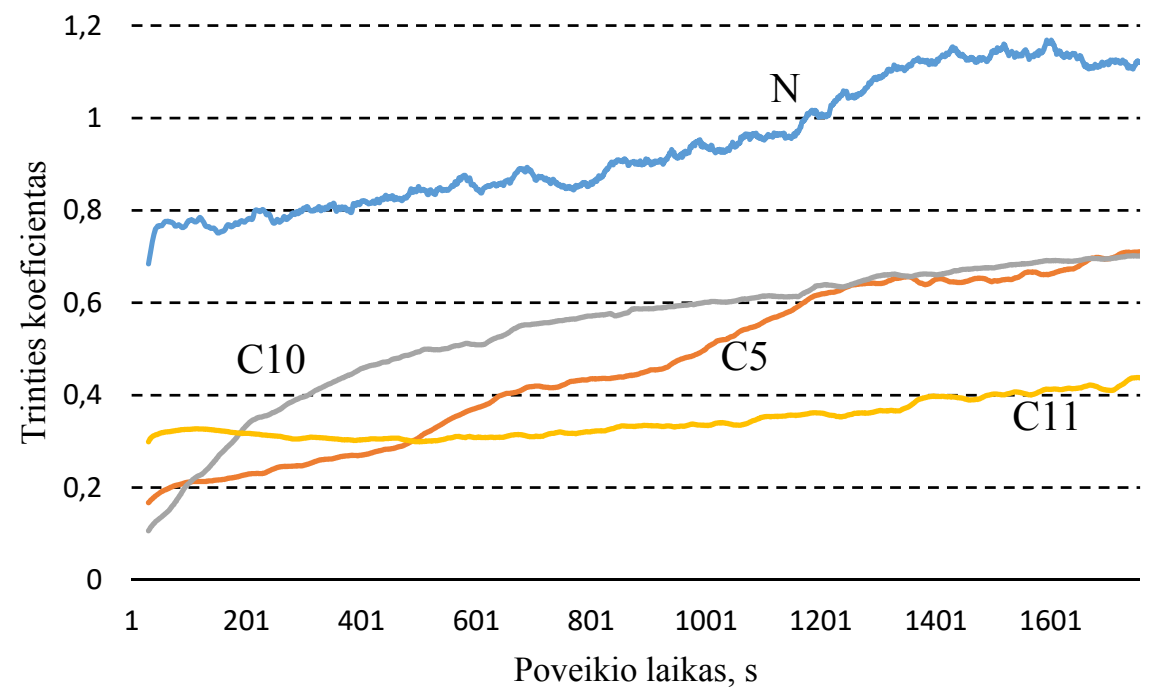

3.22 pav. C eksperimento bandinių tribologinių tyrimų rezultatai

Fig. 3.22. The results of tribological tests of specimens in the experiment $\mathrm{C}$

D eksperimento (D1-D14 bandinių) atsparumo dilimui tyrimo rezultatai.

Siekiant ịvertinti sukepintų bandinių viršutinių paviršių atsparumą dilimui po lazerinio mikroapdorojimo buvo pasirinkta „ball on plate“ dilimo schema. Dilimo bandymo rezultatai parode (3.23 pav.), kad esant lazerio apdorojimo galiai nuo 2 iki 3,5 W ir apdorojimo greičiui $V=1 \mathrm{~mm} / \mathrm{s}$, lazeriu apdoroto paviršiaus svorio netekimas siekia nuo 1730 iki $3240 \mu \mathrm{g}$ (D1-D4 bandiniai). Lazerinio mikroapdorojimo greičio didinimas iki $2,5 \mathrm{~mm} / \mathrm{s}$ (E2 ịvedamos energijos lygmuo) užtikrino mažiausią lazeriu apdoroto paviršiaus svorio netekimą, kuris siekia nuo 540 iki $1570 \mu \mathrm{g}$ (D5-D8 bandiniai). Tai lèmé mažesnis bandinių, apdorotų $2,5 \mathrm{~mm} / \mathrm{s}$ greičiu, paviršiaus mikronelygumų aukštis (3.14 pav.). To- 
lesnis lazerinio mikroapdorojimo greičio didinimas iki $v=5 \mathrm{~mm} / \mathrm{s}$ padidino D serijos bandinių svorio netekimą, kuris siekia nuo 1860 iki $3930 \mu \mathrm{g}$ (D9-D12 bandiniai). Didžiausią svorio netekimą bandinių, apdorotų $5 \mathrm{~mm} / \mathrm{s}$ greičiu (E1 įvedamos energijos lygmuo), lèmè mažiausias bandinių D3, D6, D9 ir D12 mikrokietumas ir jų didžiausias šiurkštis (3.19 pav.).

Lazeriu apdorotų D serijos bandinių svorio netekimas tiesiogiai koreliuoja su jų paviršiaus profilometrijos tyrimų rezultatais (3.14 pav.).

Apdorojant lazerio spinduliuote sukepintą viršutini paviršių, mažiausias bandinio svorio netekimas $540 \mu \mathrm{g}$ (D5 bandinys) stebimas esant E2 iqvedamos energijos lygmeniui, kai $P=2,5 \mathrm{~W} ; v=2,5 \mathrm{~mm} / \mathrm{s}$ (3.23 pav.).

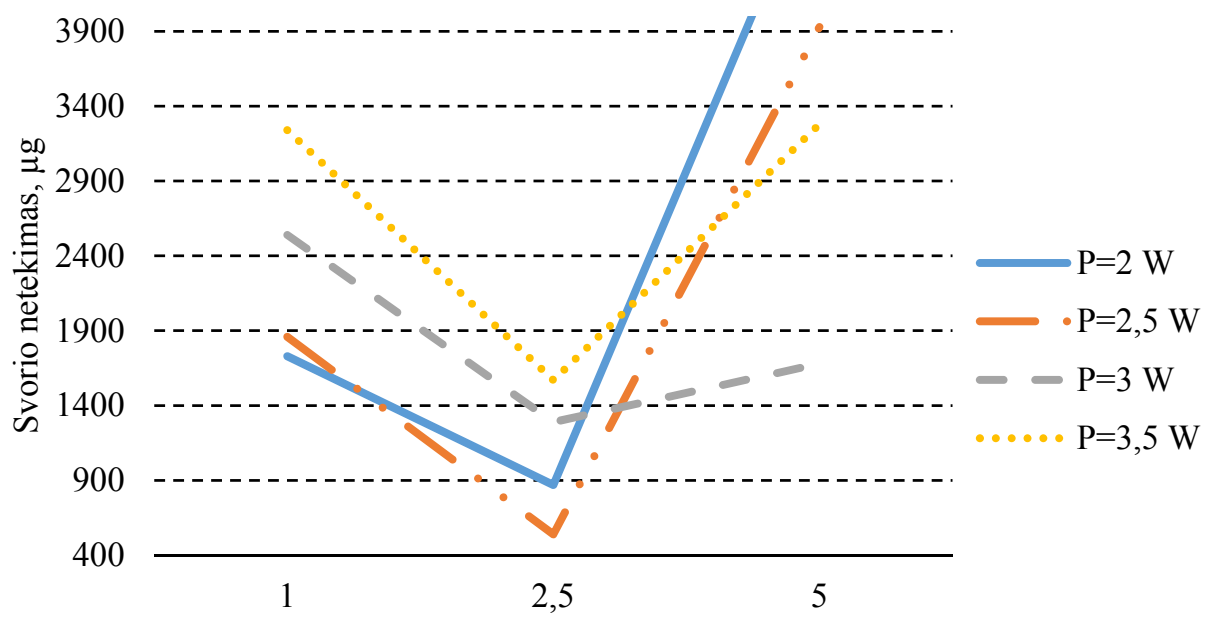

Apdorojimo greitis $v, \mathrm{~mm} / \mathrm{s}$

3.23 pav. D eksperimento bandinių svorio netekimo priklausomybė nuo lazerinio apdorojimo greičio esant skirtingai apdorojimo galiai

Fig. 3.23. The dependence of specimen mass loss on laser processing speed in the experiment $\mathrm{D}$ at different levels of power

Sukepinto ir lazeriu apdoroto viršutinio paviršiaus atsparumas dilimui taip pat buvo ịvertintas pagal indentoriaus, naudoto dilimo bandymo metu, išdilimo pėdsako plotị. Skaitinès analizès vertès pateiktos 3.2 lentelèje.

D eksperimento atsparumo dilimui bandymo analizé parodè (3.2 lentelè), kad mažiausias indentoriaus išdilusio takelio plotas stebimas esant E1 lazerinio apdorojimo įvedamos energijos lygmeniui (D3, D6, D9 bandiniai), kai lazerinio apdorojimo greitis $v=5 \mathrm{~mm} / \mathrm{s}$. 
3.2 lentelè. D eksperimento indentorių dilimo vertinimo rezultatai

Table 3.2. Wear results of the $\mathrm{D}$ experiment indentors

\begin{tabular}{|c|c|c|}
\hline $\begin{array}{c}\text { Bandinio } \\
\text { żymuo }\end{array}$ & $\begin{array}{c}\text { Indentoriaus išdilimo plotis, } \\
\text { mm }\end{array}$ & $\begin{array}{c}\text { Ivedamos energijos } \\
\text { lygmuo }\end{array}$ \\
\hline D1 & $\mathbf{3 , 2 2}$ & E3 \\
\hline D2 & 3,15 & E2 \\
\hline D3 & 2,44 & E1 \\
\hline D4 & $\mathbf{3 , 4 3}$ & E3 \\
\hline D5 & 3,19 & E2 \\
\hline D6 & 3,19 & E1 \\
\hline D7 & $\mathbf{3 , 7 0}$ & E3 \\
\hline D8 & 3,59 & E2 \\
\hline D9 & 3,33 & E1 \\
\hline D10 & $\mathbf{3 , 8 5}$ & E3 \\
\hline D11 & 3,32 & E2 \\
\hline D12 & 3,27 & E1 \\
\hline Neapdorotas & 3,53 & \\
\hline
\end{tabular}

Indentoriaus išdilusio takelio plotis parodo lazeriu apdoroto bandinio paviršiaus atsparumą dilimui. Kuo mažesnis indentoriaus išdilusio pėdsako dydis, tuo tiriamasis paviršius mažiau atsparus trinčiai. Esant E2 įvedamos energijos lygmeniui (D2, D5, D8 bandiniai), stebimas vidutinis indentoriaus išdilusio takelio plotis, kai lazerinio mikroapdorojimo greitis $v=2,5 \mathrm{~mm} / \mathrm{s}$. Didžiausias indentoriaus išdilimas (D1, D4, D7 bandiniai) stebimas esant E3 įvedamos energijos lygmeniui, kai $v=5 \mathrm{~mm} / \mathrm{s}$.

Atliekant indentoriaus atsparumo dilimui tyrimą (3.24 pav.), stebima tiesioginè koreliacija tarp bandinio mikrokietumo ir indentoriaus išdilusio pločio dydžio. Didejant sukepinto ir apdoroto bandinio mikrokietumui, atitinkamai didejja išdilęs indentoriaus plotis.

Analizuojant topografinius indentoriaus išdilusio ploto vaizdus (3.25 pav., a), stebimas didelis D eksperimento neapdoroto bandinio atveju indentoriaus ovališkumas bei prikepusios sankaupos ploto pakraščiuose. Sankaupos rodo, kad dilimo procesas neapdoroto bandinio atveju yra intensyvesnis, lyginant su apdorotu badiniu (3.25 pav., b).

Atsparumas dilimui taip pat buvo įvertintas pagal topografinius bandinių išdilusio ploto vaizdus. 3.26 paveiksle matoma, kad neapdoroto bandinio išdilusio takelio plotis yra didesnis nei apdoroto D5 bandinio. 


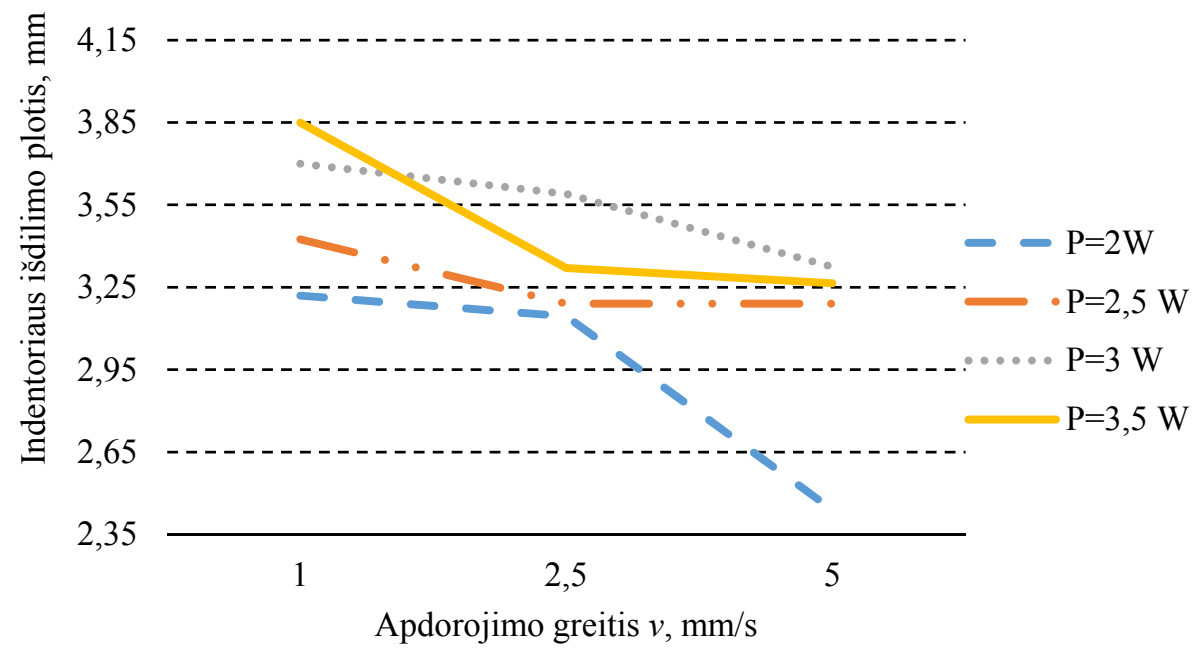

3.24 pav. D eksperimento indentoriaus išdilimo pločio priklausomybė nuo lazerinio apdorojimo greičio esant skirtingai apdorojimo galiai

Fig. 3.24. The dependence of indentors's wear width on laser processing speed in the experiment $\mathrm{D}$ at different levels of power

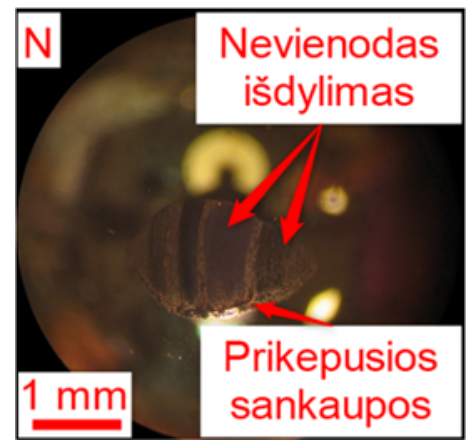

a)

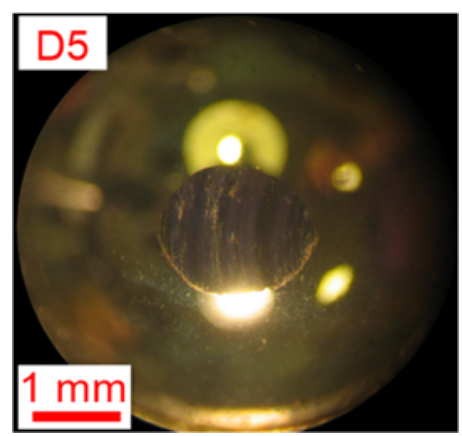

b)

3.25 pav. D eksperimento indentoriaus išdilimo tyrimų rezultatai:

a) neapdorotas; b) D5

Fig. 3.25. Wear results of the D experiment indentors: a) non machined; b) D5

Dilimo bandymo metu nustatyta, kad bandinio dilimo paveikto ploto dydis bei išdilimo intensyvumas D5 bandinio atveju taip pat yra akivaizdžiai mažesni. Skirtumą lèmė 2,9 karto didesnis neapdoroto bandinio paviršiaus šiurkštis bei atitinkamai 1,4 karto mažesnis mikrokietumas. 


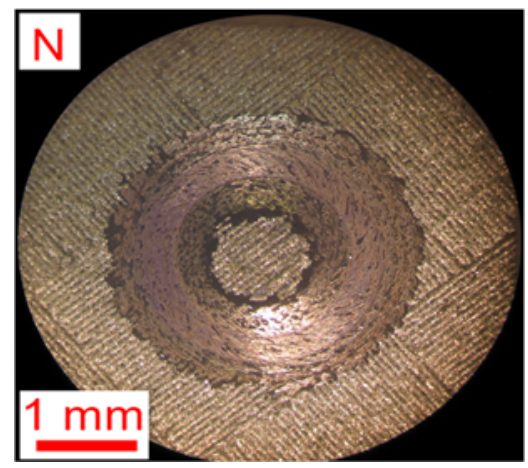

a)

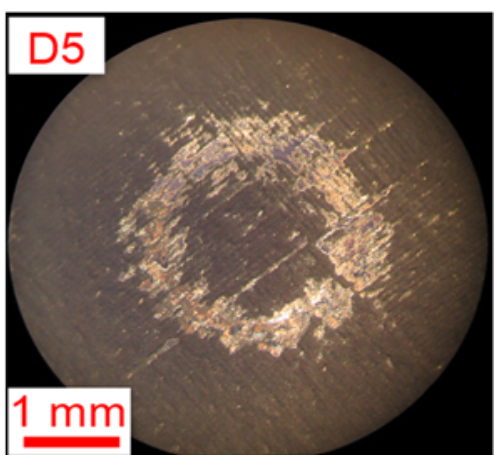

b)

3.26 pav. D eksperimento bandinių išdylimo tyrimų rezultatai:

a) neapdorotas; b) D5

Fig. 3.26. Wear results of the D experiment samples: a) non processed; b) D5

Siekiant nustatyti D eksperimento lazerinio mikroapdorojimo įtaką apdoroto paviršiaus eksploatacinėms charakteristikoms, buvo atliktas trinties koeficiento verčių palyginimas (3.27 pav.).

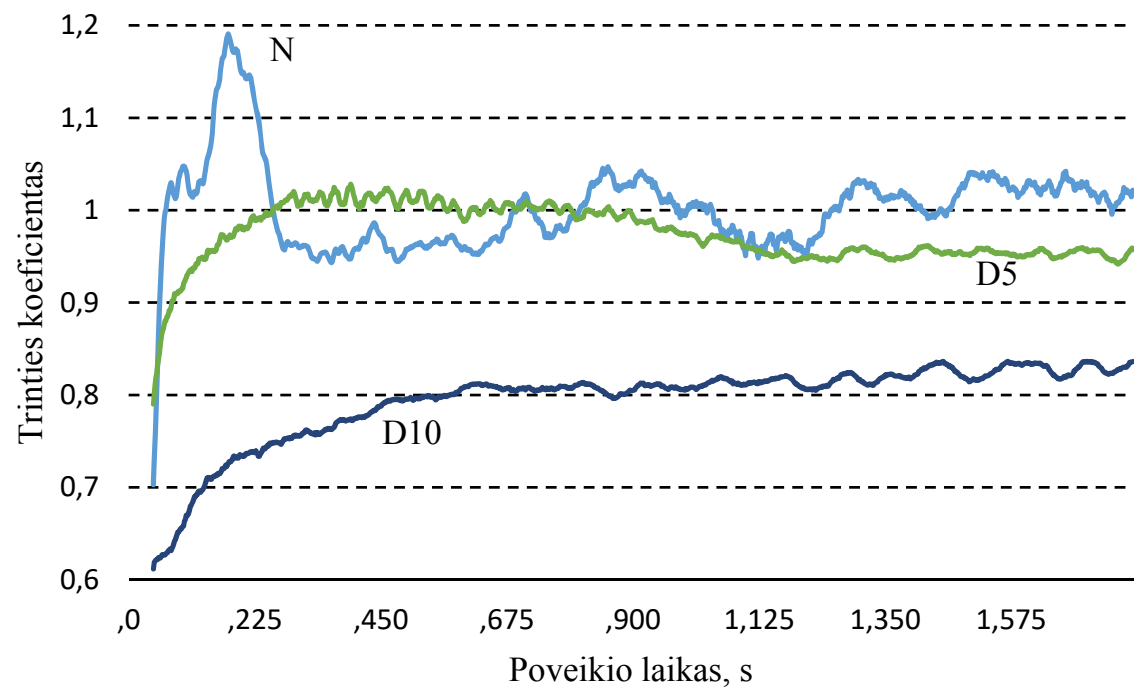

3.27 pav. D eksperimento bandinių tribologinių tyrimų rezultatai Fig. 3.27. Wear results of the $D$ experiment samples 
Tyrimo metu nustatyta, kad neapdoroto viršutinio paviršiaus aritmetinė trinties koeficiento vidurkio reikšmè siekia 1,05 . Tai lèmé ypač didelis neapdoroto viršutinio paviršiaus šiurkštis $R_{a}=17,9 \mu \mathrm{m}$. Po lazerinio sukepinto viršutinio paviršiaus mikroapdorojimo vienu ejjimu, esant $P=2,5 \mathrm{~W}$ ir $V=2,5 \mathrm{~mm} / \mathrm{s}$ (D5 bandinys), trinties koeficiento reikšmé siekia 0,95 . Skirtumą tarp sukepinto ir lazerio spinduliuote apdoroto paviršiaus lèmé SLS būdu sukepinto paviršiaus topografijos ypatumai, didesnis mikrokietumas bei mažas lazeriu apdoroto paviršiaus šiurkštis $R_{a}=6,22 \mu \mathrm{m}$ (D5 bandinys). Mažiausia aritmetinè trinties koeficiento vidurkio reikšmé 0,81 (D10 bandinys) pasiekta esant 3,5 W galiai ir $1 \mathrm{~mm} / \mathrm{s}$ apdorojimo greičiui. Tai lèmé didžiausias (D10 bandinys) lazeriu apdoroto paviršiaus mikrokietumas $439 \mathrm{HV}$ (3.19 pav.).

Tyrimo metu nustatyta, kad trinties koeficiento reikšmès koreliuoja su neapdoroto bei D5 ir D10 bandinių paviršinio sluoksnio mikrokietumo reikšmėmis, atitinkamai $279 \mathrm{HV}, 401 \mathrm{HV}$ ir $439 \mathrm{HV}$.

\subsection{Cheminè analizè}

Selektyviojo lazerinio sukepinimo kokybę lemia žaliavos cheminė sudètis. Todèl itin svarbu ịsitikinti, kad tyrimams panaudoti milteliai atitinka gamintojo pateikiamą specifikaciją (2.1 lentelè). Cheminès sudèties tyrimas remiasi pagrindinių legiruojančiujų elementų bei deguonies, esančių žaliavos sudètyje analize. 3.3 lentelëje pateikiama lyginamoji miltelių, neapdoroto bei sukepinto ir lazerio spinduliuote apdoroto paviršiaus cheminè analizè.

3.3 lentelè. Miltelių cheminè sudètis, masès \%

Table 3.3. Chemical composition (in wt. \%) of the powder

\begin{tabular}{|c|c|c|c|c|c|c|}
\hline \multirow{2}{*}{ Žymuo } & \multicolumn{7}{|c|}{ Cheminė sudėtis } \\
\cline { 3 - 7 } & $\mathrm{Fe}$ & $\mathrm{Ni}$ & $\mathrm{Co}$ & $\mathrm{Mo}$ & $\mathrm{Ti}$ & $\mathrm{O}$ \\
\hline \multirow{3}{*}{ Žaliava } & 20 & 6,9 & 4,5 & 0,7 & 2 \\
\hline Neapdorotas & \multirow{3}{*}{ Likusi dalis } & 23 & 8,2 & 4,1 & 0,7 & 5 \\
\cline { 3 - 7 } & & 11,8 & 6,1 & 4 & 0,8 & 24 \\
\hline
\end{tabular}

Analizès rezultatai parodè, kad cheminè paviršinio sukepinto sluoksnio sudètis yra labai artima žaliavos cheminei sudečiai. Nikelio koncentracijos sumažejimas tarp neapdoroto ir lazerio spinduliuote paveikto paviršiaus nuo 23 iki 11,8 \% lèmè žemesnè nei geležies nikelio garavimo temperatūra $3005 \mathrm{~K}$. Dalis nikelio yra tiesiog išgarinama. Selektyvusis lazerinis sukepinimas vyksta apsauginių argono dujų aplinkoje, o lazerinis sukepinto paviršiaus mikroapdorojimas vyksta be apsauginès aplinkos. Deguonies koncentracijos paviršinio sluoksnio 
metale padidejjimo šuoli tarp neapdoroto ir lazerio spinduliuote paveikto paviršiaus nuo 5 iki $24 \%$ lemia aukšta apdorojimo zonos temperatūra ir difuziniai virsmai tarp bandinio paviršiaus ir supančios aplinkos. Deguonies prisotintame paviršiuje padideja intermetalinių junginių formavimosi tikimybè.

\subsection{Mikrostruktūros analizè}

Tiriamiesiems bandiniams gaminti naudoti Fe-Ni-Co pagrindo milteliai, kurie dažnai taikomi polimerų liejimo ịrangos pramonèje. Šio plieno detalėms gaminti pasaulyje taikomos dvi technologijos: tradicinè ir adityvinè gamyba. Tradicinès gamybos atveju naudojami apvalaus skerspjūvio ruošiniai ir valcuoti strypai. Tradicinei gamybai naudojama žaliava pasižymi išskirtine-martensitine struktūra. Čia liekamojo austenito ir intermetalinių junginių kiekis yra labai mažas (Jagle et al. 2010). Šis efektas pasiekiamas dèl aukštatemperatūio sendinimo 480 $510{ }^{\circ} \mathrm{C}$. Homogeniška struktūra užtikrina minimalius liekamuosius ịtempius, pastovias visame detalès tūryje mechanines ir fizikines charakteristikas, leidžia prognozuoti detalių ir mazgų ilgaamžiškumą bei kitas eksploatacines charakteristikas.

Selektyviojo lazerinio sukepinimo atveju situacija yra labiau komplikuota. Aukštų kokybès reikalavimų, keliamų žaliavai, nepakanka galutinio gaminio kokybei užtikrinti. Čia dèl specifinio šilumos ịvedimo, būdingo lazeriniam apdirbimui, sukepintų gaminių mikrostruktūra nėra tobula (3.28 pav.). Tradicinejje metalų gamybos ir apdirbimo pramonèje martensitinè gaminio struktūra yra užtikrinama naudojant terminị apdirbimą - grūdinimą. AM atveju martensitinè gaminio struktūra užtikrinama aukšta nikelio koncentracija (Jagle et al. 2010). Pagrindinis martensitinès struktūros bruožas - pailgi, adatos formos grūdeliai. Nevienalytis ir nekryptingas grūdèlių išsidėstymas matomas sukepinto bandinio paviršinio sluoksnio mikrostruktūroje (3.28 pav.). Tamsaus atspalvio plotai - tai liekamojo austenito bei priemaišų pėdsakai. Dèl apsauginių dujų, kenksmingų priemaišų kiekis po selektyviojo lazerinio sukepinimo yra minimalus.

Sukepinto ir papildomai lazerio spinduliuote mikroapdoroto bandinio paviršinio sluoksnio mikrostruktūra yra labai artima neapdoroto bandinio mikrostruktūrai. Akivaizdaus mikrostruktūros dedamujų skirtumo nebuvimas lazerio spinduliuote mikroapdoroto bandinio paviršiuje leidžia teigti, kad sukietinto sluoksnio storio nustatymas remiantis metalo struktūros dedamuju pokyčiu yra neịmanomas. Struktūros vienodumas taip pat byloja apie minimalius liekamuosius itempius sukepinto ir papildomai lazerio spinduliuote apdoroto bandinio paviršiuje. 


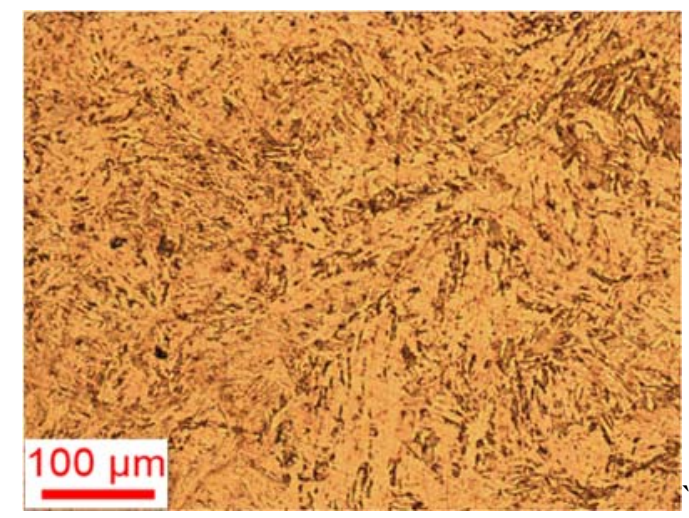

3.28 pav. Neapdoroto bandinio mikrostruktūra Fig. 3.28. Microstructure of non processed sample

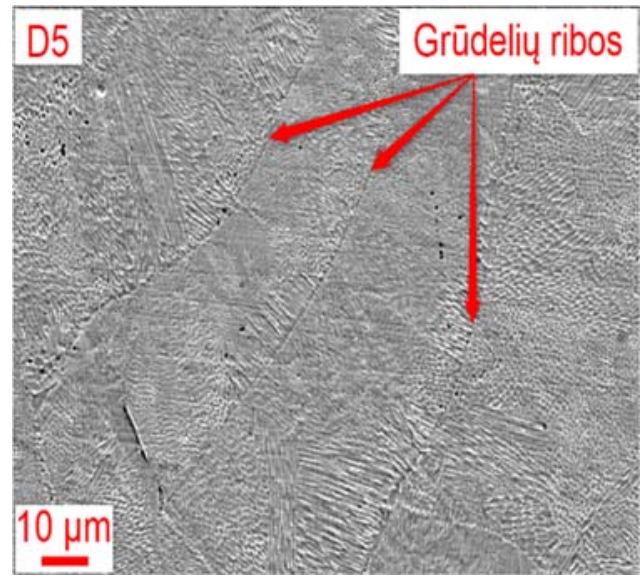

3.29 pav. Lazeriu apdoroto D5 bandinio mikrostruktūra

Fig. 3.29. Microstructure image of the laser processed sample

Tyrimo metu nustatyta (3.29 pav.) kad, lazeriu apdoroto paviršiaus mikrostruktūrą sudaro adatos formos grūdeliai. Grudelių paribių plotai pasižymi savita raižyta faktūra, kuri galimai susidarè dèl liekamojo austenito, esančio grūdèlių ribose. Literatūroje nurodoma, kad SLS būdu sukepinto Fe-Ni-Co miltelinio pagrindo metalo mikrostruktūroje yra liekamasis austenitas, kuris išsidèsto grūdèlių ribuose. (Jagle et al. 2010; Yasa et al. 2010; Kempen et al. 2010) nustatè, kad liekamojo austenito kiekis Fe-Ni-Co plienų, pagamintų AM technologija, yra apie $17 \%$. Jie taip pat pastebejo, kad intermetalinių junginių kiekis gaminio tūryje lemia jo kietumą. 


\subsection{Fazinè analizè}

Siekiant įvertinti paviršiaus fazinès sudėties pokyčius, sukeltus mikrolazerinio apdorojimo, bei pokyčiu priklausomybę nuo mikroapdorojimo parametrų, buvo atlikta sukepintų bei lazeriu apdorotų bandinių rentgeno difrakcinė analizė nustatant jų fazinę ir procentinę sudètį.

Ne tik rentgenogramose vaizduojamų intermetalinių junginių tankis, kiekis, bet ir oksidinių junginių koncentracija gali lemti lazeriu apdorotų paviršių mechanines ir eksploatacines charakteristikas.

SLS sukepinto ir neapdoroto bandinio paviršiaus difrakcinè kreivè pateikta 3.30 paveiksle. Intensyviausia kreivès smailè ir smailè, kuri susiformavo kreivèje esant $2 \theta$ kampui apie $64,5^{\circ}$, atitinka kubinę centratūrę kristalinę gardelę su parametru a = 2,866 ̊̊. Tokio tipo gardelè yra būdinga „kubiniam“ martensitui, kuris susiformuoja grūdinant mažai anglies turinčius plienus. Kitos smailès atitinka austenito kubinę centrapaviršę gardelę su parametru a = 3,63 A. Remiantis šia analize nustatyta, kad tiriamojo bandinio paviršinio sluoksnio metalo struktūrą sudaro martensitinè struktūra su KCT gardele ir liekamasis austenitas.

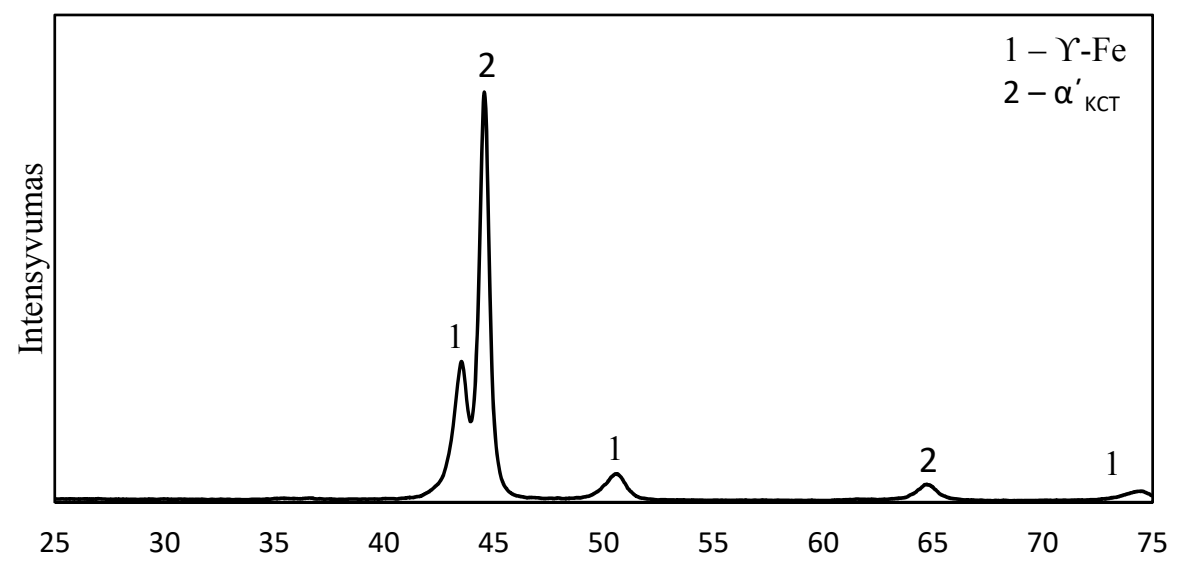

Difrakcijos kampas 20, laipsniais

3.30 pav. Lazeriu neapdoroto bandinio rentgeno difrakcinè kreivè

Fig. 3.30. Rentgen difraction analyse of the non processed sample

Remiantis 3.30-3.33 paveiksluose pateiktų difrakcinių kreivių analize nustatyta, kad dèl lazerinès spinduliuotès poveikio tiriamujų bandinių paviršiuose susidare liekamasis austenitas ir molibdeno nikelio tarpmetalinio junginio fazé bei kobalto geležies $\mathrm{CoFe}_{2} \mathrm{O}_{4}$, titano kobalto $\mathrm{Ti}_{0,11} \mathrm{Co}_{0,89} \mathrm{O}_{0,99}$ ir geležies $\mathrm{Fe}_{3} \mathrm{O}_{4}$ oksidai. 


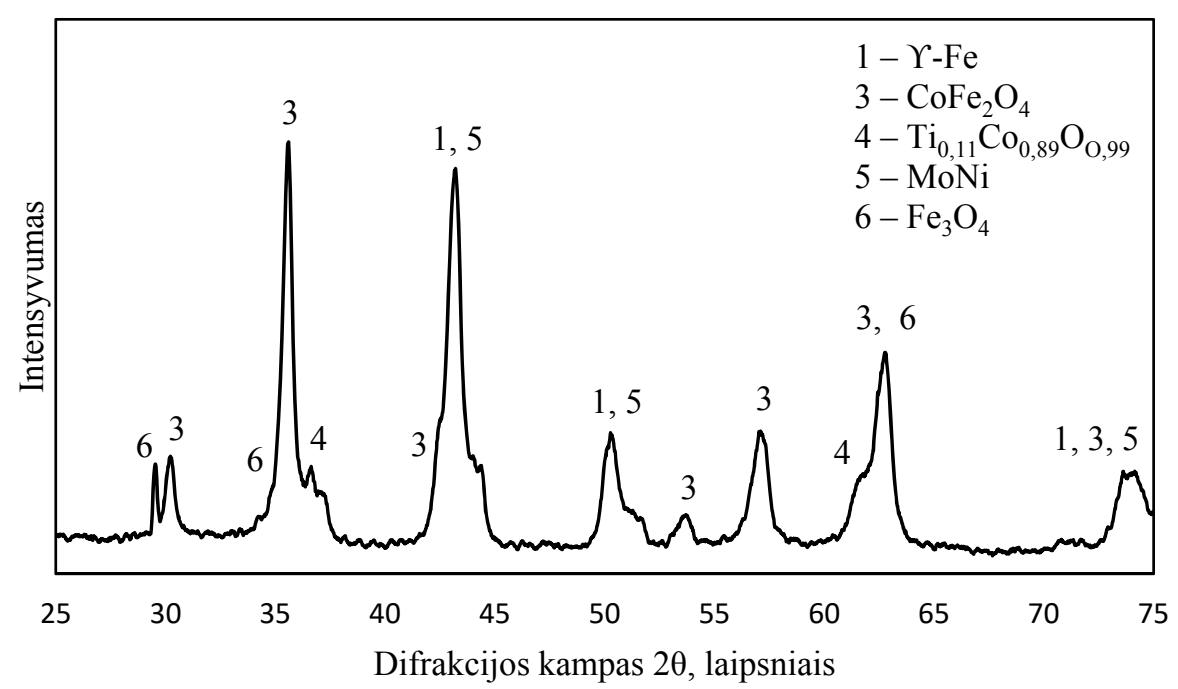

3.31 pav. Lazeriu apdoroto bandinio D4 rentgeno difrakcinè kreivè

Fig. 3.31. XRD pattern of the D4 sample

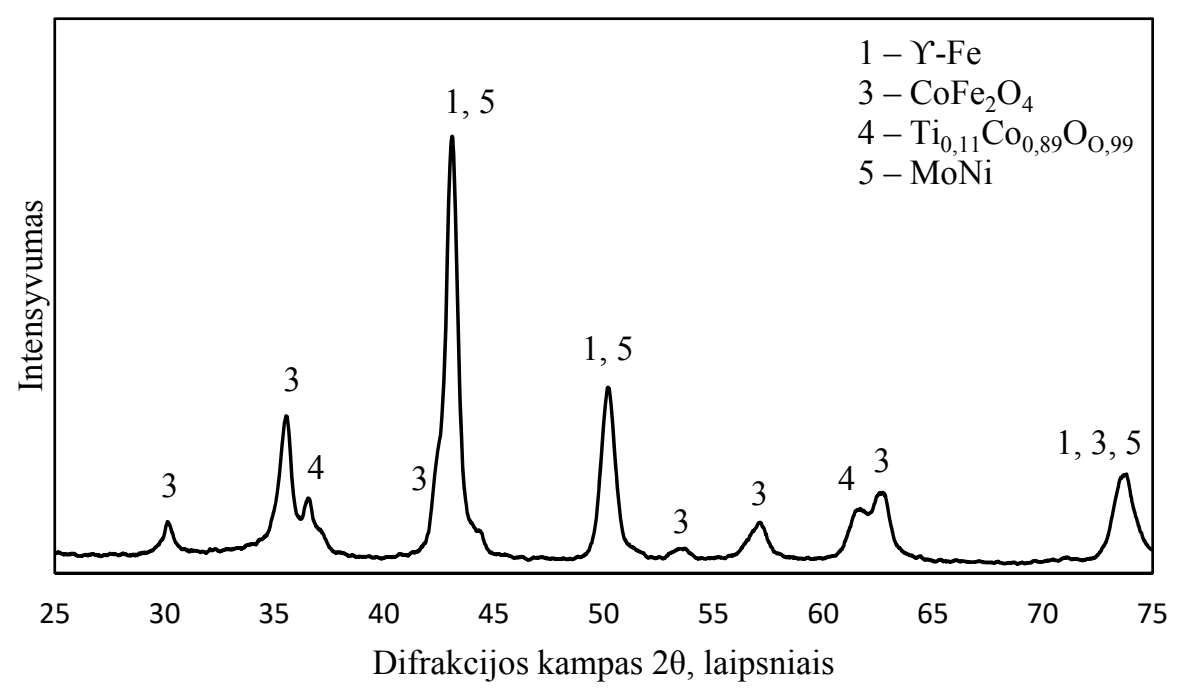

3.32 pav. Lazeriu apdoroto bandinio D5 rentgeno difrakcinè kreivè

Fig. 3.32. XRD pattern of the D5 sample 


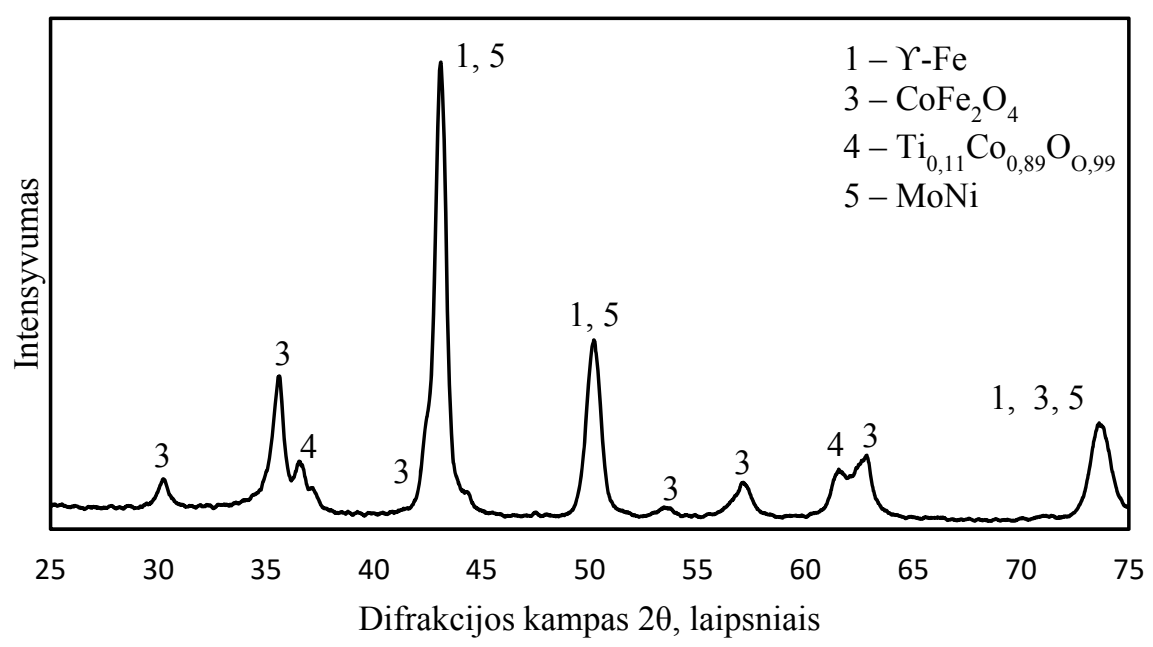

3.33 pav. Lazeriu apdoroto bandinio D6 rentgeno difrakcinè kreivė

Fig. 3.33. XRD pattern of the D6 sample

Tikètina, kad susiformavę kietieji oksidai lèmè didesnị lazeriu apdorotų bandinių kietị.

Taikant Ritveldo metodą, buvo atliktas RSDA eksperimentinių rezultatų apdorojimas, kuris leido apskaičiuoti bandiniuose aptiktų fazių procentinị santykị. RSDA nustatyta, kad apdorotų bandinių paviršiuose susiformuoja liekamasis austenitas ir molibdeno nikelio tarpmetalinis junginys bei geležies kobalto, titano kobalto ir geležies oksidai. Kietumo padidejjimui didžiausią poveikį turi didelio kietumo fazès, tokios kaip: titano kobalto bei geležies kobalto oksidai. 3.4 lentelëje pateikiama bendra kietujjų oksidų koncentracija (\%) bandinių paviršiuose, apdorotuose esant 2,5 W lazerio spindulio pluošto galiai ir taikant skirtingą apdorojimo greitị.

Mikrolazerinio apdorojimo greičio didinimas nuo $1 \mathrm{~mm} / \mathrm{s}$ iki $5 \mathrm{~mm} / \mathrm{s}$ esant 2,5 W galiai, lemia kietujų metalo oksidų koncentracijos sumažejimą nuo $70 \%$ iki $36 \%$ (3.4 lentelè). Analogiškas mikrolazerinio apdorojimo greičio pokytis esant $3 \mathrm{~W}$ galiai, lemia kietujų metalo oksidų koncentracijos sumažejjimą nuo $68 \%$ iki $37 \%$. Lazerinio mikroapdorojimo greičio didinimas lemia kietujų metalo oksidų koncentracijos sumažèjimą. Tai susiję su mažesne lazeriu mikroapdoroto paviršiaus temperatūra, trumpesniu poveikio laiku bei paviršiaus metalo oksidaciniais procesais. Ši nustatyta priklausomybè koreliuoja su SLS būdu sukepintų ir lazeriu mikroapdorotų paviršių mikrokietumo pokyčiais didinant apdorojimo greitị (žr. 3.17 ir 3.19 pav.). 
3.4 lentelè. Sukepinto ir lazeriu apdoroto metalo paviršinio sluoksnio oksidų koncentracija, \%

Table 3.4. Concentration of oxides in the sintered and laser processed surface metal layer, $\%$

\begin{tabular}{|c|c|c|c|}
\hline $\begin{array}{c}\text { Bandinio } \\
\text { žymuo }\end{array}$ & $\begin{array}{c}\text { Ivedamos energijos } \\
\text { lygmuo }\end{array}$ & $\begin{array}{c}\text { Apdorojimo } \\
\text { greitis, } \mathrm{mm} / \mathrm{s}\end{array}$ & $\begin{array}{c}\text { Kietujų oksidų } \\
\text { koncentracija, } \%\end{array}$ \\
\hline D4 & E3 & 1 & 70 \\
\hline D5 & E2 & 2,5 & 61 \\
\hline D6 & E1 & 5 & 36 \\
\hline
\end{tabular}

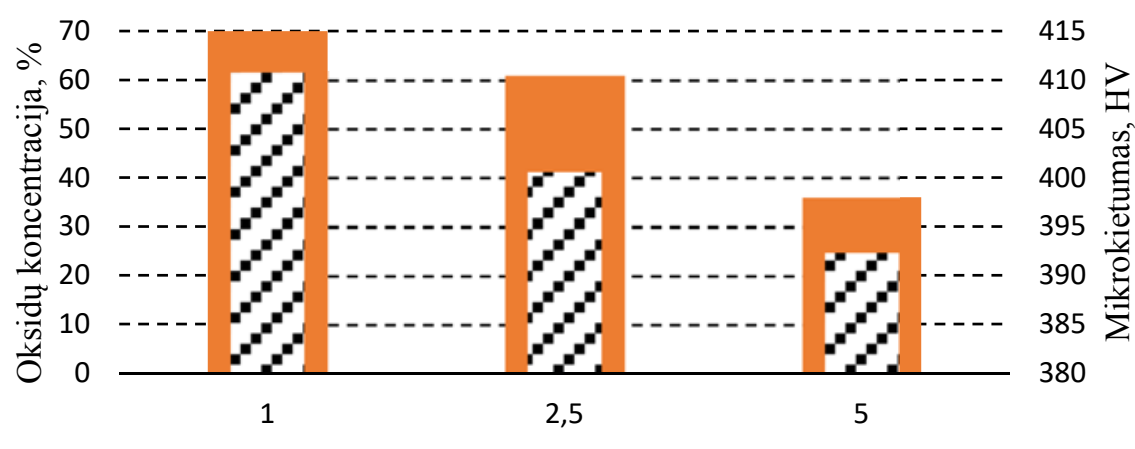

Apdirbimo greitis $v, \mathrm{~mm} / \mathrm{s}$

- Kietujų oksidų koncentracija, \% Mikrokietumas, HV

3.34 pav. Selektyviuoju lazerinio sukepinimo būdu pagamintų ir lazeriu mikroapdorotų bandinių kietumo priklausomybė nuo kietujų oksidų koncentracijos esant skirtingam apdirbimo greičiui

Fig. 3.34. The dependence of hardness of selective laser sintering-made specimens after their laser microprocessing on the concentration of solid oxides at different processing speeds

Sukepintų ir lazeriu mikroapdorotų bandinių paviršinio metalo sluoksnio kietumo ir kietujų oksidų koncentracijos verčių palyginimas pateiktas 3.34 paveiksle.

Tyrimo metu nustatyta, kad lazeriu 2,5 W galia apdorojant sukepintą paviršių esant $1 \mathrm{~mm} / \mathrm{s}$ apdorojimo greičiui (E1 lazerinio apdorojimo ịvedamos energijos lygmuo) lazeriu mikroapdoroto viršutinio paviršiaus mikrokietumas siekia $411 \mathrm{HV}$, kai kietujų oksidų koncentracija yra apie 70 \%. Esant apdirbimo greičio didinimui nuo $1 \mathrm{~mm} / \mathrm{s}$ iki 2,5 mm/s, lazeriu apdoroto paviršiaus mikrokietumas sumažèja iki $401 \mathrm{HV}$, o kietujų oksidų koncentracija sumažèja iki $61 \%$. 
Didžiausiu greičiu apdorojant SLS būdu sukepintą paviršių, kai $V=5 \mathrm{~mm} / \mathrm{s}$, lazeriu apdoroto paviršiaus mikrokietumas siekia $392 \mathrm{HV}$, o kietujų oksidų koncentracija atitinkamai sumažeja iki $36 \%$.

SLS būdu sukepinto ir lazeriu mikroapdoroto paviršiaus mikrokietumo verčių sumažejjimą lèmė metalo paviršinio sluoksnio kietųjų oksidų koncentracijos pokytis nuo $70 \%$ iki $36 \%$ esant lazerinio mikroapdorojimo greičio didinimui nuo $1 \mathrm{~mm} / \mathrm{s}$ iki $5 \mathrm{~mm} / \mathrm{s}$ atitinkamai pereinant nuo 3 iki 1 lazerinio apdorojimo ivedamos energijos lygmens.

Remiantis lazeriu mikroapdorotų bandinių fazine analize galima teigti, kad metalų oksidų koncentracija ir tarpmetalinių junginių formavimas paviršiniame lazeriu mikroapdorotame sluoksnyje lemia jo mikrokietį.

\subsection{Atsparumas elektrocheminei korozijai}

Tyrimams naudojama Fe-Ni-Co miltelių pagrindu sukepinta medžiaga dažnai taikoma plastiko liejimo formų gamyboje. Čia dèl didelio išsiskiriančių dujų poveikio itin pageidaujamas darbinių įrangos detalių atsparumas korozijai. Plastiko liejimo formos eksploatavimas darbiniams paviršiams esant neatspariems korozijai yra neleistinas.

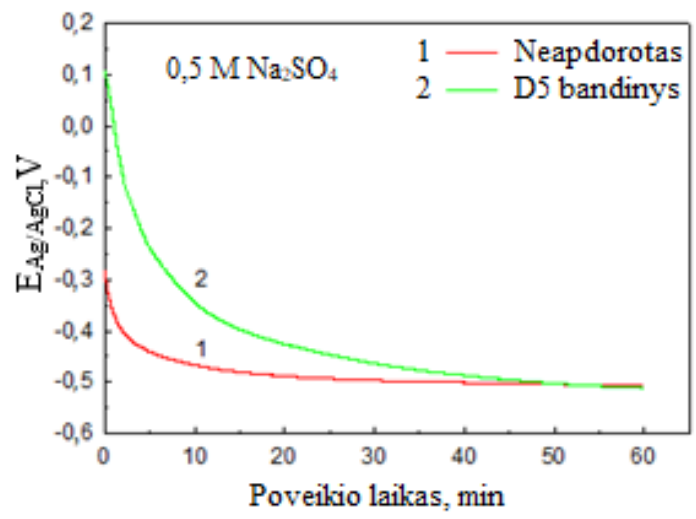

3.35 pav. Sukepintų bandinių atviros grandinès potencialų $\left(E_{\text {ocp }}\right)$ priklausomybès nuo ekspozicijos laiko $0,5 \mathrm{M} \mathrm{Na}_{2} \mathrm{SO}_{4}$ tirpale

Fig. 3.35. Open circuit potentials (Eocp) reliation from exposure time of the sintered samples (in $0,5 \mathrm{M} \mathrm{Na}_{2} \mathrm{SO}_{4}$ solution)

Sukepintų bandinių atviros grandinès potencialų priklausomybè nuo ekspozicijos laiko yra vaizduojama 3.35 paveiksle. Ne tik potencialo matematinè verte, bet ir pokyčio sparta rodo analizuojamos medžiagos atsparumą korozijai. 
Esant 10 min. poveikiui, potencialo pokytis neigiamų srovių diapazone neapdoroto bandinio atveju sudare $0,57 \mathrm{~V}$, o D5 bandinio $0,45 \mathrm{~V}$. Kuo didesnis potencialo pokytis, tuo korozijos proceso intensyvumas yra didesnis. Potencialo verčių bei pokyčio spartos skirtumas matomas iki 50 poveikio laiko minutės. Nuo 50 iki $60 \mathrm{~min}$. korozinio atsparumo rodikliai abiejų bandinių atveju yra vienodi.

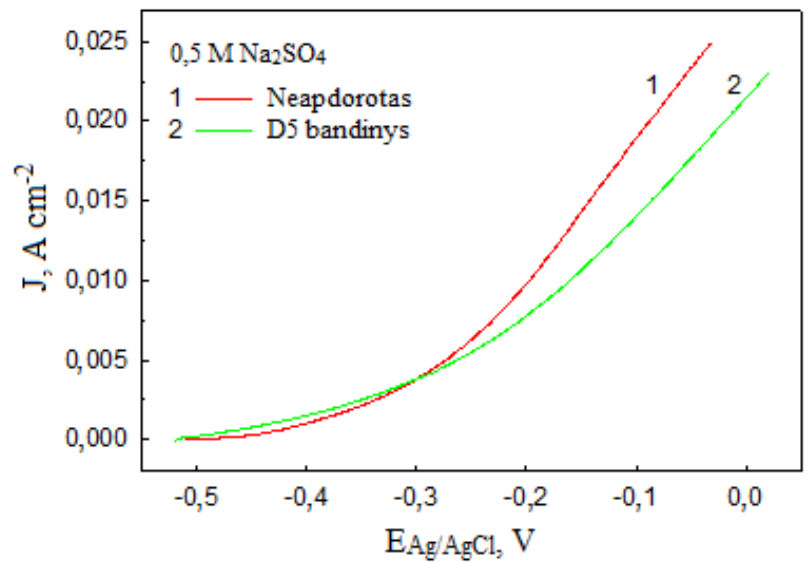

3.36 pav. Sukepintų bandinių potenciodinaminès poliarizacijos kreivès $0,5 \mathrm{M} \mathrm{Na}_{2} \mathrm{SO}_{4}$ tirpale

Fig. 3.36. Potenciodynamic poliarization curves of the sintered samples (in $0,5 \mathrm{M} \mathrm{Na}_{2} \mathrm{SO}_{4}$ solution)

Sukepintų bandinių anodinès poliarizacijos kreivès yra vaizduojamos 3.36 paveiksle. Anodinès poliarizacijos kreivių skirtumas tarp neapdoroto ir apdoroto bandinio D5, potencialo vertėms esant nuo $-0,5 \mathrm{~V}$ iki $-0,3 \mathrm{~V}$, nèra stebimas. Tai reiškia, kad šioje diagramoje vaizduojamų reikšmių atkarpoje korozinis abiejų bandinių atsparumas yra analogiškas. $\mathrm{O}$ potencialų intervale nuo $-0,3 \mathrm{~V}$ iki $0,05 \mathrm{~V}$ pastebimas nedidelis korozinès srovès tankio skirtumas. Esant $-0,1 \mathrm{~V}$ potencialui neapdoroto bandinio korozinès srovès tankis siekia $0,17 \mathrm{~A} / \mathrm{cm}^{-2}$, o lazeriu apdoroto bandinio D5 $0,11 \mathrm{~A} / \mathrm{cm}^{-2}$. Korozinès srovès tankio vertès yra proporcingos tiriamos medžiagos gebai priešintis korozijai. Kuo didesnès korozinès srovès tankis, tuo medžiaga labiau pažeidžiama korozijos. $\mathrm{E}_{\mathrm{Ag} / \mathrm{AgCl}}, \mathrm{V}$.

\subsection{Trečiojo skyriaus išvados}

1. Mikroskopijos tyrimo metu nustatyta, kad Fe-Ni-Co milteliu pagrindu sukepintam ir papildomai neapdorotam paviršiui būdingas skirtingos krypties didelis paviršiaus netolygumas, formuojasi ryškūs iš- 
gaubti aplydymo sluoksniai, šoninio paviršiaus šiurkštis siekia $R_{a}=$ $9,2 \mu \mathrm{m}$, o viršutinio $R_{a}-17,9 \mu \mathrm{m}$.

2. SLS būdu sukepintų, papildomai šlifuotų ir lazeriu mikroapdorotų bandinių paviršiaus morfologijos ir topografijos tyrimais nustatyta, kad esant 2,5 W apdorojimo galiai, $2,5 \mathrm{~mm} / \mathrm{s}$ apdorojimo greičiui buvo pasiekta geriausia topografija. Tyrimo metu nustatyta, kad lazerinio mikroapdorojimo ejjimų skaičiaus didinimas lemia įtrūkių atsiradimą paviršiniame metalo sluoksnyje.

3. SLS būdu sukepintų ir lazeriu mikroapdorotų šoninių bandinių paviršių morfologijos ir topografijos tyrimais nustatyta, kad lazeriu mikroapdorojant šoninị sukepintą paviršių formuojasi trys esminès apdoroto paviršiaus faktūros: korèta ir nepakankamai išsilydžiusi, netvarkingai išgarinta su chaotiškai išsiděšciusiais iškilimais ir tolygiai bei kryptingai išgarinta. Tyrimų metu nustatyta, kad esant E2 ivvedamos energijos lygmeniui užtikrinamas mažiausias paviršiaus mikronelygumų aukštis $R_{a}=4,27 \mu \mathrm{m}$ (esant 2,5 W galiai ir 4 ejjimų skaičiui). Ėjimų skaičiaus didinimas nuo 1 iki 4 lemia sukepinto ir lazeriu apdoroto paviršiaus šiurkštumo reikšmès sumažèjimą apie 21 $\%$ ir jo eksploatacinių savybių pagerejjimą. Dar daugiau didinant mikrolazerinio apdorojimo èjimų skaičių, apdoroto bandinio paviršiuje formuojasi ịtrūkiai.

4. SLS būdu sukepintų ir lazeriu mikroapdorotų viršutinių bandinių paviršių morfologijos ir topografijos tyrimais nustatyta, kad esant E2 ivvedamos energijos lygmeniui formuojasi geriausia paviršiaus faktūra, pasižyminti mažiausiu paviršiaus mikronelygumų aukščiu $R_{a}=$ $6,22 \mu \mathrm{m}$ (esant 2,5 W galiai ir 1 ejjimų skaičiui). Tyrimų metu nustatyta, kad lazeriu mikroapdorojant viršutinị sukepintą paviršių daugiau nei 1 ejimu, skatinamas paviršiaus mikronelygumų aukščio rodiklių padidèjimas iki $R_{a}=18,41 \mu \mathrm{m}$, kai $n=4$, nes bandinio paviršiuje pasireiškia medžiagos pleišèjimas ir susiformuoja įtrūkiai.

5. Tyrimo metu nustatyta, kad didinant lazerio galią bei ịvedamos energijos kiekị (esant perèjimui nuo pirmo iki trečio ịvedamos energijos lygmens) viršutinio ir šoninio paviršiaus mikrokietumas didèja nuo 372 iki 439 HV ir nuo 509 iki 558 HV atitinkamai.

6. Mikrokietumo tyrimo metu nustatyta, kad lazeriu mikroapdorojant sukepintą bandini viršutinio ir šoninio paviršiaus metalo mikrokietumas padideja iki $48 \%$ ir iki $88 \%$ atitinkamai. Lazerinio mikroapdorojimo ejjimų skaičiaus didinimas neturi ịtakos metalo paviršinio sluoksnio mikrokietumui. 
7. Tribologinių savybių ir atsparumo dilimui tyrimo metu nustatyta, kad lazeriu mikroapdorojant sukepintą bandinị viršutinio ir šoninio paviršiaus metalo trinties koeficientas sumažèja $19 \%$ ir $63 \%$, o lazeriu mikroapdoroto metalo paviršinio sluoksnio dilimo greitis -17 ir 39 kartų atitinkamai.

8. Mikrostruktūros tyrimo metu nustatyta, kad sukepintam bandinio metalui būdinga nevienalyte, nekryptingai išsidèsčiusių adatinių grūdelių struktūros morfologija, o mikrostruktūrą sudaro martensitas, liekamasis austenitas ir priemaišos. Tyrimo metu nustatyta, kad sukepinto ir lazeriu mikroapdoroto paviršiaus mikrostruktūrą sudaro adatos formos grūdeliai. Grudelių paribių plotai pasižymi savita raižyta faktūra, kuri galimai susidarè dèl liekamojo austenito, esančio grūdelių ribose.

9. Fazinès analizès metu nustatyta, kad sukepinto bandinio metalą sudaro kubinę centratūrę kristalinę gardelę turintis martensitas ir liekamasis austenitas. Sukepinto ir lazeriu mikroapdoroto metalo paviršiniame sluoksnyje be pagrindinių metalo matricą sudarančių fazių formuojasi ịvairūs geležies, kobalto ir kitų metalų oksidai. Suminè oksidų koncentracija metalo paviršiuje didejja mažinant lazerinio mikroapdorojimo greiti, t. y. didinant ịvedamos energijos kiekị.

10. Tyrimo metu nustatyta, kad besiformuojantys metalo oksidai ir jų koncentracija lemia sukepinto ir lazeriu mikroapdoroto paviršiaus mikrokietumą.

11. Korozinio atsparumo tyrimo metu nustatyta, kad lazerinis sukepinto Fe-Ni-Co miltelinio pagrindo paviršiaus mikroapdorojimas neturi neigiamos įtakos lazeriu mikroapdoroto paviršiaus koroziniam atsparumui. 



\section{Bendrosios išvados}

1. Fe-Ni-Co miltelių pagrindu sukepintų SLS būdu gaminių papildomo lazerinio mikroapdorojimo technologija leidžia modifikuoti sukepintą metalą. Nustatytas SLS būdu sukepinto miltelinio Fe-Ni-Co pagrindo metalo paviršinio sluoksnio lazerinio mikroapdorojimo poveikis (lazerio spindulio pluošto galios, apdirbimo greičio ir ejjimų kiekio) sluoksnio formavimosi procesui bei jo fizikinèms savybèms (mikrokietumui, dilimo greičiui, paviršiaus mikronelygumų aukščiui, atsparumui korozijai ir $\mathrm{kt}$.).

2. SLS būdu sukepinto ir lazeriu mikroapdoroto Fe-Ni-Co miltelinio pagrindo topografija priklauso nuo lazerinio apdorojimo įvedamos energijos lygmens. Esant apdorojimo greičiui $V=2,5 \mathrm{~mm} / \mathrm{s}$; apdirbimo galiai $P=$ $2,5 \mathrm{~W}$, lazerinio mikroapdorojimo režimui šoninio ir viršutinio paviršių (vertikalus ir horizontalus paviršiai) šiurkščio parametras $R_{a}$ sumažejja $54 \%$ ir $65 \%$ bei sudaro $R_{a}=4,27 \mu \mathrm{m}$ ir $R_{a}=6,22 \mu \mathrm{m}$ atitinkamai.

3. SLS būdu sukepinto ir lazeriu mikroapdoroto Fe-Ni-Co miltelinio pagrindo paviršiaus kietumas priklauso nuo lazerinio apdorojimo metu paviršiniame metalo sluoksnyje susidarančių kietujjų oksidų $\mathrm{CoFe}_{2} \mathrm{O}_{4}$ ir $\mathrm{Ti}_{0,11} \mathrm{Co}_{0,89} \mathrm{O}_{0,99}$ koncentracijos. Didejjant kietujų oksidų koncentracijai, paviršinio metalo sluoksnio mikrokietumas dideja. Esant apie 70 \% kietujų oksidų koncentracijai $(P=2,5 \mathrm{~W} ; V=2,5 \mathrm{~mm} / \mathrm{s})$, sukepinto ir lazeriu mikroapdoroto šoninio ir viršutinio paviršių mikrokietumas padi- 
dejja $88 \%$ ir $48 \%$ lyginant su lazeriu neapdorotais paviršiais ir sudare $558 \mathrm{HV}$ ir $439 \mathrm{HV}$ atitinkamai.

4. SLS būdu sukepinto ir lazeriu mikroapdoroto Fe-Ni-Co miltelinio pagrindo paviršiaus dilimo greitị lemia kompleksinis lazeriu apdoroto metalo paviršinio sluoksnio mikrokietumo bei morfologijos pokytis. Padidèjęs šoninio (nuo $71 \%$ iki $88 \%$ ) ir viršutinio nuo (25\% iki $48 \%$ ) paviršių mikrokietumas bei šoninio paviršiaus vidutinio mikronelygumų aukščio sumažèjimas $54 \%$ o viršutinio $65 \%$ (esant $P=2,5 \mathrm{~W} ; V=$ $2,5 \mathrm{~mm} / \mathrm{s}$ ) lyginant su neapdorotu bandiniu lemia sukepinto ir lazeriu mikroapdoroto šoninio ir viršutinio paviršių dilimo greičių mažèjimą 39 ir 17 kartų atitinkamai. 


\section{Literatūra ir šaltiniai}

Abouridouane, M., Klocke, F., Dobbeler, B. 2017. Characterisation and modelling of the machinability of ferritic-pearlitic steels in drilling operations, Procedia CIRP 25: 79-84.

Amend, P., Pscherer, C., Rechtenwald, T., Frick, T., Shmidt, M. 2010. A fast flexible method for manufacturing 3D molded interconnect devices by the use of a rapid prototyping technology, Physics procedia 5: 561-572.

Aniolek, K., Kupka, M., Barylski, A. 2016. Sliding wear resistance of oxide layers formed on a titanium surface during thermal oxidation, Wear 23: 356-357.

Aniolek, K., Kupka, M., Barylski, A., Dercz, G. 2016. Mechanical and tribological properties of oxide layers obtained on titanium in the thermal oxidation process, Applied Surface Science 357 (B): 1419-1426.

Balachninaite, O., Bargelis, A., Dementjev, A., Jonušas, R., Račiukaitis, G., Sirutkaitis, V. 2008. Lazerine technologija.Vilniaus universiteto leidykla.

Bauereiss, A., Scharowsky, T., Korner, C. 2014. Defect generation and propagation mechanism during additive manufacturing by selective beam melting, Journal of materials processing technology 214 (11): 2522-2528.

Bhaduri, D., Penchev, P., Dimov, S., Soo, S. 2016. An investigation of accuracy, repeatability of laser micromachining systems, Measurements 88: 248-261.

Binder, M., Klocke, F., Doebbeler, B. 2017. An advanced numerical approach on tool wear simuliation for tool and process design in metal cutting, Simuliation modelling practise and theory 22: 65-82. 
Biswas, A., Majumdar, J. 2009. Surface characterization and mechanical property evaluation of thermally oxidized Ti-6Al-4V, Materials Characterization 60 (6): 513-518.

Black, S., Jobling, L. 2014. Physical principles of laser, Anaesthesia and intesive care medicine 15: 530-532.

Bouquet, J., Van Camp, D., Malek, O., Haaf Ten, P., Vanmeensel, K., Lauwers, B. 2016. Aiming for improved lifetime of die and mold components through an integrated laser hardening operation, combining machining and selective heat treatment in one step, Procedia CIRP 46: 541-544.

Brandt, M. 2017. The role of lasers in additive manufacturing enviroment, Laser additive manufacturing 5 (A): 65-80.

Cadot, G., Axinte, D., Billingham, J. 2016. Continous trench, pulsed laser ablation for micro machining applications, International journal of machine tools and manufacture 107: 8-20.

Castanhera, I., Diniz, A. 2016. High speed machining of hardened steel convex surface, Procedia manufacturing 5: 220-231.

Chavoshi, S., Goel, S., Morantz, P. 2017. Current trends and future of sequential micro machining processes on a single machine tool, Materials and design 127: 37-53.

Cheng, J., Liu, Ch., Shang, S., Liu, D., Perrie, W., Dearden, G., Watkins, K. 2013. A review of ultrafast laser materials micromachining, Optics \& laser technology 46: 88102.

Choudhury, S., Chinchanikar, S. 2017. Finish machining of hardened steel, Comprehensive materials finishing 1: 47-92.

Chroma. [interaktyvus] 2017. [Žiūrèta 2017 m. gegužès 2 d.] Prieiga per internetą: www.chroma.com

Cui, W., Jiao, F. P., Ming, O. 2017. Reliability analysis of ceramic cutting tools in continous and interrupted hard turning, Ceramics international 43 (13): 10109-10122.

Dahotre, N., Samant, A. 2011. Laser Machining of advanced materials. New York: CRC Press. 236 p.

Demir, A., Pangovski, K., O`Neill, W., Previtali, B. 2014. Laser micromachining of TiN coatings with variables pulse durations and shapes in ns regime, Surface and coatings technology 258: 240-248.

Ding, Z., Li, B., Fergani, O., Shao, Y., Liang, S. 2016. Investigation of temperature and energy partition during maraging steel micro granding, Procedia CIRP 56: 284-288.

Dohr, J., Armstrong, D., Tarleton, E., Couvant, T., Perez, S. 2017. The influence of surface oxides on the mechanical response of oxidized grain boundaries. Thin Solid Films 632: $17-22$.

Engineering inform, inspire. [interaktyvus] 2017. [Žiūrèta 2017 m. gegužès 8 d.] Prieiga per internetą: www.engineering.com 
Farahmand, P., Kovacevic, R. 2014. An experimental - numerical investigation of heat distribution and stress field in single - and multi - track laser cladding by high - power direct diode laser, Optics \& Laser Technology 63: 154-158.

Fimark Ltd. [interaktyvus] 2017. [Žiūrèta 2017 m. gegužès 5 d.] Prieiga per internetą: www.fimark.co.uk

Fousova, M., Vojtech, D., Kubasek, J., Jablonska, E., Fojt, J. 2017. Promising characteristics of gradient porosity $\mathrm{Ti}-6 \mathrm{Al}-4 \mathrm{~V}$ alloy prepared by SLM process, Journal of the mechanical behavior of biomedical materials 69: 368-376.

Francis, L. 2016. Chapter 5 - powder processes. Materials processing. 343-414.

Fusione. [interaktyvus] 2017. [Žiūrèta 2017 m. gegužès 3 d.] Prieiga per internetą: www.fusione.enea.it

Gaub, H. 2016. Customization of mass - produced parts by combining injection molding and additive manufacturing with industry 4.0 technologies, Reinforced plastics 60 (6): 401-404.

Gibson, I., Rosen, D., Stucker, B. 2015. Additive manufcturing technologies. New York: Springer. $498 \mathrm{p}$.

Gillner, A., Holtkamp, J., Hartmann, C., Olowinsky, A., Gedicke, J., Klages, K., Bosse, L., Bayer, A. 2005. Laser applications in microtechnology, Journal of materials processing technology 163 (2): 494-498.

Gross, S., Eckert, U., Edelmann, J. 2016. New sequential manufacturing process for micro and finishing machining, Procedia CIRP 46: 559-562.

Gu, D., Shen, Y. 2009. Effects of processing parameters on consolidation and microstructure of $\mathrm{W}-\mathrm{Cu}$ components by DLMS, Journal of alloys and compounds 10 (4): 107-115.

Gurr, M., Mulhaupt, R. 2012. Rapid prototyping, Comprehesive referece 8: 77-99.

Gusarov, A., Laoui, T., Froyen, L., Titov, V. 2003. Contact thermal conductivity of a powder bed in selective laser sintering, International journal of heat and mass transfer 46 (3): 1103-1109.

Haudet, S., Rodriguez, M., Carranza, R. 2015. Determing the effect of the main alloying elements on localized corrosion in Nickel alloys using artificial neural networks, Procedia materials science 8: 21-28.

Hong, S., Lee, H., Ko, S. 2016. Digital selective laser methods for nanomaterials: From synthesis to processing, Nanotoday 11 (5): 547-564.

Hu, J., Dang, D., Shen, H., Zhang, Z. 2011. A finite element model using multi - layered shell element in laser forming, Optics and laser technology 44 (4): 1148-1155.

Huang, Y., Yang, L., Du, Y. Y. 2016. Finite element analysis of thermal behavior of metal powder during selective laser melting, International journal of thermal science 104: 146-157. 
Yadollahi, A., Shamsaei, N., Thompson, S., Elwany, A., Bian, L. 2017. Effects of building orientation and heat treatment on fatigue behavior of selective laser melted $17-4$ PH stainless steel, International journal of fatigue 94 (2): 218-235.

Yang, X., Tang, J. 2014. Research on manufacturing method of CNC plunge milling for spur face-gear, Journal of materials processing technology 214 (2): 3013-3019.

Yasa, E., Kempen, K., Kruth, K. 2011. Microstructure and mechanical properties of maraging steel after selective laser melting, Physics procedia 12 (A), 383-396.

Yilbas, B., Arif, A. 2010. Laser cutting of steel and thermal stress development, Optics and laser technology 43 (4): 830-837.

Innovative manufacturing technology. [interaktyvus] 2017. [Žiūrèta $2017 \mathrm{~m}$. gegužès 6 d.] Prieiga per internetą: www.imt-c.co.kr

Yu, J., Lin, X., Ma, L., Wang, J., Fu, W., Chen, J., Huang, W. 2010. Influence of laser deposition patterns on part distortion, interior quality and mechanical properties by laser solid forming, Materials science and engineering 528 (3): 1094-1104.

Ivanova, T. 2016. Design and technology support of the grinding process for heavilymachined steel sheets, Procedia engineering 150: 782-788.

Jiang, W., Nair, R., Molian, P. 2005. Functionally graded mold inserts by laser - based flexible fabrication: processing modeling, structural analysis, and performance evaluation, Journal of materials processing and technology 166 (2): 286-293.

Kempen, K., Yasa, E., Thijs, L., Kruth, J., Humbeeck, J. 2011. Microstructure and mechanical properties of selective laser melted $18 \mathrm{Ni}-300$ steel, Physics procedia 12 (A): 255-263.

Kumar, A., Yadava, V. 2007. International journal of machine tools and manufacture. Laser beam machining 45 (6): 609-628.

Kumar, S. 2009. Manufacturing of WC - Co moulds using SLS machine, Journal of materials processing technology 209 (8): 3840-3848.

Kumar, S. 2014. Selective laser sintering / melting, Journal of Materials Processing Technology 212: 93-134.

Leong, K., Liu, D., Chua, C. 2015. Tissue engineering applications of additive manufacturing, Comprehensive materials processing 69: 251-264.

Lombardo, S. S., Boninelli, F., Cristiano, G., Fisicaro, G., Fortunato, M. G., Grimaldi, G., Impellizzeri, M., Italia, A., Marino, R., Milazzo, E., Napolitani, V., Privitera, A. 2017. Laser annealing in Si and Ge: Anomalous physical aspects and modeling approaches, Material science and semiconductor processing 62: 80-91.

Lonardo, P., Bruzzone, A. 2000. Measurement and topography characterisation of surfaces produced by selective laser sintering, Cirp annals - manufacturing technology 49 (1): 427-430. 
Long, L., Liu, Q., Zhong, Z., Xiong, L., Shi, T. 2015. Experimental study on the process of laser - enhanced electrochemical micromachining stainless steel, Optik - international journal for light and electron 126 (19): 1862-1829.

Ma, M., Wang, Z., Gao, M., Zen, X. 2014. Layer thickness dependence of performance in hihg - power selective laser melting of Cr18Ni9Ti stanless steel, Journal of materials processing technology 215: 142-150.

Maeda, K., Childs, T. 2004. Laser sintering (SLS) of hard powders for abrasion resistant coatings, Journal of materials processing technology 149 (1): 609-615.

Makinen, M., Jauhiainen, E., Matilainen, V., Riihimaki, J., Ritvanen, J., Piili, H., Salminen, A. 2015. Prelimanary comparison of properties between $\mathrm{Ni}$ - eelctroplated stainless steel parts fabricated with laser additive manufacturing and conventional machining, Physics procedia 78: 337-346.

Manzirov, A. 2017. Advances in the theory of surface growth with applications to additive manufacturing technologies. Procedia Engineering 173: 11-16.

Martinez, S., Lamikiz A., Tabernero, I., Ukar, E. 2012. Laser hardening process with 2D scanning optics, Sciverse science direct 39: 309-317.

Martinez, S., Lamikiz, A., Ukar, E., Calleja A., Arrizubieta, J. A., Lopez de Lacalle, L. N. 2017. Analysis of the regimes in the scanner - based laser hardening process, Optics and Lasers in Engineering 90: 72-80.

Matilainen, T., Piili, H., Salminen, A., Nyrhila, O. 2015. Preliminary investigation of keyhole phenomena during single layer fabrication in laser additive manufacturing of stainless steel, Physics procedia 78: 377-387.

Mazumder, J. 2017. 1 - laser - aided direct metal deposition of metals and alloys, Laser additive manufacturing: 21-53.

Merklein, M., Junker, D., Shaub, A., Neubauer, F. 2016. Hybrid additive manufacturing technologies - an analysis regarding potentials and aplications, Physics procedia 83: 549-559.

Mishra, S., Yadava, V. 2015. Laser beam micromachining (LBMM), Optics and lasers in Engineering 73: 89-122.

Murthy, M., Varghese, I., Cetinkaya, I. 2011. Laser cleaning for removal of nano / micro - scale particles and film contamination, Developments in surface contomination and cleaning: 63-122.

Nady, H., Rabiei, M., Samy, M. 2017. Corrosion behavior and electrochemical properties of carbon steel, commercial pure titanium, copper and copper-aliuminum-nickel alloy in 3.5\% sodium chloride containing sulfide ions, Egyptian journal of petroleum 26 (1): 79-94.

Newman, S., Zhu, Z., Dhokia, V., Shorkani, A. 2015. Process planning for additive and subtractive manufacturing technologies, Cirp annals - manufacturing technologies 64: $467-470$. 
Olakanmi, E., Cochrane, R., Dolgarno, K. 2015. A review on selective laser sintering / melting (SLS / SLM) of aluminium alloy powders: Processing, microstructure, and properties, Progress in Materials Science 74: 401-477.

Olejarova, S., Dobransky, J., Svetlik, J., Pituk, M.. 2017. Measurements and evaluation of measurements of vibrations in steel milling process, Measurements 106: 18-25.

Parsian, A., Magnevall, M., Beno, T., Eynian, M. 2017. Sound analysis in drilling, frequency and time domains, Procedia CIRP 58: 411-415.

Paul, R., Anand, S. 2012. Process energy analysis and optimization in selective laser sintering, Journal of manufacturing systems 34 (4): 429-437.

Paulic, M., Irgolic, T., Balic, J., Cus, F., Cupar, A., Brajilih, T., Drstvensek, I. 2014. Reverse Engineering of parts with optical scanning and additive manufacturing, Procedia engineering 69: 795-803.

Purtonen, T., Kalliosaari, A., Salminen, A. 2014. Monitoring and adaptive control of laser processes, Physics procedia 56: 1218-1231.

Ramesh, C., Srinivas, C. 2009. Friction and wear behavior of laser sintered iron - silicon carbide composites, Journal of materials processing technology 209 (14): 5429-5436.

Rodriguez, J., Carbonell, J., Cante, J., Oliver, J. 2017. Continuous chip formation in metal cutting processes using the particle finite element method, International journal of solids structures 120: 1-22.

Romano, J., Ladani, L., Sadowski, M. 2015. Thermal modeling of laser based additive manufacturing processes within common materials, Procedia manufacturing 1: 238250 .

Santos, L., Ferreira, J., Jesus, J., Costa, J., Capela, C. 2016. Fatigue behavior of selective laser melting steel components, Theoritical and applied fracture mechanics 85 (A): 915 .

Schaeffer, R. 2012. Fundamentals of laser micromachining. New York: CRC Press. $260 \mathrm{p}$.

Sedlak, J., Rican, D., Piska, M., Rozkosny, L. 2015. Study of materials produced by powder metallurgy using classical and modern additive laser technology, Procedia Engineering 100: 1232-1241.

Shishkovsky, I. 2015. Laser controlled intermetallics synthesis during surface cladding, Laser surface engineering: 237-286.

Shukla, P., Lawrence, J., Zhang, Y. 2015. Understanding laser beam brightness: A review and new prospective in material processin, Optics and laser technology 75: 40-51.

Silva, B., Kirsch, B., Bottene, A., Simon, A., Aurich,J., Oliveira, J. 2017. Manufacturing of structured surfaces via grindin,. Journal of materials processing technology 243: 170183.

Slide player. [interaktyvus] 2017. [Žiūrèta 2017 m. gegužès 6 d.] Prieiga per internetą: www.slideplayer.pl 
Smolenicki, D., Boos, J., Kuster, F., Wegenar, K. 2012. Analysis of the chip formation of bainitic steel in drilling processes, Procedia CIRP 1: 683-684.

Sovejeva, A., Sallamand, P., Liao, H., Costil, S. 2010. Improvement of flame spraying PEEK coating characteristics using laser, Journal of materials processing technology 211 (1): 12-23.

Sovizi, M., Massudi, R. 2005. Thermal distribution calculation in diode pumped Nd: YAG laser rod by boundary element method, Optics and laser technology 39: 46-52.

Sugioka, K., Cheng, Y. 2013. Ultrafast laser processing. Hardback: Pan Stanford Publishing. $616 \mathrm{p}$.

Torralba, J. 2015. Improvement of mechanical and physical properties in powder metallurgy, Comprehensive materials processing 32 (8): 281-294.

Trenke, D., Muller, N., Rolshofen, W. 2006. Selective laser sintering of metal and ceramic compound structures, Intelligent production machines and systems: 198-203.

Ulkar, E., Lamikiz, A., Lopez de Lacalle, D., Del Pozo, J. A. 2010. Laser polishing of tool steel with $\mathrm{CO} 2$ laser and high - power diode laser, International journal of machine tools and manufacture 50 (1): 115-125.

Ulkar, E., Lamikiz, A., Lopez de Lacalle, L., Martinez, S., Liebana, F. 2010. Thermal model with phase change for process parameter determination in laser surface processing, Physics procedia 5 (B): 395-403.

Valiulis, A. V. 2005. Naujos medžiagos. Vilnius: Technika. 280 p.

Valiulis, A. V. 2008. Welding and thermal cutting. Vilnius: Technika. 292 p.

Vanderesse, N., Gonzalez, I., Nuno, N., Bocher, P. 2016. Image analysis characterization of periodic porous materials produced by additive manufacturing, Materials \& design 92: 767-778.

Venkatesan, K., Ramaujam, R. 2016. Statistical approach for optimization of influencing parameters in laser assisted machining (LAM) of inconel alloy, Measurements 89: 91108.

Vilar, R. 2015. Laser powder deposition. Comprehensive materials processing: 163216.

Wang, D., Yang, Y., Liu, R., Xiao, D., Sun, J. 2013. Study on the designing rules and processability of porous structure based on selective laser melting (SLM), Journal of materials processing technology 213 (10): 1734-1742.

Wang, S., Liao, Z., Liu, Y., Liu W. 2014. Influence of thermal oxidation temperature on the microstructural and tribological behavior of Ti6Al4V alloy, Surface and Coatings Technology 240: 240-477.

Wang, S., Liu, Y., Zhang, C., Liao, Z., Liu, W. 2014. The improvement of wettability, biotribological behavior and corrosion resistance of titanium alloy pretreated by thermal oxidation, Tribology International 79: 174-182. 
Wang, X., Gong, X., Chou, K. 2015. Scanning speed effect on mechanical properties of $\mathrm{Ti}-6 \mathrm{Al}-4 \mathrm{~V}$ alloy processed by electron beam additive manufacturing, Procedia manufacturing 1: 287-295.

Zaeh, M., Ott, M. 2011. Investigations on heat reguliations of additive manufacturing processes for metal structures, CIRP annals - manufacturing technology 60 (1): 259262.

Zhang, Y., Li, S., Chen, G., Mazumder, J. 2012. Experimental observation and simuliation of keyhole dynamics during laser driling, Optics and laser technology 48: 405-414.

Zhang, K., Liu,W., Shang, X. 2007. Research on the processing experiments of laser metal deposition shaping, Optics \& laser technology 39 (3): 549-557.

Zhao, J., Li, Y., Zhang, J., Yu, Ch., Zhang, Y. 2003. Analysis of the wear characteristics of an EDM electrode made by selective laser sintering, Journal of Materials Processing technology 138 (1): 475-478.

Zhu, H., Lu, J., Ni, X., Shen, Z., Zhang, H. 2016. Measurement of thermal energy coupling to metallic meterials in milisecond laser based on optical diffraction, Optics and laser technology 90: 84-89.

Zhu, Y., Zou, J., Chen, X., Yang, H. 2016. Tribology of selective laser melting processed parts: Stainless steel 316L under lubricated conditions, Wear 23: 46-55.

3D maastricht. [interaktyvus] 2017. [Žiūrèta 2017 m. gegužès 3 d.] Prieiga per internetą: www.maastricht.com 


\section{Autoriaus mokslinių publikacijų disertacijos tema sąrašas}

\section{Straipsniai recenzuojamuose mokslo žurnaluose}

Markovič, V., Černašèjus, O., Prokopovič, V. 2013a. Lazerinès miltelių sukepinimo technologijos analizè. Mokslas - Lietuvos ateitis = Science - future of Lithuania: Mechanika, medžiagu inžinerija, pramonès inžinerija ir vadyba = Mechanics, material science, industrial engineering and managemen 5 (6): 676-679, ISSN 2029-2341. (Academic Search Complete; IndexCopernicus)

Markovič, V., Černašejus, O. 2013b. The analysis of laser modification of the surface of sls specimens. Solid state phenomena: Mechatronic Systems and Materials VI. 220-221: 698-702, ISBN 9783038352273. (Scopus; INSPEC)

Vaitkūnaitè, G., Markovič, V., Černašèjus, O. 2014. Selektyviojo lazerinio sukepinimo būdu sukepintų geležies pagrindo miltelių paviršiaus lazerinio mikroapdirbimo tyrimai. Mokslas - Lietuvos Ateitis. 6 (6): 661-665, ISSN 2029-2341. (Gale's Academic OneFile; ProQuest Central; ICONDA)

Markovič, V., Mierzejevska, A., Vaitkūnaitè, V., Indrišiūnas S., Lukauskaite, R., Černašejus, O., Golubev, V. 2016a. Investigation of the laser polishing influence on the part built by sls. Solid state phenomena: Mechatronic Systems and Materials VII 251: 8-13, ISBN 9783035710731. (Scopus; INSPEC) 


\section{Straipsniai kituose leidiniuose}

Černašèjus, O., Markovič, V., Indrišiūnas S., Lukauskaitè, R., Škamat, E. 2015. Лазерная микрообработка спеченных SLS изделий, Proceedings of the international scientific and practical conference "The prospects of using functional coatings", 9th of October, Karaganda state technical university: 51-55, ISBN 9786019177.

Markovič, V., Černašèjus, O., Indrišiūnas, S., Mierzejevska, A., Golubev, V., Lukauskaitè, R., Škamat, E. 2016b. Исследование трибологических свойств SLS спечённых железоникелевых порошков, Новые материалы и технологии: порошковая металлургия, композиционные материалы, защитные покрытия, сварка: материалы 12-й Международной научно-технической конференции, (Минск, 25-27 мая 2016 г.): 209-211, ISBN 9789850820044.

Markovič, V., Černašèjus, O., Indrišiūnas, S., Golubev, V., Lukauskaitè, R., Škamat, E., Višniakov, N. 2016c. Исследование поверхностных слоёв, полученных методом лазерной обработки на образцах, полученных методом селективного лазерного спекания, Современные методы и технологии создания и обработки материалов. Кн. 2 Технологии и оборудование механической и физико-технической обработки: сборник научных трудов, Минск: 283-287, ISBN 9789856441496.

Markovič, V., Černašèjus, O., Škamat, E., Lukauskaitė, R., 2017. Исследование поверхностных слоёв, полученных методом лазерной обработки на образцах, полученных методом селективного лазерного спекания, Proceedings of the International scientific-practical conference "Science and education as a leading factor in strategy Kazakhstan - 2030" (Saginov's readings No. 4), June 28-29, Part 1, Karaganda: Karaganda State Technical University: 34-37, ISBN 978-601-315-291-2. 


\section{Summary in English}

\section{Introduction}

\section{Formulation of the problem}

Recently, a considerable attention is paid to manufacturing advanced and innovative products of geometrically complicated shapes. In most cases, upon striving for improving the performance characteristics of details, assembly units or equipment, it is necessary to form complicated cooling, lubrication or air channel spatial systems inside the details without any violations and changes of the external shape of the product. To achieve the said goal, Selective Laser Sintering technology, or SLS technology, is applied.

SLS technology ensures a high accuracy of the shape of the produced details and reproducibility of the production; however, application of SLS technology for metalware production is limited. Laser sintering of metal powder is a multiplex process that results in a formation of a distinctive structure; the principal peculiarity of the said structure is a system of interconnecting pores of various sizes. During a formation of each layer, hardening of the material from the liquid phase at a high temperature gradient takes place that causes an appearance of considerable residual tensile stresses. The totality of the above-described causes a deterioration of the mechanical and tribological properties, as compared to the traditional moulding. A majority of details manufactured upon applying SLS method are not usable for a long period. Upon unfavourable operating conditions (such as considerable temperature fluctuations, wear, moisture and so on), the service period of sintered products is $2-3$ years only. 
At present, industry needs new innovative methods for processing and modifying the surfaces of sintered products. The opportunities of applying these technologies and the advantages provided by them would improve the performance characteristics of details, assembly units or equipment and reduce the operating expenses.

The offered traditional methods for processing and modifying the sintered surfaces are very expensive and require considerable time input. If the traditional methods are applied for processing the surfaces of the said type, only the geometry of the detail is affected, without a possibility to modify the surface under processing.

\section{The relevance of the thesis}

Recently, the requirements related to environmental pollution caused by industrial equipment, motor vehicles, agricultural equipment and so on are tightened worldwidely. To meet the said requirements, it is necessary to optimize the manufacturing processes and to reduce the costs of repairs. Therefore, at present there is a great need in rapid and economically effective technologies for production as well as for processing and modification of the surface layer of metal.

The idea of the work: to apply a subsequent laser microprocessing for improving the manufacturing technology of products sintered by SLS method and to establish the impact of laser modification of the surface layer on the process of formation of the layer as well as its physical properties and performance characteristics. Final surface modification by laser would enable to avoid the imperfections typical for the ones caused by the traditional SLS technology (such as thermal tensile stresses, large pores, roughness of the surface and large expenses of mechanical processing) and to improve considerably the performance characteristics of the sintered product, as compared to the ones with non-processed surface. A high accuracy laser beam focusing enables to process strictly fixed fragments of a detail and to obtain thin $(0.01-0.3 \mathrm{~mm})$ layers of modified metal. Short duration of the process and precisely dosed energy input will ensure the minimum area of thermal effect and absence of deformations.

The investigation of the process of laser modification of sintered product surface will provide new knowledge about the process of the surface layer formation. The obtained knowledge will enable to optimize the main parameters of a product sintered by pulse laser. This, in its turn, will improve a resistance of such materials to wear and corrosion, reduce their structural and surface inhomogeneity, reduce the prime cost of the product and increase its resource.

\section{The object of the research}

The surface iron-nickel-cobalt based layers formed by selective sintering method and processed by laser microprocessing method.

\section{The aim of the thesis}

To established the impact of laser microprocessing the surface layer of products sintered by SLS method on the layer formation process as well as its physical properties and performance characteristics. 


\section{The tasks of the work}

For an implementation of the aim of the thesis, the following tasks were set:

1. To investigate the impact of technological parameters of laser microprocessing on morphology, topography, physical \& mechanical properties and the chemical composition of SLS sintered layers.

2. To establish the optimum technological parameters of laser microprocessing for ensuring the best performance characteristics of multifunctional surface based on Fe-Ni-Co powder.

\section{The research methodology}

Analytic and experimental research methods were applied in the thesis.

In the work, the impact of rapid laser microprocessing on the formation of the surface layer of products sintered by SLS method as well as its physical properties and performance characteristics was investigated. For the tests, the sintered specimens based on Fe-Ni-Co powder and additionally processed by a concentrated energy source were used. The properties of Fe-Ni-Co powder were examined upon applying scanned electron microscopy, X-ray microanalysis and X-ray diffraction. The microstructure and the phases of the sintered specimens as well as sintered specimens processed by laser beam were examined upon applying the modern material testing methods, such as scanned electron microscopy, X-ray microanalysis and X-ray diffraction. The physical properties and performance characteristics of surfaces of the sintered specimens as well as sintered specimens processed by laser beam were examined by carrying out hardness, wear, corrosion and profilometry tests.

\section{The scientific novelty of the thesis}

Recently, Selective Laser Sintering Technology is widely used in the today works for manufacturing structural parts of complicated shapes. SLS technology is very promising in the sectors of energy facilities, motor vehicles, aircrafts, space exploration, printing engineering, medicine et cetera.

In course of the tests, the optimum parameters of subsequent rapid laser microprocessing the sintered products based on Fe-Ni-Co powder had been established. The tests confirmed that a subsequent laser microprocessing of products sintered by SLS method ensured a formation of a new surface layer of the sintered metal (of higher density and modified) with a better topography of the surface and improved hardness and wear resistance. In course of preparation of the Thesis, the following results innovative for material engineering science were obtained:

1. An application of subsequent laser microprocessing technology of products (based on Fe-Ni-Co powder) sintered by SLS method enabled to create the multifunctional layer on the surface of the sintered specimen that distinguishes for improved performance characteristics.

2. The established correlation between the morphology, topography, phase composition as well as mechanical, tribological and anti-corrosive properties of the surface of specimens sintered by SLS method and processed by a nanosecond laser with the laser treating process and its parameters enables cho- 
osing the optimum parameters of the processing mode for specific operating conditions.

\section{The practical value of the research finding}

An application of subsequent laser microprocessing technology of products (based on Fe-Ni-Co powder) sintered by SLS method could be applied in the industry fields where very important products with sophisticated shape are used widely (plastic injection tools, parts of the engines and turbines etc.).

\section{The defended statement}

A high accuracy of subsequent laser microprocessing the specimens sintered by SLS method, with precisely dosed energy input and a short duration of the processed layer formation cause a formation of a new modified surface layer of the sintered metal and ensure a better topography of the surface as well as improved hardness and wear resistance.

\section{Approval of the research findings}

Total 8 scientific papers on the subject of the Thesis have been published: 4 papers were published in scientific journals reviewed in international databases and 4 papers - in reviewed scientific publications.

The results of the research described in the Thesis were presented at ten scientific conferences in Lithuania and abroad:

- at the Conferences of Young Scientists "Science - the Future of Lithuania" held in the years 2011 and 2014 in Vilnius;

- at the International Conference "Mechatronic Systems and Materials" held in 2013 in Vilnius and in 2015 in Kaunas;

- at the International Conference "Advanced Materials and Technologies" held in 2013 in Palanga;

- at the International Conference "The Prospects of Using Functional Coatings" held in 2015 in Karaganda;

- at the International Conference "New Materials and Technologies: Powder Metallurgy, Composite Materials, Protective Coatings, Welding” held in 2016 in Minsk;

- at the International Conference "Modern Methods and Technologies for Creation and Processing of Materials" held in 2015 and 2016 in Minsk;

- at the International Conference "Science Integration, Education and Production - Basis of the Implementation of the Plan of the Nation: Saginov's Readings № 9" held in 2017 in Karaganda.

\section{The structure of the thesis}

The thesis includes the introduction, three chapters and the general conclusion. In addition, five annexes are enclosed.

The thesis consists of 106 pages, except of those of the Annex; in the text, 6 numbered formulas, 53 Figures and 13 Tables are provided. In course of preparation of the Thesis, 109 sources of the literature were used. 


\section{The peculiarity analysis of the additive manufacturing and modification of the metalic surfaces}

Additive manufacturing (AM) enables to produce details, assembly units or equipment of particularly complicated geometric shapes and to implement complex technological solutions. Selective Laser Sintering technology, or SLS technology, is a process included in the group of AM technologies.

Metal powder sintering by laser is a multiplex process that results in a formation of a distinctive structure; the principal peculiarity of the said structure is a system of interconnecting pores of various sizes. In course of melting of metal powder particles, pores and cavities up to $100 \mu \mathrm{m}$ are formed in the material upon action of the thermocapillary forces. During a formation of each layer, hardening of the material from the liquid phase at a high temperature gradient takes place that causes an appearance of considerable residual tensile stresses. The totality of the above-described causes a deterioration of the mechanical and tribological properties, as compared to the traditional moulding. For this reason, formation of metal products upon applying SLS method is limited.

Microprocessing of surfaces of sintered products by a laser beam is one of the methods for tackling the problems caused by Selective Laser Sintering. The duration of the interaction between the laser beam and the surface under processing is a very important parameter that predetermines the impact of the laser beam on the material. While analyzing the interaction between the laser beam and solid bodies, the principal optical phenomena important for laser processing of surfaces should be taken into consideration. During laser processing, the absorption and reflection of laser radiation vary dynamically, so thoroughful investigation of the dependence of the properties of the material under processing on the changes of the parameters of the laser beam is required to ensure a good result of processing the engineering material.

The most important property of lasers used in processing of materials is a possibility to achieve very high intensity of radiation in a chosen point of the surface under processing that is hard to achieve upon applying another processing methods. Upon varying the energy input, it is possible to create different laser processing methods based of different physical processes, such as heating, melting, ablation or evaporation.

A subsequent processing of sintered surface by a source of concentrated energy will ensure much better physical and mechanical properties of the surface layer, as compared to the traditional processing methods; in addition, it will improve other characteristics of the processed surfaces as well. This will enable to increase the resource of sintered products and to save energy and materials. So, it is purposeful to investigate laser sintering with a subsequent laser processing in order to assess the efficiency and benefits of the newly created process.

\section{Materials used and methods of investigation of the sintered surface based on iron-nickel-cobalt powder}

For a formation of the sintered volume, Fe-Ni-Co powder was used as a base. The steel grade was chosen upon taking into account very broad opportunities of use of the material in production of polymer casting equipment. 


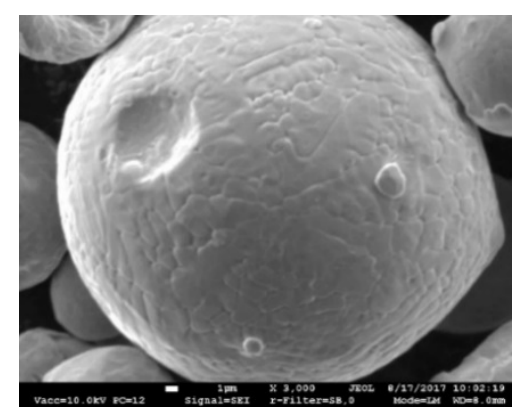

a)

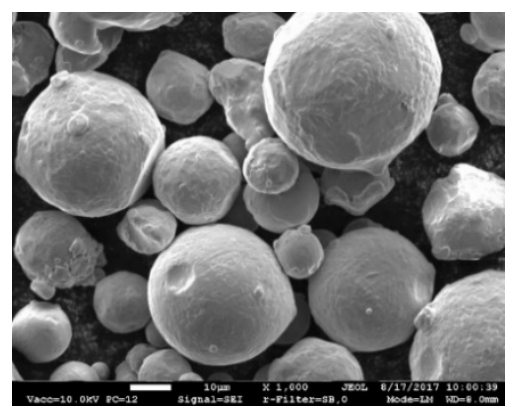

b)

Fig. S2.1. Morphology of the powder usable for sintering

The analysis of the powder for selective laser sintering showed that the size of their fractions varies between 7 and $30 \mu \mathrm{m}$. Particles of the powder are of irregular geometric shapes (Fig. S2.1). On the surface of the particles, a dendrite primary crystallization structure can be seen (Fig. S2.1, a). A part of the powder particles is presented by formations consisting of a large particle and several small fractions adhered to it (Fig. S2.1, b).

For production of the powder-based specimens, selective laser sintering equipment Concept Laser M3 was used.

For separation of the sintered volume from the substrate, the wire spark erosion machine Charmille cut 200 was used. The specimens separated from the substrate were cleaned in an ultrasonic bath filled with $\mathrm{C}_{3} \mathrm{H}_{8} \mathrm{O}$ solution. The duration of cleaning was 15 minutes. The temperature of the cleaning medium was $40^{\circ} \mathrm{C}$.

In course of microscopic tests of the sintered specimens, it was found that top and lateral surfaces of the specimens distinguished for absolutely different morphologies of the surface layer. In case of a lateral surface, irregularly and chaotically distributed bumps can be seen (Fig. S2.2, a). Whereas in case of the top surface, a regularly formed facture (Fig. S2.2, b) can be seen. This essential difference is caused by the technological peculiarities of selective laser sintering process.

For laser microprocessing the sintered specimens, a nanosecond pulse laser Baltic HP was chosen. The sintered workpiece, separated from the substrate by the wire spark erosion machine Charmille cut 200, was divided to specimens of the same size $(10 \times 10 \times 10 \mathrm{~mm})$.

The experimental tests of laser microprocessing of sintered surfaces were divided to four essential phases:

The experiment A - a partial processing of the top surface polished to $R_{a}=0.2 \mu \mathrm{m}$ while pushing a specimen in the only direction. The power $\mathrm{P}$ of the laser was varied from 1 to $4 \mathrm{~W}$, the processing speed $v$ - from 1 to $7.5 \mathrm{~mm} / \mathrm{s}$, the number of passes $n$ was 1. 


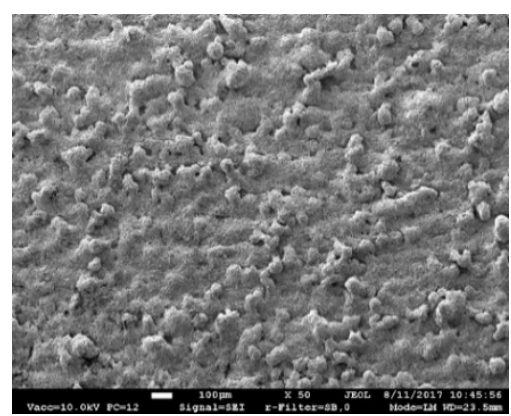

a)

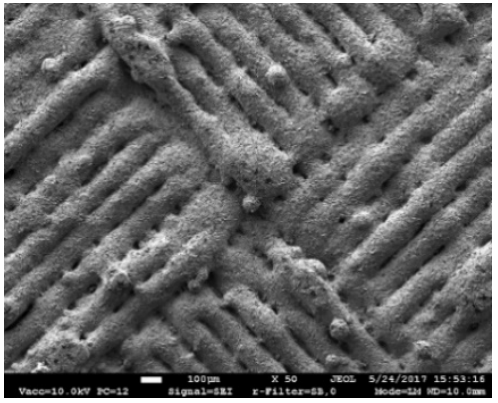

b)

Fig. S2.2. The topography of sintered specimens: a) the lateral surface of a sintered specimen; b) the top surface of the sintered specimen

The experiment $\mathrm{B}$ - a complete processing of the top surface polished to $R_{a}=0.2$ $\mu \mathrm{m}$ while pushing a specimen in two directions. The power $\mathrm{P}$ of the laser was $2.5 \mathrm{~W}$, the processing speed $v-2.5 \mathrm{~mm} / \mathrm{s}$, the number of passes $n$ was varied from 1 to 4 .

The experiment $\mathrm{C}-$ a complete processing of a sintered lateral surface while pushing a specimen in two directions. The power $\mathrm{P}$ of the laser was varied from 2 to $3 \mathrm{~W}$, the processing speed $v$ - from 1 to $5 \mathrm{~mm} / \mathrm{s}$, the number of passes $n$ - from 1 to 6 (Table S2.1).

The experiment $\mathrm{D}$ - a complete processing of the sintered top surface while pushing a specimen in two directions. The power $P$ of the laser was varied from 2 to $3.5 \mathrm{~W}$, the processing speed $v-$ from 1 to $5 \mathrm{~mm} / \mathrm{s}$, the number of passes $n$ - from 1 to 4 (Table $\mathrm{S} 2.2)$.

Table S2.1. The technological parameters of laser processing in the experiment C

\begin{tabular}{|c|c|c|c|c|}
\hline \multirow{2}{*}{$\begin{array}{c}\text { The mark of a } \\
\text { specimen }\end{array}$} & \multicolumn{3}{|c|}{ A processing parameter } & The level of \\
\cline { 2 - 4 } & Power $P, \mathrm{~W}$ & $\begin{array}{c}\text { Processing } \\
\text { speed v, mm/s }\end{array}$ & $\begin{array}{c}\text { Number of } \\
\text { passes } n\end{array}$ & E3 \\
\hline $\mathrm{C} 1$ & 2 & 1 & 1 & E2 \\
\hline $\mathrm{C} 2$ & 2 & 2.5 & 1 & E1 \\
\hline $\mathrm{C} 3$ & 2 & 5 & 1 & E3 \\
\hline $\mathrm{C} 4$ & 2.5 & 1 & 1 & E2 \\
\hline $\mathrm{C} 5$ & 2.5 & 2.5 & 1 & E1 \\
\hline C6 & 2.5 & 5 & 1 & E3 \\
\hline C7 & 3 & 1 & 1 & E1 \\
\hline C8 & 3 & 2.5 & 1 & E2 \\
\hline C9 & 3 & 5 & 2 & E2 \\
\hline C10 & 2.5 & 2.5 & 4 & E2 \\
\hline C12 & 2.5 & 2.5 & 6 & \\
\hline
\end{tabular}

In laser microprocessing, a very important role is played by energy input E provided to area $\mathrm{S}$ within time period t. For systematization of the technological parameters of 
laser microprocessing, the energy input levels were calculated and distributed in the work.

Table S2.2. The technological parameters of laser processing in the experiment D

\begin{tabular}{|c|c|c|c|c|}
\hline \multirow{2}{*}{$\begin{array}{c}\text { The mark of a } \\
\text { specimen }\end{array}$} & \multicolumn{3}{|c|}{ A processing parameter } & \multirow{2}{*}{$\begin{array}{c}\text { The level of } \\
\text { energy input }\end{array}$} \\
\cline { 2 - 4 } & Power $P, \mathrm{~W}$ & $\begin{array}{c}\text { Processing } \\
\text { speed } v, \mathrm{~mm} / \mathrm{s}\end{array}$ & $\begin{array}{c}\text { Number of } \\
\text { passes } n\end{array}$ & E3 \\
\hline D1 & 2 & 1 & 1 & E2 \\
\hline D2 & 2 & 2.5 & 1 & E1 \\
\hline D3 & 2.5 & 5 & 1 & E3 \\
\hline D4 & 2.5 & 2.5 & 1 & E2 \\
\hline D5 & 2.5 & 5 & 1 & E1 \\
\hline D6 & 3 & 1 & 1 & E3 \\
\hline D7 & 3 & 2.5 & 1 & E1 \\
\hline D8 & 3.5 & 5 & 1 & E3 \\
\hline D9 & 3.5 & 2.5 & 1 & E2 \\
\hline D10 & 3.5 & 5 & 1 & E1 \\
\hline D11 & 2.5 & 2.5 & 2 & E2 \\
\hline D12 & 2.5 & 2.5 & 4 & E2 \\
\hline D13 & & 1 & 1 & 1 \\
\hline D14 & & & & 1 \\
\hline
\end{tabular}

In the work, complex research of a sintered surface processed by a concentrated energy source has been completed. During the research, the macro- and the microstructure of the sintered surface processed by a concentrated energy source as well as its chemical composition were analyzed. The microhardness and microroughness tests of the surface layer of the experimental specimens have been performed. The tribological properties of the surfaces have been explored. The corrosion tests have been carried out as well.

The morphology of sintered specimens processed by a concentrated energy source has been examined upon using scanned electron microscopy device SEM JEOL JSM-7600F with SE detector of secondary electrons. The parameters of electron microscopy are following: the accelerating voltage $10 \mathrm{kV}$, the distance to the surface of the specimen $11 \mathrm{~mm}$, the magnification from 50 to 1000 times, temperature $22{ }^{\circ} \mathrm{C}$. The surfaces of sintered specimens after laser processing were analyzed by SEM method upon using the stream of secondary electrons. Surfaces of the specimens were cleaned with $\mathrm{C}_{3} \mathrm{H}_{8} \mathrm{O}$ solution. In addition, the chemical composition of the raw material (the powder) and the experimental specimens were analyzed upon applying the method of X-ray microanalysis.

The qualitative analysis of phase composition of sintered specimens after laser processing by a concentrated energy source was carried out by X-ray diffractometer SMART LAB (Japan). For separation of the X-ray radiation, a graphite monochromator was used. The parameters of the tests were following: the voltage $9 \mathrm{kV}$, the diffraction angle $2 \theta$ range from 20 to $80^{\circ}$, the step of detector movement $-0.02^{\circ}$. The diffractogram was recorded at a speed of $1 \%$ minute. The test was performed at the 
temperature of $22{ }^{\circ} \mathrm{C}$. The tests were carried out with specimens based on $\mathrm{Fe}-\mathrm{Ni}-\mathrm{Co}$ powder that were sintered and additionally polished and processed by laser beam. All the results of the analysis are provided as diffraction curves that show the dependence of the intensity of the reflected X-rays on the detector's angle.

The parameters of the surface microroughness of the sintered specimens after their processing by a concentrated energy source were established using the portable profilometer TR-200 with measuring accuracy $\pm 0.01 \mu \mathrm{m}$.

The microhardness of sintered specimens after their processing by a concentrated energy source was assessed in polished microsections using the versatile automated hardness meter Zwick Roell $Z H \mu$ with $1 \%$ measurement error. The measurements were carried out by Vickers hardness test at the load of $100 \mathrm{~g}$ and the exposure time of $10 \mathrm{~s}$ at the optical magnification of 50 times. The average microhardness of the surface layer of the sintered specimen after its processing by a concentrated energy source was calculated on the base of results of 10 measurements, upon rejection of the maximum and the minimum values.

The friction resistance of sintered specimens under investigation after their processing by a concentrated energy source in the experiment $\mathrm{C}$ was assessed on the dry friction test. In the experiment $C$, it was carried out by Microtest tribometer upon the following modes of the experiment: the sliding distance $-200 \mathrm{~m}$, the sliding speed $300 \mathrm{rpm}$, the radius of the trajectory $-2 \mathrm{~mm}$, the load $-5 \mathrm{~N}$, the temperature of the test $-23{ }^{\circ} \mathrm{C}$. For the experimental test, "Pin-on-disc" friction scheme was chosen. The indentor was a $3 \mathrm{~mm}$ diameter tempered cylinder made of stainless steel 1.4034.

The friction resistance of sintered specimens after their processing by a concentrated energy source in the experiment D was assessed on the dry friction test using Microtest tribometer upon applying the following modes: the sliding distance -400 $\mathrm{m}$, the sliding speed $-300 \mathrm{rpm}$, the radius of the trajectory $-2 \mathrm{~mm}$, the load $-5 \mathrm{~N}$, the temperature of the test $-23{ }^{\circ} \mathrm{C}$. For the experimental test, "Ball-on-disc" friction scheme was chosen. The indentor was a $6 \mathrm{~mm}$ diameter tempered ball (usable in bearings) made of stainless steel AISI52100.

The corrosion resistance of sintered specimens after their processing by a concentrated energy source was assessed by measurements of potentiodynamic polarization. The experimental tests were carried out using the electrochemical measurement system SOLARTON 1280C (United Kingdom). It consists of a potentiostat, a galvanostat, a frequency generator and an impedance spectrum analyzer. The measurements were carried out upon using a 3-electrode electrochemical cell. A platinum wire was used as an auxiliary electrode and the reference electrode was $\mathrm{Ag} / \mathrm{AgCl} / \mathrm{KCl}$. The corrosion resistance tests were carried out in $0.5 \mathrm{M} \mathrm{Na}_{2} \mathrm{SO}_{4}$ medium. Electrochemical measurements were carried out after 60 minutes, when the corrosion potential was settled by spreading the potential towards the anode and the cathode. The potential spreading speed was $10 \mathrm{mV} / \mathrm{s}$. The electrochemical parameters, such as the corrosion potential (Ekor.) and corrosion current (j), were researched upon applying the relevant data processing software. 


\section{The investigation of the process of modifaying the surface of sintered specimens based on powder by a concentrated energy source and the performance characteristics of the specimens}

In the Chapter, an analysis of characteristics of sintered specimens subsequently processed by a concentrated energy source is provided. In addition, the impact of the laser beam technological parameters on the morphology, profilometry, chemical and phase composition as well as the performance characteristics and mechanical properties of the surface under processing is described.

In course of the microscopic test, it was found that the average roughness of a sintered non-processed lateral surface was $R_{a}=9.2 \mu \mathrm{m}$, whereas the roughness of the top surface was $R_{a}=17.9 \mu \mathrm{m}$. The difference is caused by the technological peculiarities of the selective laser sintering process.

In course of the tests on morphology and topography of lateral surfaces of specimens sintered according to SLS technology and subsequently passed microprocessing by laser, three essential factures of the surface were formed, including: porous and insufficiently melted; irregularly vaporised with chaotically distributed bumps and; uniformly and targetedly vaporised. When the lateral sintered surface is processed in a single pass (the specimen C5), the average height of microroughness was reduced by $50 \%$, as compared to the sintered specimen without a subsequent processing (Fig. S3.1). An increase of the number of laser microprocessing passes from 1 to 2 (the specimen C5), caused no noticeable impact on the indicators of the profilometry of the surface and the average value of the roughness remained almost the same $\left(R_{a}=5.4 \mu \mathrm{m}\right)$. When the number of passes was increased to 4 , the decrease of the roughness down to $R_{a}=4.27 \mu \mathrm{m}$ was observed on the surface of the specimen. The change of the roughness, when the number of passes is increased from 1 to 4, is predetermined by additional vaporisation of the tops of surface microroughnesses.

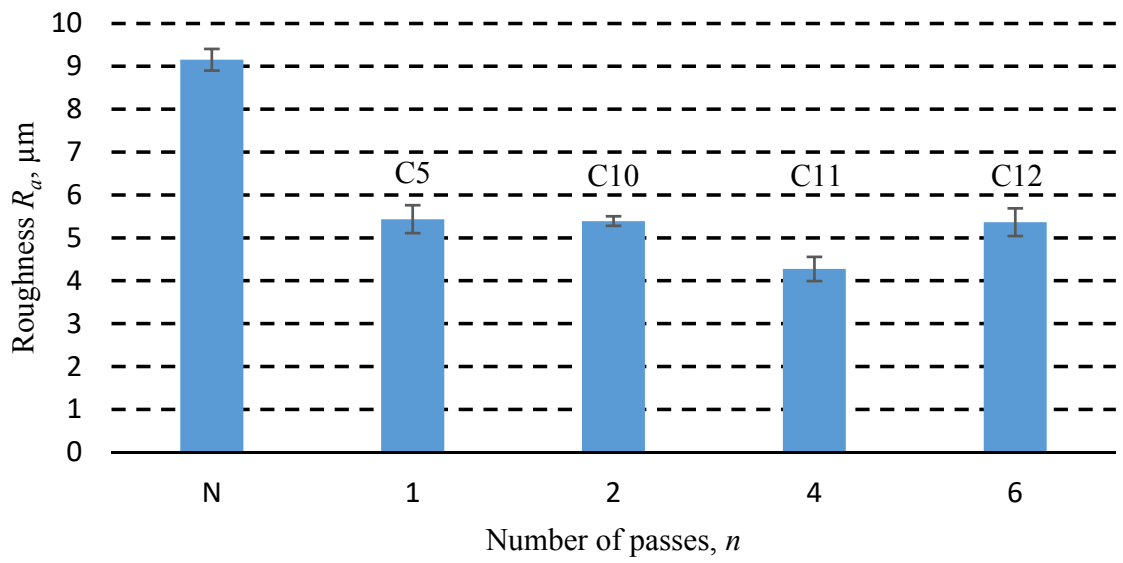

Fig. S3.1. The dependence of the roughness of specimens on the laser processing speed at different processing powers in the experiment $\mathrm{C}$ 
When the number of passes is further increased up to 6 (the specimen C12), cracks are formed on the surface of the specimen and the average height of microroughnesses increases to $5.37 \mu \mathrm{m}$. It is predetermined by the metal surface overheating and changes of thermal processes.

When the top sintered surface was processed in a single pass at the stream power $P=2.5 \mathrm{~W}$ and the processing speed of $2.5 \mathrm{~mm} / \mathrm{s}$, the average height of microroughnesses deceased by about $60 \%$ (the specimen D5). The increase of the number of passes to 2 causes a negative impact on the roughness of the surface: the roughness of surface of sintered and subsequently laser-processed specimens doubles, i.e. increases from $R_{a}=$ $6.22 \mu \mathrm{m}$ (the specimen D5) to $R_{a}=12.17 \mu \mathrm{m}$ (D13). The increase of the number of passes of laser microprocessing to 4 causes a further increase of the roughness up to $R_{a}=$ $18.41 \mu \mathrm{m}$ (the specimen D14). The increase of roughness is predetermined by overheating of the processed surface and formation of cracks on the surface.

During the microhardness test in the experiment $\mathrm{C}$, it was found that the microhardness of sintered and laser processed layer increases at a transfer from the energy level E1 to the energy level E3 when laser processing speed is reduced and the laser power is increased. The maximum difference between the values of microhardness of specimens processed at power of $2-3 \mathrm{~W}$ is up to $10 \%$. The difference between hardnesses of unprocessed specimen (297 HV) and laser-processed specimens achieves up to $88 \%$. The maximum value of hardness of laser processed specimens is $558 \mathrm{HV}$ (the specimen D10) achieved at the energy input level E3, when $P=3.5 \mathrm{~W}, V=1 \mathrm{~mm} / \mathrm{s}$ and while working in a single pass processing mode.

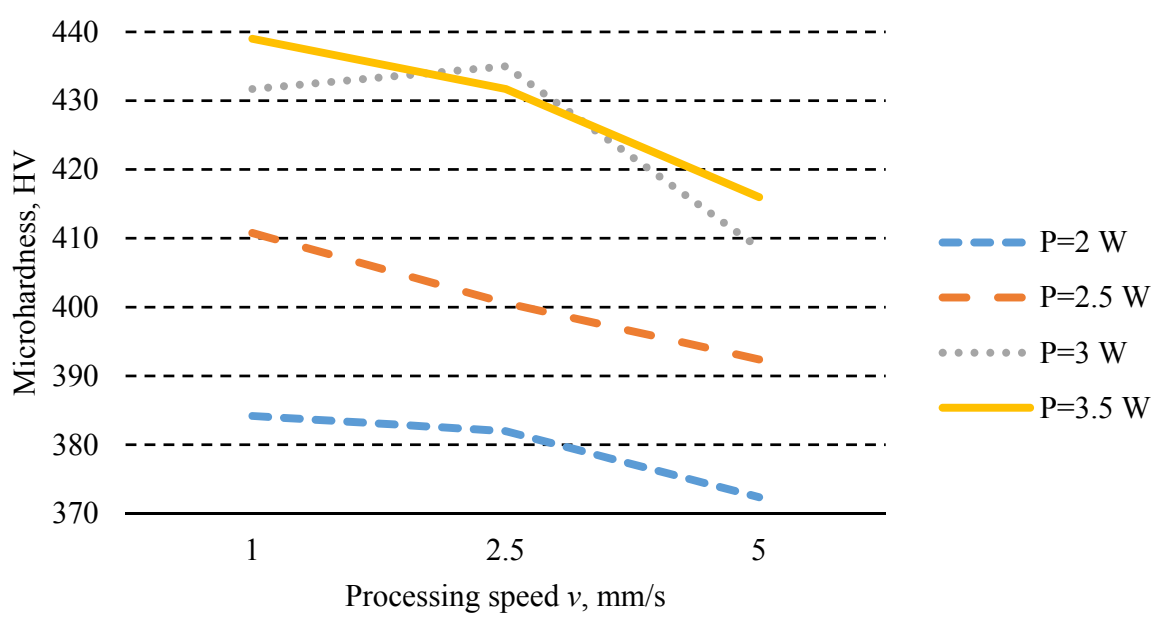

Fig. S3.2. The dependence of the microhardness of specimens on the laser processing speed at different values of processing power in the experiment $\mathrm{D}$

During the microhardness test in the experiment D (Fig. S3.2), it was found that on increase of energy input in laser processing (transfer from the energy input level E1 to 
the energy input level E3), the microhardness of sintered and laser processed layer increases both in the cases of the experiment $\mathrm{C}$ and the experiment $\mathrm{D}$.

While comparing the hardness of unprocessed specimen $(297 \mathrm{HV})$ and a laser processed specimen, the difference achieves $48 \%$ (experiment D). The maximum value of microhardness, i.e. $439 \mathrm{HV}$ (the specimen D10), is obtained at the laser processing energy input level E3, when $P=3.5 \mathrm{~W}, V=1 \mathrm{~mm} / \mathrm{s}$ at the number of passes equal to one. The maximum difference between the values of microhardness of specimens processed by power 2 and power $2.5 \mathrm{~W}$ was $10.5 \%$ and the maximum difference between the values of microhardness of specimens processed by power 2.5 and power $3 \mathrm{~W}$ was $12 \%$. Further increasing the power of laser processing does not provide a positive impact on the microhardness of sintered and laser processed metal and the maximum difference between the values of microhardness of specimens processed by powers 3 and 3,5 W is only $1.6 \%$ even at the maximum processing speed. This shows that increasing the power of laser processing does not cause a considerable impact on the microstructure of the processed metal as well as its phasic and chemical composition.

During the investigation, it was found that increasing the number of laser microprocessing passes practically caused no impact on the indicators of the microhardness of the sintered material. An analogous dependence was observed both in the cases of the experiment $\mathrm{C}$ and the experiment $\mathrm{D}$.

During the wear resistance tests in the experiment $\mathrm{C}$, it was found that the unprocessed specimen's lateral surface mass loss achieved $2270 \mu \mathrm{g}$. In course of the experiment, it was established that on processing the sintered lateral surface by laser radiation, the following general trend took place: the minimum mass losses (when the number or passes $n=1$ ) were observed at the laser processing energy level E3. It was predetermined by increasing the heat input, when the processing speed reduced from 5 to 1 $\mathrm{mm} / \mathrm{s}$, and the maximum microhardness of metal surface.

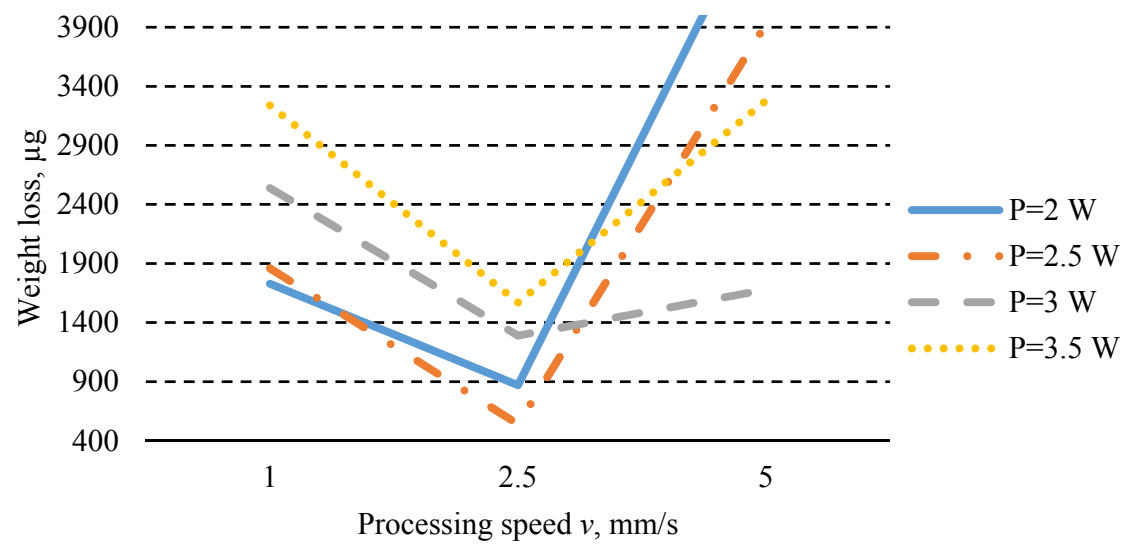

Fig. S3.3. The results of specimen wear resistance tests in the experiment D

The minimum specimen mass loss $(180 \mu \mathrm{g})$ in the experiment $\mathrm{C}$ (the specimen C11) took place at the energy input level E2 (when $P=2.5 \mathrm{~W}$ and $V=2.5 \mathrm{~mm} / \mathrm{s}$ ) and the 
number of passes equal to four. In such a case, the minimum mass loss was predetermined by the minimum value of the average height of microroughness of the specimen C11 surface, i.e. $R_{a}=4.27 \mu \mathrm{m}$. The additional laser processing of the sintered surface, when the number of passes $n$ was increased from 2 to 4 , reduces the values of surface microroughness of specimens from the series $\mathrm{C}$ and this positively affects the mass loss indicators of the specimen.

During the wear resistance test in the experiment $\mathrm{D}$, it was found that the unprocessed specimen's top surface mass loss achieved $9070 \mu \mathrm{g}$. The results of the test showed (Fig. S3.3) that at the laser processing power from 2 to $3.5 \mathrm{~W}$ and the processing speed $\mathrm{V}=1 \mathrm{~mm} / \mathrm{s}$, the mass loss of laser processed surface was from 1730 to $3240 \mu \mathrm{g}$ (the specimens D1-D4).

Increasing the laser microprocessing speed up to $2.5 \mathrm{~mm} / \mathrm{s}$ (the energy input level E2) ensured the minimum mass loss of laser processed surface, i.e. from 540 to $1570 \mu \mathrm{g}$ (specimens D5-D8). It was predetermined by the less height of microroughness of specimen surface processed at the speed of $2.5 \mathrm{~mm} / \mathrm{s}$. Further increasing the speed of laser processing to $V=5 \mathrm{~mm} / \mathrm{s}$ caused an increase of mass loss of specimens from the series D that became from 1860 to $3930 \mu \mathrm{g}$ (the specimens D9-D12). The maximum mass loss was observed in specimens processed by the speed of $5 \mathrm{~mm} / \mathrm{s}$ (the energy input level E1); it was predetermined by the minimum microhardness of the specimens D3, D6, D9 and D12 and the maximum roughness of them. The mass loss of laser processed specimens of the series D directly correlates with the results of the surface profilometry tests. When sintered top surface is processed by laser radiation, the minimum mass loss 540 $\mu \mathrm{g}$ (the specimen D5) is observed at the energy input level E2, when $P=2.5 \mathrm{~W} ; V=2.5$ $\mathrm{mm} / \mathrm{s}$ (Fig. S3.3).

During the tribological test in the experiment $\mathrm{C}$, it was found that the arithmetic mean of friction coefficient of the unprocessed lateral surface is equal to 0.94 . After laser microprocessing of the sintered lateral surface (when $P=2.5 \mathrm{~W}$ and $V=2.5 \mathrm{~mm} / \mathrm{s}$ ), upon the number of passes not exceeding 2 (the specimens $\mathrm{C} 5$ and $\mathrm{C} 10$ ), the value of friction coefficient was 0.46 and 0.54 respectively. The difference between the unprocessed sintered surfaces and the ones having passed laser processing was predetermined by the peculiarities of the topography of the surface (sintered by SLS) and possibly formed intermetallic compounds in the top layer of the processed specimen. On increasing the number of laser processing passes to 4 , the minimum value of the arithmetic mean of friction coefficient (0.35) was obtained (the specimen C11). It was predetermined by the minimum roughness of the laser processed surface of the specimen $\mathrm{C} 11$.

During the tribological test in the experiment $\mathrm{D}$, it was found that the arithmetic mean of friction coefficient of the unprocessed top surface is equal to 1.05 . It was predetermined by extraordinary high roughness of the unprocessed top surface $\left(R_{a}=17.9 \mu \mathrm{m}\right)$. Whereas the value of friction coefficient of the sintered top surface after laser microprocessing in a single pass, when $P=2.5 \mathrm{~W}$ and $V=2.5 \mathrm{~mm} / \mathrm{s}$ (the specimen D5) is 0.95 . The difference between the unprocessed sintered surfaces and the ones having passed laser processing was predetermined by the peculiarities of the topography of the surface (sintered by SLS), high microhardness and low roughness of the laser processed surface $R_{a}=6.22 \mu \mathrm{m}$ (the specimen $\mathrm{D} 5$ ). The minimum value of the arithmetic mean of friction coefficient (0.81) was obtained (the specimen D10) at the power of $3.5 \mathrm{~W}$ and the pro- 
cessing speed of $1 \mathrm{~mm} / \mathrm{s}$. It was predetermined by the maximum (439 HV) microhardness of the laser processed surface (the specimen D10). In course of the investigation, it was found that the values of friction coefficient correlate with the values of microhardness of the top surface of the specimens D5 and D10, i.e. $279 \mathrm{HV}, 401 \mathrm{HV}$ and $439 \mathrm{HV}$, respectively.

During the tribology and wear resistance test, it was found that on laser microprocessing of sintered specimen, the friction coefficient of the top and lateral metal surface decreased by $19 \%$ and $63 \%$, respectively; and the rate of wear of laser processed metal surface layer - 17 and 39 times, respectively.

During the phasic analysis of sintered (by SLS) and unprocessed surface of the specimen, it was found that the structure of the surface metal layer under investigation consists of a martensitic structure with cubic centered volume grating (lattice) and residual austenite.

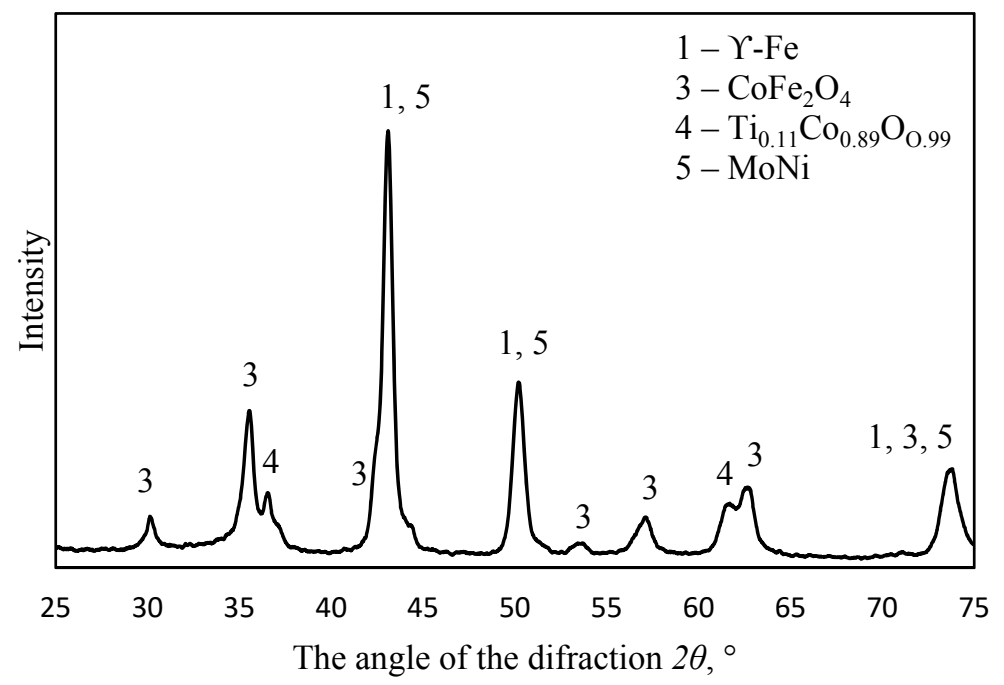

Fig. S3.4. The curve of X-ray diffraction of laser processed specimen D5

On the base of analysis of the diffraction curve (Fig. S3.4), it was found that the laser radiation caused a formation of an intermetallic compound of residual austenite and molybdenum/nickel as well as oxides, such as cobalt iron oxide $\mathrm{CoFe} 2 \mathrm{O} 4$, titanium cobalt oxide Ti0.11Co0.8900.99 and iron oxide $\mathrm{Fe}_{3} \mathrm{O}_{4}$, on the surface of the specimens under investigation. Increasing the speed of laser microprocessing causes a reduction of the concentration of solid metal oxides (Fig. S3.5). It is bound with a lower temperature of the laser processed surface, a shorter exposure time and the oxidation processes on the metal surface. The established dependence correlates with the changes of microhardness of surfaces sintered by SLS and processed by laser caused by increasing the speed of processing. Increasing the laser microprocessing speed from $1 \mathrm{~mm} / \mathrm{s}$ to $5 \mathrm{~mm} / \mathrm{s}$ at the 
power of $2.5 \mathrm{~W}$ causes a reduction of concentration of solid metal oxides from $70 \%$ to $36 \%$ (Fig. S3.5). An analogous change of the speed of laser microprocessing at the power of $3 \mathrm{~W}$ causes a reduction of concentration of solid metal oxides from $68 \%$ to $37 \%$.

While examining the microstructure of sintered and laser processed specimens, it was found that because of specific heat input (typical for laser processing), the microstructure of the sintered products was not perfect. It consists of chaotically distributed oblong needle-shaped grains. The dark fragments visible in the microstructure are the traces of residual austenite and admixtures.

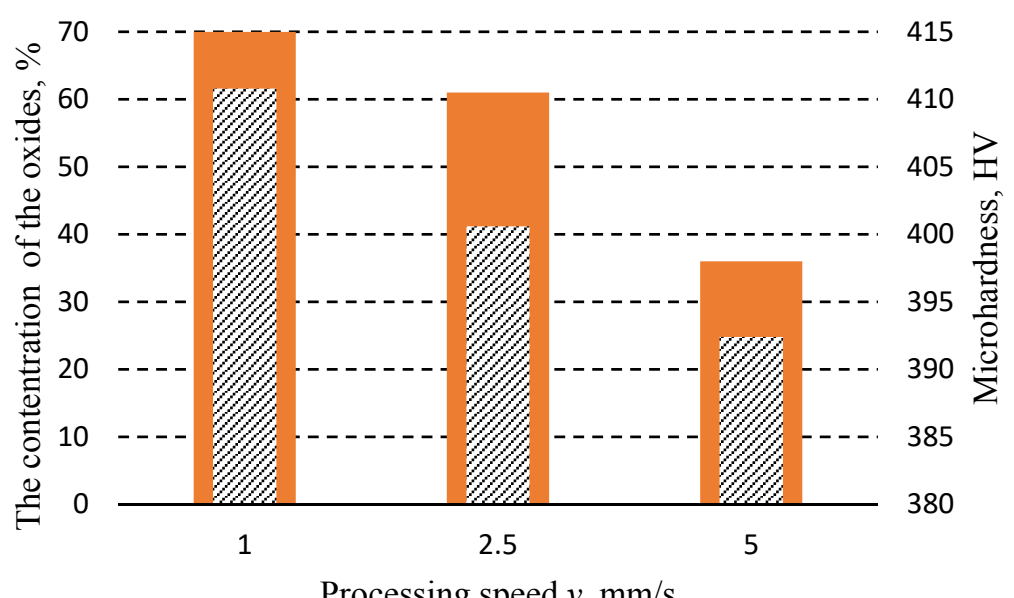

Processing speed $v, \mathrm{~mm} / \mathrm{s}$

The concentration of the hard oxides, \% $\not$ Microhardness, HV

Fig. S3.5. The dependence of the hardness of specimens sintered by SLS method and having passed a subsequent laser microprocessing on the concentration of solid metal oxides at different processing speeds

The microstructure of the surface layer of sintered specimen subsequently having passed laser microprocessing is very similar to the microstructure on the unprocessed specimen. The similarity of the structures also attests the minimum residual tensions on the surface of sintered and subsequently laser processed specimen. It was found that the microstructure of the laser processed surface consisted of chaotically distributed oblong needle-shaped grains. The peripheral areas of the grains distinguish for distinctive rugged facture possibly formed by the residual austenite in the grains.

The electrochemical corrosion analysis of the specimens sintered by SLS and subsequently processed by laser radiation provides a basis for stating that laser does not cause a negative impact on corrosive resistance of the sintered surface. 


\section{General conclusions}

1. The technology of subsequent laser microprocessing of products on the base of Fe-Ni-Co powder sintered by SLS method enables to modify the sintered metal. The impact of laser microprocessing (the power of the laser beam, processing speed and a number of passes) of the metal surface layer of the sintered products (based on Fe-Ni-Co powder) on the layer formation process as well as its physical properties (microhardess, wear speed, surface roughness, corrosion resistance etc.) and performance had been established.

2. The morphology of the surface of products on the base of Fe-Ni-Co powder sintered by SLS and having passed subsequent laser microprocessing depends on the level of input energy in laser processing. While laser microprocessing at $V=2.5 \mathrm{~mm} / \mathrm{s}$ and $P=2.5 \mathrm{~W}$, the roughness parameter $R_{a}$ for the lateral and the top surface (vertical and horizontal surface) reduced by $54 \%$ and $65 \%$, respectively was equal to $R_{a}=4.27 \mu \mathrm{m}$ and $R_{a}=6.22 \mu \mathrm{m}$, respectively.

3. The hardness of the surface of products on the base of Fe-Ni-Co powder sintered by SLS method and having passed subsequent laser microprocessing depends on the concentration of solid oxides $\mathrm{CoFe}_{2} \mathrm{O}_{4}$ and $\mathrm{Ti}_{0.11} \mathrm{Co}_{0.89} \mathrm{O}_{0.99}$ formed in the top metal layer during laser processing. When the concentration of solid oxides increases, the microhardness of the top metal layer grows. At the concentration of solid oxides $\approx 70 \%(P=2.5 \mathrm{~W} ; V=2.5 \mathrm{~mm} / \mathrm{s})$, the microhardness of sintered surfaces after laser processing increased by $88 \%$ and $48 \%$, as compared to unprocessed surfaces and was equal to $558 \mathrm{HV}$ and $439 \mathrm{HV}$, respectively.

4. The rate of wear of the surface of products on the base of Fe-Ni-Co powder sintered by SLS and having passed subsequent laser microprocessing is predetermined by a complex change of microhardness and morphology of top metal layer after laser processing. The increased microhardness of the lateral (from $71 \%$ to $88 \%$ ) and the top (from $25 \%$ to $48 \%$ ) surface as well as the decrease of the average height of the microroughnesses of the lateral surface by $54 \%$ and of the top surface - by $65 \%$ (at $P=2.5 \mathrm{~W} ; V=2.5 \mathrm{~mm} / \mathrm{s}$ ), as compared to an unprocessed specimen, predetermines a reduction of the rate of wear of the lateral and top surface, as compared to the unprocessed specimens, 39 times and 17 times, respectively. 


\section{Priedai $^{3}$}

A priedas. Geležies lydiniams legiruoti dažniausiai naudojami legiruojantieji elementai

B priedas. A-D eksperimentinių tyrimų technologinių parametrų reikšmès

C priedas. Autoriaus sąžiningumo deklaracija

D priedas. Bendraautorių sutikimai teikti publikacijų medžiagą disertacijoje

E priedas. Autoriaus mokslinių publikacijų disertacijos tema kopijos

${ }^{3}$ Priedai pateikiami pridètoje kompaktinèje plokštelèje. 
Vladislav MARKOVIČ

DAUGIAFUNKCIỤ PAVIRŠIỤ

IŠ GELEŽIES-NIKELIO-KOBALTO MILTELINIŲ MEDŽIAGŲ FORMAVIMAS IR TYRIMAS

Daktaro disertacija

Technologijos mokslai, medžiagų inžinerija (08T)

THE FORMATION AND INVESTIGATION OF MULTIFUNCTIONAL SURFACES FROM IRON-NICKEL-COBALT POWDER MATERIALS

Technological Sciences, Materials Engineering (08T)

201807 13. 10,0 sp. I. Tiražas 20 egz.

Vilniaus Gedimino technikos universiteto

leidykla "Technika“"

Saulètekio al. 11, 10223 Vilnius,

http://leidykla.vgtu./t

Spausdino Bl UAB „Baltijos kopija“

Kareivių g. 13B, 09109 Vilnius 